1) Fo

ar

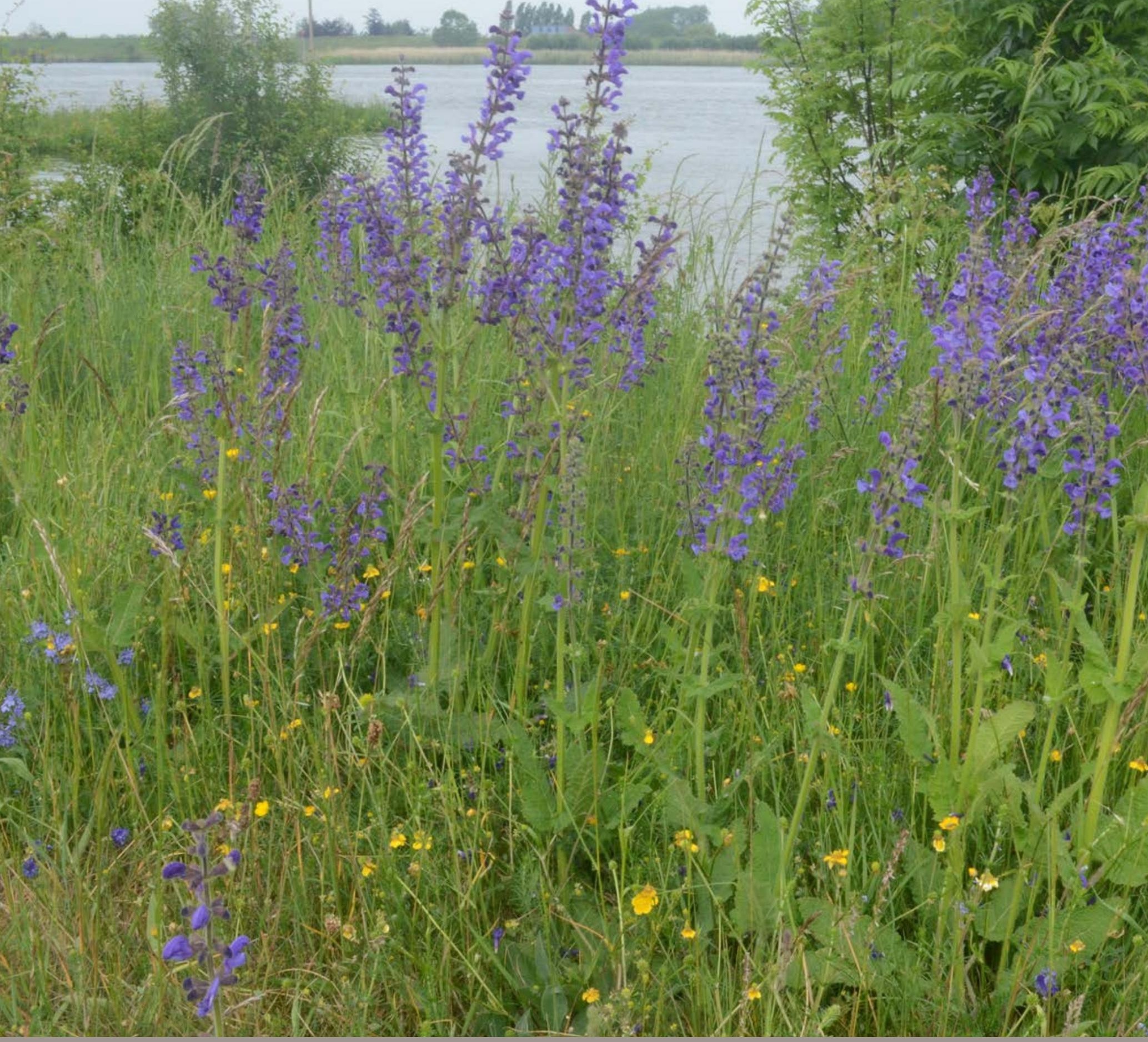

\title{
Habitatrichtlijnrapportage 2019: Annex D Habitattypen
}

Achtergronddocument

J.A.M. Janssen (red.), R.J. Bijlsma (red.), G.H.P. Arts, M.J. Baptist, S.M. Hennekens, B. de Knegt, T. van der Meij, J.H.J. Schaminée, A.J. van Strien, S. Wijnhoven \& T.J.W. Ysebaert 

Habitatrichtlijnrapportage 2019: Annex D Habitattypen 
Dit Technical report is gemaakt conform het Kwaliteitsmanagementsysteem (KMS) van de unit Wettelijke Onderzoekstaken Natuur \& Milieu, onderdeel van Wageningen University \& Research.

De WOT Natuur \& Milieu voert wettelijke onderzoekstaken uit op het beleidsterrein natuur en milieu. Deze taken worden uitgevoerd om een wettelijke verantwoordelijkheid van de Minister van Landbouw, Natuur en Voedselkwaliteit (LNV) te ondersteunen. We zorgen voor rapportages en data voor (inter)nationale verplichtingen op het gebied van agromilieu, biodiversiteit en bodeminformatie, en werken mee aan producten van het Planbureau voor de Leefomgeving zoals de Balans van de Leefomgeving.

\section{Disclaimer WOt-publicaties}

De reeks 'WOt-technical reports' bevat onderzoeksresultaten van projecten die kennisorganisaties voor de unit Wettelijke Onderzoekstaken Natuur \& Milieu hebben uitgevoerd.

WOt-technical report 171 is het resultaat van een onderzoeksopdracht van en gefinancierd door het ministerie van Landbouw, Natuur en Voedselkwaliteit (LNV). 


\title{
Habitatrichtlijnrapportage 2019: Annex D Habitattypen
}

\author{
Achtergronddocument
}

John Janssen (red.) ${ }^{1}$, Rienk-Jan Bijlsma (red. ${ }^{1}$, Gertie Arts $^{1}$, Martin Baptist ${ }^{2}$, Stephan Hennekens ${ }^{1}$, Bart de Knegt $^{1}$, Tom van der Meij ${ }^{3}$, Joop Schaminée ${ }^{1}$, Arco van Strien ${ }^{3}$, Sander Wijnhoven ${ }^{4}$, Tom Ysebaert ${ }^{2}$

1 Wageningen Environmental Research

2 Wageningen Marine Research

3 Centraal Bureau voor de Statistiek

4 Ecoauthor

Projectnummer WOT-04-009-034.04

Wettelijke Onderzoekstaken Natuur \& Milieu

Wageningen, april 2020

wot-technical report 171

ISSN 2352-2739

DOI $10.18174 / 514490$ 


\section{Referaat}

Janssen, J.A.M. (red.), R.J. Bijlsma (red.), G.H.P. Arts, M.J. Baptist, S.M. Hennekens, B. de Knegt, T. van der Meij, J.H.J. Schaminée, A.J. van Strien, S. Wijnhoven, T.J.W. Ysebaert (2020). Habitatrichtlijnrapportage 2019: Annex D Habitattypen. Achtergronddocument. Wettelijke Onderzoekstaken Natuur \& Milieu, WOttechnical report 171.97 blz.; 3 fig.; 12 tab.; 53 ref; 8 Bijlagen.

Dit document beschrijft de rapportage van Nederland in 2019 over de habitattypen van Natura 2000 voor de periode 2013-2018. Deze rapportage wordt zes-jaarlijks uitgevoerd als verplichting onder de Europese Habitatrichtlijn (Artikel 17). Voor alle 52 habitattypen is de staat van instandhouding (SvI) vastgesteld volgens een door de Europese Commissie voorgeschreven methode. Het rapport beschrijft uitgangspunten, data en methoden van de beoordeling van de parameters van de SvI: verspreidingsgebied, oppervlakte, structuur \& functie (S\&F) en toekomstperspectief. Het verspreidingsgebied blijkt weinig veranderd ten opzichte van de rapportage in 2013. De oppervlaktes zijn voor de meeste habitattypen gerapporteerd zoals in 2013 omdat er geen betrouwbare, nieuwe gegevens voorhanden waren. De methodiek van beoordeling van S\&F is sterk aangepast vanwege het gewijzigde rapportageformat en om beter aan te sluiten op data uit langlopende monitoring. Voor het toekomstperspectief heeft de Europese Commissie een nieuwe methodiek voorgeschreven. Het rapport signaleert tevens een aantal verbeterpunten voor de rapportage.

Trefwoorden: Natura 2000, Habitatrichtlijn, habitattypen, Europese rapportage, staat van instandhouding

\section{Abstract}

Janssen, J.A.M. (ed.), R.J. Bijlsma (ed.), G.H.P. Arts, M.J. Baptist, S.M. Hennekens, B. de Knegt, T. van der Meij, J.H.J. Schaminée, A.J. van Strien, S. Wijnhoven, T.J.W. Ysebaert (2020). Habitats Directive Report 2019: Annex D Habitat Types - Background Document. Statutory Research Tasks Unit for Nature \& the Environment, WOt Technical Report 171. 97 p.; 3 fig.; 12 tab.; 53 ref; 8 Annexes

This document describes the concepts, data and methods used in the 2019 report (under Article 17 of the Habitats Directive) on the conservation status of habitat types for the parameters range, area, structure and functions, and future prospects. The ranges of nearly all habitat types have not changed. No reliable, updated data on area were available for most habitat types. The methodology for assessing structure and functions has been thoroughly revised to accommodate long-term monitoring data and meet the new reporting formats. The European Commission has also introduced a new method for assessing future prospects. The report presents the results and indicates where the methods and data can be improved.

Keywords: Natura 2000, Habitats Directive, habitat types, Article 17 report, conservation status

Foto omslag: John Janssen

\author{
Wageningen Environmental Research \\ Postbus 47, 6700 AA Wageningen \\ Tel: (0317) 480700 \\ e-mail: john.janssen@wur.nl
}

\author{
Wageningen Marine Research \\ Postbus 571780 AB Den Helder \\ Tel: (0317) 480900 \\ e-mail: imares@wur.nl
}

Wettelijke Onderzoekstaken Natuur \& Milieu (unit binnen de rechtspersoon Stichting Wageningen Research), Postbus 47, 6700 AA Wageningen, T 03174854 71, info.wnm@wur.nl, www.wur.nl/wotnatuurenmilieu.

WOT Natuur \& Milieu is onderdeel van Wageningen University \& Research.

Dit rapport is gratis te downloaden van https://doi.org/10.18174/514490 of op www.wur.nl/wotnatuurenmilieu. De WOT Natuur \& Milieu verstrekt geen gedrukte exemplaren van rapporten.

- Overname, verveelvoudiging of openbaarmaking van deze uitgave is toegestaan mits met duidelijke bronvermelding.

- Overname, verveelvoudiging of openbaarmaking is niet toegestaan voor commerciële doeleinden en/of geldelijk gewin.

- Overname, verveelvoudiging of openbaarmaking is niet toegestaan voor die gedeelten van deze uitgave waarvan duidelijk is dat de auteursrechten liggen bij derden en/of zijn voorbehouden.

Wettelijke Onderzoekstaken Natuur \& Milieu aanvaardt geen aansprakelijkheid voor eventuele schade voortvloeiend uit het gebruik van de resultaten van dit onderzoek of de toepassing van de adviezen. 


\section{Woord vooraf}

De Habitatrichtlijn en Vogelrichtlijn vormen de Europese Natuurbeschermingswetten die samen ook wel Natura 2000 worden genoemd. Deze wetten zijn in het leven geroepen om de sterke achteruitgang van biodiversiteit in Europa te stoppen, en de natuur te herstellen waar dat mogelijk is. Voor de Habitatrichtlijn moet elke Europese lidstaat om de zes jaar rapporteren. Een belangrijk onderdeel van deze rapportage is het ecologische deel. Hierin geven lidstaten aan in hoeverre de doelen van de richtlijn, het in een gunstige staat van instandhouding brengen van alle beschermde habitattypen en soorten, gehaald worden. Dit rapport beschrijft de actuele staat van instandhouding voor habitattypen, waarbij gedetailleerd wordt beschreven welke onderdelen naar Europa gerapporteerd dienen te worden en welke achterliggende gegevens en methoden hiervoor in Nederland zijn gebruikt.

Aan de rapportage hebben, naast de diverse auteurs, veel andere mensen meegewerkt. Het project stond onder begeleiding van een commissie bestaande uit afgevaardigden van het Ministerie van LNV (Wilmar Remmelts, Annemiek Adams), het Ministerie van I\&W (Suzanne Stuijfzand), provincies en BIJ12 (Marion Pross, Peter van der Molen, Ellen Meulman, Fons Koomen), het CBS (Arco van Strien), de Vlinderstichting (Gerdien Bos, Chris van Swaay), SOVON (André van Kleunen) en WENR (Sandra Clerkx, Anne Schmidt, Rienk-Jan Bijlsma, John Janssen). Meinte Engelmoer en Frank Bos (provincies) waren agenda-lid. De voorlopige resultaten van de rapportages zijn begin 2019 tijdens een drietal workshops gepresenteerd en bediscussieerd met afgevaardigden van provincies, rijksoverheid, terreinbeherende organisaties en andere belanghebbenden.

Met deze rapportage over de habitattypen van de Habitatrichtlijn hopen wij opnieuw een stap gezet te hebben in de richting van navolgbare resultaten die zijn gebaseerd op een stabiele stroom van data uit natuurmonitoringsprojecten. Er zijn in het hele proces nog wel enkele verbeteringen te zetten, zoals wordt toegelicht in het rapport. Ook ligt er nog een hele uitdaging om de staat van instandhouding van de habitattypen te verbeteren.

John Janssen \& Rienk-Jan Bijlsma

Wageningen, april 2020 



\section{Inhoud}

$\begin{array}{ll}\text { Woord vooraf } & 5\end{array}$

$\begin{array}{ll}\text { Samenvatting } & 9\end{array}$

$\begin{array}{ll}\text { Summary } & 13\end{array}$

1

$\begin{array}{ll}\text { Inleiding } & 17\end{array}$

2

$\begin{array}{ll}\text { Rapportage Verspreidingsgebied } & 19\end{array}$

$\begin{array}{lll}2.1 & \text { Format } & 19\end{array}$

$\begin{array}{ll}2.2 & \text { Data en werkwijze mariene typen }\end{array}$

$\begin{array}{lll}2.3 & \text { Data en werkwijze terrestrische typen } & 20\end{array}$

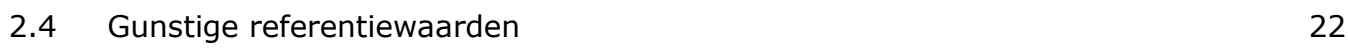

2.5 Resultaten $\quad 22$

$\begin{array}{lll}2.6 & \text { Discussie } & 22\end{array}$

3

$\begin{array}{ll}\text { Rapportage Oppervlakte } & 25\end{array}$

3.1 Format $\quad 25$

3.2 Data en werkwijze mariene habitattypen $\quad 25$

$\begin{array}{lll}3.3 & \text { Data en werkwijze terrestrische habitattypen } & 25\end{array}$

$\begin{array}{ll}3.4 & \text { Gunstige referentiewaarden }\end{array}$

$\begin{array}{lll}3.5 & \text { Resultaten } & 26\end{array}$

$\begin{array}{lll}3.6 & \text { Discussie } & 27\end{array}$

$4 \quad$ Rapportage Structuur en Functie (S\&F) $\quad 29$

$\begin{array}{lll}4.1 & \text { Format } & 29\end{array}$

$\begin{array}{lll}4.2 & \text { Uitgangspunten werkwijze } & 29\end{array}$

4.2.1 S\&F in strikte zin 29

4.2.2 Typische soorten 30

4.2.3 Eindoordeel Structuur \& Functie inclusief Typische soorten 30

4.3 Werkwijze en data mariene typen 30

4.3.1 Kwelders $(1310,1330) \quad 32$

4.3.2 Aquatische habitattypen (3110-3260) 34

$\begin{array}{lll}4.4 & \text { Werkwijze en data soortenrijke terrestrische typen } & 38\end{array}$

4.4.1 S\&F in strikte zin ('NDFF-methode') 38

4.4.2 Typische soorten $\quad 41$

4.5 Overige analyses ten behoeve van rapportage S\&F $\quad 42$

4.5.1 Analyse S\&F voor soortenarme, terrestrische typen $\quad 42$

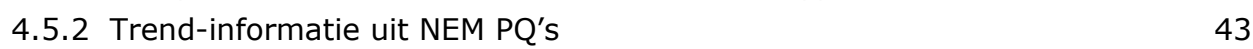

4.5.3 Analyse S\&F met NBI-gegevens (bossen) 47

$\begin{array}{lll}4.6 & \text { Resultaten } & 50\end{array}$

$\begin{array}{lll}4.7 & \text { Discussie } & 50\end{array}$

$5 \quad$ Rapportage Toekomstperspectief $\quad 55$

5.1 Format $\quad 55$

5.2 Data en werkwijze $\quad 55$

5.3 Resultaten \& Discussie $\quad 55$

$\begin{array}{lc}\text { Literatuur } & \mathbf{5 7}\end{array}$ 
Bijlage 1 Evaluatie-matrix voor beoordeling staat van instandhouding habitattypen 63

Bijlage 2 Instructies voor invullers van het "reporting format" voor Annex I habitattypen

Bijlage 3 Criteria voor toedeling van opnamen aan habitattypen t.b.v. verspreidingskaarten

Bijlage 4 Resultaten verspreidingskaarten habitattypen

Bijlage 5 Verschillen in landelijke oppervlakte habitattypen in kaarten uit 2013 en 2017

Bijlage 6 Schema beoordeling S\&F

Bijlage 7 Karakteristieke soorten vaatplanten en mossen per habitattype

Bijlage 8 Resultaten S\&F: NDFF-methode, Typische soorten en NBI-methode 


\section{Samenvatting}

Dit technical report geeft een toelichting op de Europese rapportage van Nederland in 2019 over de habitattypen van Natura 2000. Het is een achtergrondrapport waarin de gebruikte uitgangspunten, data en methoden voor de rapportage worden beschreven.

De Europese rapportage wordt zes-jaarlijks door alle Europese lidstaten uitgevoerd als verplichting onder de Europese Habitatrichtlijn (Artikel 17). De resultaten worden gepubliceerd op de EIONET website van het European Environmental Agency. In 2019 is voor de vierde keer gerapporteerd, waarbij voor de derde keer een beoordeling van de staat van instandhouding is gegeven. De rapportage van 2019 heeft betrekking op de periode 2013-2018 en betreft - naast de habitattypen ook een vergelijkbare rapportage over beschermde soorten van de Habitatrichtlijn, waarover een apart achtergronddocument wordt uitgebracht. Voor de huidige rapportage zijn vanuit Europa aangepaste instructies opgesteld (Reporting under Article 17 of the Habitat Directive. Explanatory Notes and Guidelines for the period 2013-2018).

In dit WOt-technical report wordt toegelicht welke ecologische gegevens per habitattype zijn gerapporteerd en welke data en methoden hierbij zijn gebruikt. Uiteindelijk heeft per habitattype een beoordeling van de staat van instandhouding plaatsgevonden, volgens een door de Europese Commissie voorgeschreven beoordelingsmatrix (bijlage 1). De vier parameters van de staat van instandhouding (verspreidingsgebied, oppervlakte, structuur \& functie inclusief typische soorten, toekomstperspectief) worden afzonderlijk beoordeeld als goed (groen), matig ongunstig (oranje), zeer ongunstig (rood) of onbekend (grijs), wat leidt tot een eindoordeel op basis van het one out all out principe. De uitgevoerde beoordelingen van deze parameters worden in het rapport afzonderlijk besproken, waarbij wordt aangegeven in hoeverre de methodes en resultaten afwijken van de rapportage van zes jaar geleden. Tevens wordt per parameter bediscussieerd waar nog verbeterpunten zijn voor de volgende rapportage in 2025. Opmerkelijke veranderingen ten opzichte van de rapportage van zes jaar geleden worden toegelicht.

Bij het verspreidingsgebied is relatief weinig veranderd ten opzichte van de rapportage in 2013. Alleen voor H3110 (Zeer zwak gebufferde vennen) is sprake van een afname van het areaal in ons land. Voor drie habitattypen is de staat van instandhouding van het verspreidingsgebied gunstiger beoordeeld dan in de vorige rapportage, op basis van een correctie van de data van de vorige rapportage $(3140,6410)$ en op basis van een aangepaste definitie (6510). Voor het habitattype 9120 (Beuken-eikenbossen) is deze beoordeling negatiever, als gevolg van een correctie in de data die gebruikt zijn voor de verspreiding. Mogelijk moet de gunstige referentiewaarde voor het verspreidingsgebied van dit habitattype ook worden aangepast.

De gerapporteerde oppervlaktes zijn voor de meeste habitattypen niet anders dan in de vorige rapportage, aangezien er geen betrouwbare, nieuwe gegevens voorhanden waren. De datastroom van vegetatie- en habitatkaarten is nog niet geschikt voor het 6-jaarlijks rapporteren van aangepaste landelijke oppervlaktes van habitattypen. Het zal voor de volgende rapportage zaak zijn om deze gegevensstroom over de oppervlakte veel beter georganiseerd te krijgen, waarbij een belangrijke rol is weggelegd voor de Nationale Databank Vegetatie- en Habitatkaarten (NDVH). Voor een klein aantal habitattypen zijn wel nieuwe oppervlaktes gerapporteerd. Voor twee mariene habitattypen (1110 en 1170) en voor habitattype 7220 (Kalktufbronnen) is een aangepaste oppervlakte gerapporteerd op basis van betere gegevens. Van de kweldertypen 1310 en 1330 zijn wel elke zes jaar nauwkeurige, recente gegevens voorhanden: beide typen zijn enigszins uitgebreid in oppervlakte. Verder zijn voor vier habitattypen positieve en voor drie habitattypen negatieve trends gerapporteerd, op basis van expert-kennis en literatuurgegevens, zonder dat nieuwe waarden voor de oppervlakte zijn aangegeven. Habitattype 9120 (Beuken-eikenbossen) is als enige habitattype wat betreft de oppervlakte negatiever beoordeeld dan in de vorige rapportage, als gevolg van een 
aangepaste gunstige referentiewaarde (Favourable Reference Value), aansluitend bij de laatste richtlijnen vanuit Europa.

Ten opzichte van de rapportage uit 2013 is de methodiek van beoordeling van structuur \& functie (S\&F) verder doorontwikkeld. Evenals voor eerdere rapportageperioden worden S\&F in strikte zin (d.w.z. exclusief Typische soorten) en Typische soorten afzonderlijk beoordeeld en vervolgens gecombineerd tot een eindoordeel voor de Staat van Instandhouding. Voor dit onderdeel van de rapportage worden vanuit Europa aanvullende gegevens gevraagd ten opzichte van eerdere rapportages. Nieuw is het rapporteren van de oppervlakte habitattype met een goede, een niet-goede en onbekende S\&F, alsmede het rapporteren van de trend in oppervlakte met goede S\&F. Deze beide indicatoren vereisten een nieuwe werkwijze voor de beoordeling van S\&F in strikte zin.

Uitgangspunt van de nieuwe werkwijze voor de beoordeling van S\&F in strikte zin was dat er sprake moet zijn van (i) een navolgbare (reproduceerbare) methode die (ii) zo veel mogelijk wordt gevoed met bestaande monitoring-data, en wel (iii) data waarvan verwacht wordt dat die ook in de toekomst langdurig zal worden ingewonnen. Bovendien (iv) verschilt de methode van beoordeling tussen groepen van habitattypen. Hierbij zijn de volgende hoofdgroepen onderscheiden:

- Mariene habitattypen (1110 t/m 1170), waarvoor is aangesloten bij twee verschillende gegevenssets. Voor de Noordzee-typen (1110 en 1170, inclusief 1110A) wordt de benthos monitoring volgens de Benthische Indicator Soorten Index (BISI) van de Kaderrichtlijn Marien (KRM) gebruikt. Voor de typen in de overgangswateren $(1130,1140,1160)$ zijn in principe monitoringsgegevens van de Kaderrichtlijn Water (KRW) gebruikt.

- $\quad$ Buitendijkse kwelder(sub)typen (1310 en 1330), waarvoor gebruik is gemaakt van een KRWmaatlat waarmee wordt beoordeeld in hoeverre er in een gebied een evenwichtige opbouw is van de verschillende zones op de kwelder. Deze maatlat is gebaseerd op data van het VEGWAD monitoringsprogramma van Rijkswaterstaat.

- $\quad$ Aquatische habitattypen (3110 t/m 3260), waarvoor in principe ook is aangesloten bij de KRW-monitoring, maar dan voor de zoete wateren. Uiteindelijk is alleen voor de habitattypen 3140 (Kranswierwateren) en 3150 (Meren met krabbenscheer en fonteinkruiden) de rapportage voor de Habitatrichtlijn sterk gebaseerd op deze KRW-data.

- $\quad$ Soortenrijke terrestrische habitattypen, waarvoor een nieuwe werkwijze is ontwikkeld die gebruik maakt van verspreidingsgegevens in de Nationale Databank Flora en Fauna (NDFF). De achtergrond van deze werkwijze is dat het goed functioneren van een habitattype als leefgebied voor karakteristieke soorten blijkt uit de soortensamenstelling. De status en trend van zogenaamde karakteristieke soorten geeft aan of S\&F op orde zijn, waarbij verspreidingsgegevens uit de NDFF als gegevensbron dienen. Op de schaal van kilometerhokken (waar het habitattype aanwezig is) is geanalyseerd hoeveel karakteristieke soorten zijn aangetroffen in een periode van zes jaar, en wat de trend in aantal soorten is tussen periodes. Vooralsnog is dit alleen op basis van plantensoorten gedaan. Soortenrijke voorkomens van habitattype met overwegend stabiele of positieve trend in de aanwezigheid van karakteristieke soorten worden beschouwd als habitattype in goede conditie. Relatief soortenarme voorkomens van habitattype met overwegend negatieve trend in aanwezigheid van karakteristieke soorten worden beschouwd als habitattype in niet-goede conditie. Deze werkwijze leidt tot groene, rode en overige (oranje) aanduidingen van km-hokken met habitattype. De fracties km-hokken met habitattype in goede en niet-goede conditie worden betrokken op het landelijk areaal, wat schattingen levert van de landelijke oppervlakten habitattype in goede en niet-goede conditie. Het eindoordeel S\&F in strikte zin volgt uit drempelwaarden gebruikt voor percentages km-hokken gunstig, matig ongunstig en zeer ongunstig, zoals ook gebruikt bij de vorige rapportage. Door deze analyse voor drie perioden uit te voeren, wordt ook een inschatting van de trend in oppervlakte habitattype in goede conditie verkregen.

- $\quad$ Overige soortenarme, terrestrische habitattypen waarvoor geen geschikte gegevens en beoordelingsmethodiek voor S\&F voorhanden zijn. Dit betreft 15 typen, waaronder 2160 (Duindoornstruwelen), 2320 (Binnenlandse kraaiheibegroeiingen) en 7210 (Galigaanmoerassen). Deze zijn beoordeeld met expert-kennis en/of met de in 2013 gebruikte opschaling van beoordelingen op gebiedsniveau (SDF: Standaard Dataformulier). Voor de meeste van deze typen is het oppervlakte met goede en niet-goede condities als onbekend gerapporteerd. 
De bepaling van de aandelen oppervlakte habitattype in goede en niet-goede staat geeft aanleiding tot een voorlopige beoordeling van S\&F in strikte zin, waarbij afhankelijk van de hoofdgroep dus verschillende data zijn gebruikt. Naast deze primaire beoordeling is voor enkele habitattypen gebruik gemaakt van andere langlopende datastromen, met name NEM-PQ's en NBI:

- $\quad$ Permanente proefvlakken uit het Landelijk Meetnet Flora (LMF) van het Netwerk Ecologische Monitoring (NEM) zijn gebruikt om trends te berekenen in diverse indicatoren, zoals verdroging, verzuring, eutrofiëring, successie (aandeel pioniersoorten, openheid, aandeel struweel/bos) en soortenrijkdom. Deze trend-gegevens zijn door het CBS automatisch berekend voor in totaal 41 indicatoren voor een selectie aan PQ's.

- $\quad$ Meetpunten uit de Nederlandse Bosinventarisatie (NBI) en voorganger Meetnet Functievervulling (MFV). Voor habitattypen bos (van de habitatkaart) die voldoende zijn vertegenwoordigd in de steekproef is de gemiddelde hoeveelheid dood hout totaal $\left(\mathrm{m}^{3} / \mathrm{ha}\right.$ ) gebruikt bij de beoordeling van S\&F, namelijk voor 2180 (Duinbossen), 9110 (Veldbiesbeukenbossen), 9120 (Beuken-eikenbossen) en 9160B (Eiken-haagbeukenbossen, heuvelland) en 9190 (Oude eikenbossen). Hiertoe zijn drempelwaarden ontleend aan internationale literatuur. De hoeveelheden dood hout blijken laag (U1; 9120,9190,9160B) tot zeer laag (U2; 2180, 9110). Trends (NBI ten opzichte van MFV) zijn stabiel $(9110,9160 B)$ tot positief $(2180,9120,9190)$.

Deze aanvullende beoordelingen zijn gebruikt voor het versterken of eventueel aanpassen van de voorlopige beoordeling van S\&F in strikte zin. Voor het habitattype 7230 (Kalkmoerassen), dat relatief goed vertegenwoordig is in het NEM PQ-netwerk, waren deze gegevens doorslaggevend bij de beoordeling van de S\&F trend.

Naast S\&F in strikte zin zijn Typische soorten beoordeeld zoals bij de vorige rapportage, dus op basis van de meest recente landelijke Rode Lijst-status. Voor enkele soorten is deze status aangepast met actuele informatie aan de hand van de door het CBS ontwikkelde Virtuele Rode Lijst.

Het eindoordeel $S \& F$ is voor alle habitattypen toegelicht indien dit niet zonder meer volgt uit de beoordelingen van S\&F in strikte zin en Typische soorten. Doordat voor de meeste habitattypen gebruik is gemaakt van een andere methode voor de beoordeling van S\&F in strikte zin, kan daardoor ook het eindoordeel zijn veranderd ten opzichte van de vorige rapportage.

Samengevat zijn de volgende veranderingen in de staat van instandhouding van S\&F gerapporteerd ten opzichte van 2013:

- Van matig ongunstig naar zeer ongunstig: H1110 (Permanent overstroomde zandbanken), H1170 (Riffen), H6120 (Stroomdalgraslanden), H6510 (Glanshaver- en Vossenstaarthooilanden) en H9190 (Oude eikenbossen)

- Van zeer ongunstig naar matig ongunstig: H2130 (Grijze duinen), H6110 (Pionierbegroeiingen op rotsbodem) en $\mathrm{H} 6410$ (Blauwgraslanden)

- Van matig ongunstig naar gunstig: H1310 (Zilte pionierbegroeiingen), H2120 (Witte duinen), H2140 (Duinheiden met kraaihei), H2170 (Kruipwilgstruwelen) en H3270 (Slikkige rivieroevers).

De werkwijze voor beoordeling van de laatste parameter, het toekomstperspectief, is in de Reporting Guidelines veel strikter voorgeschreven dan in eerdere rapportages. In feite geeft het toekomstperspectief alleen een andere beoordeling dan de voorgaande drie parameters indien de verwachting is dat binnen twee rapportageperiodes de staat van instandhouding van een parameter sterk zal verbeteren of verslechteren. Voor slechts drie habitattypen (H1310 Zilte pionierbegroeiingen, H3150 Meren met krabbenscheer en fonteinkruiden, en H7220 Kalktufbronnen) is gerapporteerd dat het toekomstperspectief zodanig slechter is dan de eerdere parameters, dat deze vierde parameter doorslaggevend is voor het eindoordeel. De hierbij gesignaleerde doorslaggevende bedreigingen zijn respectievelijk klimaatverandering, doorgaande negatieve invloed van invasieve exoten (kreeften) en doorgaande aanzienlijke nitraatuitspoeling.

De totale staat van instandhouding van 6 (11\%) habitattypen is gunstig, van 18 (35\%) ongunstig, en van $28(54 \%)$ zeer ongunstig. In totaal 15 habitattypen vertonen een positieve trend over de rapportageperiode, 21 een stabiele trend, 13 een negatieve trend en bij 3 habitattypen is de trend 
onbekend. Ten opzichte van de vorige rapportage (2007-2012) is het aantal typen in gunstige staat toegenomen, maar dit geldt ook voor het aantal typen met een zeer ongunstige staat van instandhouding.

Voor alle gebruikte databronnen en methoden is in dit rapport aangegeven waar verbeterpunten bestaan die doorgevoerd zouden moeten worden voor de volgende rapportage. 


\section{Summary}

This technical report describes the Netherlands Article 17 Habitats Directive Report 2019 on the habitat types in the Natura 2000 protected area network. It provides the background to the principles, data and methods used.

Article 17 of the Habitats Directive obliges all EU Member States to produce progress reports every six years. The results are made public through the EIONET website of the European Environmental Agency. In 2019 the Netherlands reported for the fourth time and it is the third time that an assessment of conservation status was given for the habitat types. The 2019 report covers the period 2013-2018 and contains - besides the reporting on habitat types - a similar report on the conservation status of protected species listed in the Annexes of the Habitat Directive. The species reporting is explained in a separate WOt technical report. For the 2019 report the European Commission prescribed adapted reporting formats and guidelines, as set out in Reporting under Article 17 of the Habitat Directive. Explanatory Notes and Guidelines for the period 2013-2018.

This Wot-technical report explains which data and methods were used to compile the report and assess the conservation status according to the guidelines in the assessment matrix provided by the European Commission (Appendix 1). Four parameters of conservation status - range, area, structure and functions, future prospects - are assessed separately as favourable (green), unfavourableinadequate (amber), unfavourable-bad (red) or unknown (grey), leading to a conclusion following the one-out-all-out principle. A description is given of how the methods and results differ from the previous Article 17 report six years ago. Possible improvements in the methods and data used for the 2025 report are discussed for each parameter.

The range is largely based on (i) vegetation relevés (from the Dutch Vegetation Database) assigned to habitat types using specific criteria and (ii) habitat type maps for the Natura 2000 sites. The range did not change much for most habitat types when using an 'uncertainty interval' of $10 \%$. The only habitat range to decrease by more than $10 \%$ was habitat type 3110 (Oligotrophic waters containing very few minerals of sandy plains, Littorelletalia uniflorae), which was already very small. For three habitat types the assessment of the conservation status of the range was more positive than in the previous reporting period. For two of these habitat types (3140 and 6410) this was due to a correction of the data used in the last report and for the third (6510) it was due to a slightly changed definition of the habitat type. The assessment was more negative than six years ago for habitat type 9120 (Atlantic acidophilous beech forests with Ilex and sometimes also Taxus in the shrublayer) due to improved data on the distribution of the habitat type. The favourable reference value for the range may have to be corrected as well.

For most habitat types the reported areas did not differ from the reported values six years ago. The reason is that no reliable new area data were available for most habitat types. A new national database of vegetation maps and habitat maps has been built to fill this data gap in future. A change in area was reported for only two marine habitat types (1110 and 1170) and for habitat type 7220 (Petrifying springs with tufa formation, Cratoneurion), based on the availability of better data. Detailed and recent data are available every six years from the Rijkswaterstaat monitoring programmes for the salt marsh habitat types 1310 and 1330: the area of both types increased slightly. Positive trends were reported for four habitat types and negative trends for three habitat types based on expert knowledge and the literature, in the absence of no new area values. The assessment of the conservation status for area was more negative than in the previous report only for habitat type 9120 (Atlantic acidophilous beech forests with Ilex and sometimes also Taxus in the shrublayer) as a result of a changed favourable reference area.

The method used to assess structure and functions (S\&F) was very different from that used for the 2013 report. As in previous reports, we carried out an assessment of S\&F in the strict sense (excluding 
typical species) and a separate assessment of the typical species. Both assessments were combined into a final 'broad' assessment of the conservation status for S\&F.

The European Commission has provided new instructions for this part of the report. In 2019 the areas of habitat with 'good condition', 'not-good condition' and unknown condition had to be reported. Also the trend in area of habitat with good condition had to be reported. These indicators required the development of a new method for assessing S\&F in a strict sense.

The principles of the new approach are (i) the method is repeatable, (ii) the method is based on existing monitoring data, (iii) data gathering is expected to continue over the long term, and (iv) assessment methods differ between main groups of habitat types. The main groups of habitat types and the monitoring data used for assessing them are given below:

- Marine habitat types (1110 to 1170) - different sets of monitoring data. For the habitat types of the open sea $(1110,1170)$, the Bentic Indicator Species Index (BISI), developed for reporting for the Marine Framework Directive, was used. For the habitat types in coastal water $(1130,1140,1160)$, monitoring data from the Water Framework Directive were used.

- $\quad$ Salt marshes (1310 and 1330) - monitoring data and assessments for the Water Framework Directive. An assessment was made of the degree to which certain areas have a balanced zonation in the salt marsh, based on the method developed in Rijkswaterstaat's VEGWAD monitoring programme.

- $\quad$ Aquatic habitat types (3110 to 3260) - monitoring data from the Water Framework Directive, but from freshwater areas. In the 2019 report these data were good and complete enough to carry out an assessment of S\&F only for habitat types 3140 (Hard oligo-mesotrophic waters with benthic vegetation of Chara spp.) and 3150 (Natural eutrophic lakes with Magnopotamion or Hydrocharition-type vegetation).

- $\quad$ Species-rich terrestrial habitat types - a new method was developed using species distribution data from the National Databank Flora \& Fauna (NDFF). The concept behind this method is that a habitat type is considered to have favourable structure and functions if it forms a suitable biotope for its characteristic species, as indicated by the species composition derived from distribution data from the NDFF. Both the status and the trend of characteristic species indicate whether the conditions (S\&F) are favourable. The assessment was carried out at the scale of kilometre grids. In those grids in which the habitat type occurs, the number of characteristic species observed within a period of six years and the trend in the number of observed species compared with the previous six year-year period were recorded. For the 2019 report this analysis was carried out for plant species only. In relatively species-rich grids with stable or increasing numbers of characteristic species, the habitat type was considered to be in good condition. In relatively species-poor grids with stable or decreasing numbers of characteristic species, the habitat type was considered to be in not-good condition. This analysis provided green, red and amber (other grids) scores for all grid cells in which a habitat type is present, as well as grids with unknown scores (grey) where no or limited data were available. The proportion of grid cells in which the habitat type is in good condition was related to the total area of the habitat in the country, which resulted in estimates of the area of a habitat with favourable S\&F. In the same way, the area of the habitat with unfavourable S\&F and unknown S\&F could be reported. We carried out this analysis for three periods, which also provided the trend in the area of habitat type with favourable S\&F. The final assessment of the conservation status for S\&F was based on the percentages of grid cells with favourable, unfavourable-inadequate and unfavourable-bad status, using thresholds which have been applied in other analyses and in the previous reporting period as well.

- $\quad$ Other, species-poor terrestrial habitat types - no or limited suitable data and methodology were available. These 15 types, including 2160 (Dunes with Hippophae rhamnoides), 2320 (Dry sand heaths with Calluna and Empetrum nigrum) and 7210 (Calcareous fens with Cladium mariscus) were assessed using expert knowledge and/or upscaling of the assessments of conservation status at the site level (in the Standard Data Forms). Alternatively, for most of these habitat types the complete area has been reported to have unknown conditions.

The analysis of the proportions of the habitat area with a good, not-good and unknown condition results in a preliminary assessment of S\&F in a strict sense, which is based - as explained - on different methodologies, depending on the main group in which a habitat type fits. 
Besides this primary assessment, for several habitat types we used additional, long-term monitoring data, especially from a national network of permanent plots (NEM) and the Dutch Forest Inventory (NBI):

- $\quad$ Permanent vegetation plots from the Ecological Monitoring Network (NEM) were analysed for trends in different indicators derived from the species composition, such as desiccation, acidification, eutrophication, succession (fraction of pioneer species, vegetation cover, fraction of woody species) and species richness. In total, trend data for 41 indicators were calculated by Statistics Netherlands (CBS) using a subset of permanent plots in which the vegetation was considered to be a habitat type.

- $\quad$ For forest habitat types that are well represented in the Dutch Forest Inventory (NBI, and a previous inventory) the average amount of total (standing and lying) dead wood $\left(\mathrm{m}^{3} / \mathrm{ha}\right.$ ) was analysed and compared with thresholds from the literature. The amount of dead wood was found to be low (U1) for habitat types 9120, 9190 and $9160 \mathrm{~B}$ and very low (U2) for habitat types 2180 and 9110 . Trends in dead wood were stable $(9110,9160 \mathrm{~B})$ or positive $(2180$, 9120, 9190).

These additional analyses were used to confirm or correct the preliminary assessment of the conservation status for S\&F and its trend. Only for habitat type 7230 (Alkaline fens), which was relatively well represented by NEM plots, were these data decisive in the assessment of trends.

Besides the methods for assessing the conservation status for S\&F in a strict sense described above, the list of typical species was also used for the S\&F assessment. This analysis was carried out in the same way as in the previous reporting period, based on the most recent Red List status. For some species this was updated with information from a more recent virtual Red List (analysed by CBS). The final reported conservation status for S\&F was based on the two different analyses: in a strict sense, and based on typical species. Where these resulted in different scores for S\&F, an explanation is given of which of the scores was chosen by the expert and the reason for this decision.

For many habitat types the methodology of S\&F assessment was very different compared with previous reporting periods, and therefore in many cases the resulting scores changed. To summarise, the following changes in the conservation status for structure and functions were reported:

- from unfavourable-inadequate to unfavourable-bad: habitat types $1110,1170,6120,6510$ and 9190;

- from unfavourable-bad to unfavourable-inadequate: habitat types 2130, 6110 and 6410;

- $\quad$ from unfavourable-inadequate to favourable: 1310, 2120, 2140, 2170 and 3270.

The method for assessing the fourth parameter, future prospects, is described in much more detail in the Explanatory Notes and Guidelines than in guidelines for previous reports. Future prospects is first reported separately for all three previous parameters (range, area and S\&F). The scores differ from the assessment of the conservation status for the other parameters only if a large change in conservation status (either positive or negative) is expected within two reporting periods. The scores for these three parameters are used to calculate the overall conservation status for the future prospects parameter according to the guidelines. The overall assessment for future prospects was poorer than the conservation status of the three separate parameters for only three habitat types $(1310,3150$ and 7220$)$, and therefore for these habitat types the future prospects are decisive in the assessment of the final conservation status. The foreseen future threats for these three habitats are erosion as a result of sea level rise (1310), continuing spread of invasive non-native lobsters (3150) and continuing pollution of groundwater (7220).

The overall conservation status of $6(11 \%)$ of the habitat types is favourable, of $18(35 \%)$ of the habitat types is unfavourable-inadequate, and of $28(54 \%)$ of the habitat types is unfavourable-bad. In total, 15 habitat types showed a positive trend during the reporting period, 21 a stable trend, 13 a negative trend and for 3 habitat types the trend is unknown. Compared with the previous reporting period, the number of habitat types in a favourable conservation status increased, but the same applies to the number of habitat types that were assessed as unfavourable-bad. 
The report indicates various aspects of the data sources and methods that can be improved as a recommendation for the next reporting period. The most important of these is to improve the data gathering and analysis of the areas of habitat types. 


\section{$1 \quad$ Inleiding}

\section{Doel, format en richtlijnen}

Op grond van artikel 17 van de Habitatrichtlijn wordt elke zes jaar gerapporteerd aan de Europese Commissie in het kader van de Habitatrichtlijn. Een belangrijk onderdeel van deze rapportage vormt een beoordeling van de staat van instandhouding (SvI) van habitattypen en soorten. In 2019 wordt voor de vierde keer gerapporteerd, waarbij voor de derde keer een beoordeling van de staat van instandhouding wordt gegeven. De rapportage van 2019 heeft betrekking op de periode 2013-2018. Er wordt gerapporteerd over de habitattypen van bijlage I van de Habitatrichtlijn, de soorten van bijlagen II, IV en V, alsmede incidenteel voorkomende 'dwaalgasten'.

In 2016 is het rapportageformat beschikbaar gesteld voor de periode 2013-2018 en in 2017 zijn nadere richtlijnen gepubliceerd in de vorm van het rapport Reporting under Article 17 of the Habitat Directive. Explanatory Notes and Guidelines for the periode 2013-2018 (DG Environment 2017).

In voorliggend rapport wordt een toelichting gegeven op de gegevens en methodieken die zijn gebruikt voor de vierde rapportage (periode 2013-2018) over de habitattypen. Het betreft in totaal 52 habitattypen waarvoor in ons land beschermde gebieden zijn aangewezen. Voor deze habitattypen is de Staat van Instandhouding (SvI) gerapporteerd. De staat van instandhouding van habitattypen wordt beoordeeld op grond van vier parameters (DG Environment 2017: p. 8 Table 1):

- Verspreidingsgebied (range)

- Oppervlakte (area)

- Structuur \& functie, inclusief Typische soorten (specific structures \& functions including typical species)

- Toekomstperspectief (future prospects).

Deze parameters worden via een zogenaamde stoplichtbenadering gewogen tot een eindoordeel over de staat van instandhouding van een habitattype in de betreffende rapportageperiode. Als beoordelingscriteria worden status en trends van parameters gebruikt, maar voor "verspreidingsgebied" en "oppervlakte" ook de afstand tot zogenaamde referentiewaarden (zie evaluatiematrix in bijlage 1 ).

Ten opzichte van de vorige rapportage is de belangrijkste wijziging dat er uitgebreider gerapporteerd moet worden over de parameter "structuur \& functie". Verder zijn de standaardlijsten van drukfactoren en bedreigingen (pressures and threats) en van maatregelen (measures) aangepast, zijn er uitgebreidere richtlijnen opgesteld voor het beoordelen van de parameter "toekomstperspectief", en zijn er betere richtlijnen gekomen voor het opstellen van referentiewaarden.

Het rapportageformat is weergegeven in bijlage 2, aangevuld met richtlijnen voor de invullers van het format.

\section{Uitgangspunten rapportage 2019}

Bij de vorige twee rapportages is veel aandacht besteed aan het op orde krijgen van data-inwinning voor de parameters 'verspreidingsgebied' en 'oppervlakte'. Alhoewel hier nog steeds allerlei haken en ogen aanzitten (zie Hoofdstukken 3 en 4), is bij de voorbereiding van de huidige rapportage de nadruk gelegd op het ontwikkelen van een betere methode voor het beoordelen van structuur \& functie (zie Hoofdstuk 4). Hierbij speelt mee dat voor dit onderdeel het rapportageformat is uitgebreid ten opzicht van de vorige rapportage.

\section{Leeswijzer}

De opbouw van het rapport in hoofdstukken volgt de hierboven genoemde parameters van de Staat van Instandhouding: Hoofdstuk 2: Verspreidingsgebied 
Hoofdstuk 3: Oppervlakte

Hoofdstuk 4: Structuur \& Functie

Hoofdstuk 5: Toekomstperspectief

In bijlagen zijn het rapportageformat en overzichten van criteria, gebruikte data en werkwijzen/methoden opgenomen. 


\section{Rapportage Verspreidingsgebied}

\subsection{Format}

In het voorgeschreven format zijn de volgende gegevens de belangrijkste die moeten worden gerapporteerd:

- Kaart van het verspreidingsgebied, resolutie $10 \times 10 \mathrm{~km}^{2}$, inclusief opvulling, in ETRS coördinaten

- Oppervlakte op basis van $10 \times 10 \mathrm{~km}^{2}$-hokken (berekend op basis van RD-coördinaten)

- Trend in oppervlakte van het verspreidingsgebied

- $\quad$ Gunstige referentiewaarde (FRR)

Het betreft paragraaf 4 uit het reporting format (bijlage 2).

\subsection{Data en werkwijze mariene typen}

Voor de vijf mariene habitattypen $1110 \mathrm{t} / \mathrm{m} 1170$ is de gerapporteerde oppervlakte van het verspreidingsgebied gebaseerd op kaarten in ETRS formaat, dit in tegenstelling tot alle andere habitattypen, waarvoor kaarten in RD-coördinaten zijn gebruikt voor berekening van de oppervlakte van het verspreidingsgebied. Ook in eerdere rapportages is dit zo gedaan. Een belangrijke reden is dat gegevens van de Noordzee (voor habitattypen 1110 en 1170) in enkele gevallen alleen in ETRScoördinaten voorhanden zijn.

\section{Habitattype 1110}

Voor habitattype 1110 is het verspreidingsgebied gebaseerd op een kaart uit 2012 in $10 \times 10 \mathrm{~km}^{2}$ grid uit Bos et al. (2008), waarbij echter 5 gridcellen van de Eems-Dollard zijn weggelaten, omdat het geen $\mathrm{H} 1110$ maar H1130 betreft. In het profieldocument van H1110 uit en 2008 en 2014 (https://www.synbiosys.alterra.nl/natura2000/) is correct aangegeven dat de permanent onder water staande zandbanken in het Eems-Dollard estuarium tot habitattype 1130 behoren. De in 2013 gerapporteerde oppervlakte van het verspreidingsgebied $\left(241 \mathrm{~km}^{2}\right.$ ) bevat echter wel de 5 gridcellen van de Eems-Dollard, en ook bij het bepalen van de referentiewaarden (Bijlsma et al. 2014) wordt een onjuiste oppervlakte van $241 \mathrm{~km}^{2}$ aangehouden. Na correctie voor de Eems-Dollard, is de juiste oppervlakte van het verspreidingsgebied dus $236 \mathrm{~km}^{2}$. Deze waarde had ook in de eerdere rapportages moeten staan, wat de reden is om de trend als stabiel te rapporteren.

De gegevens uit Bos et al. (2008) zijn op de Noordzee (subtype C) gebaseerd op het gedeelte tussen de hoogwaterlijn en de -20 m dieptelijn. Voor de Doggersbank (subtype $\mathrm{D}$ ) is de $-40 \mathrm{~m}$ dieptelijn als de rand van de zandbank beschouwd, volgens de definitie in Lindeboom et al. (2005).

\section{Habitattype 1130}

Voor habitattype 1130 zijn de begrenzingen aangehouden van de buitendijkse delen van de Westerschelde (westwaarts tot de lijn Vlissingen-Breskens) en de Eems-Dollard (onderdeel van Natura 2000 -gebied Waddenzee). Het gaat in totaal om 17 gridcellen van $10 \times 10 \mathrm{~km}^{2}$.

\section{Habitattype 1140}

Voor 1140 is het verspreidingsgebied gebaseerd op de kaart uit het profielendocument uit 2014. Eén hok naast de Oosterscheldekering is toegevoegd, waarmee de totale range uitkomt op 79 gridcellen.

\section{Habitattype 1160}

Voor 1160 zijn de begrenzingen aangehouden van de buitendijkse delen van de Oosterschelde, op dezelfde wijze als in het profielendocument. De range bedraagt 11 gridellen van $10 \times 10 \mathrm{~km}^{2}$. 


\section{Habitattype 1170}

Oorspronkelijk is een habitatkaart van de Klaverbank gebaseerd op inventarisaties in de jaren 1980 en 1990, en een inventarisatie in 2002 door Van Moorsel (2003). Nieuwe gegevens zijn beschikbaar gekomen door inventarisaties van het voorkomen van concentraties van grote keien (boulders), een karakteristiek element van habitattype 1170, met side-scan sonar. Dit werd aangevuld met grondcontroles bestaande uit (i) verificatie van de aanwezigheid van epifauna gemeenschappen door middel van video, (ii) grond sampling met Hamon grabs, boxcores, trawls en dredges, en (iii) visuele waarnemingen door duikers. Aanvullende videobeelden werden in 2011 door het NIOZ gemaakt (zie Wijnhoven et al. 2013). De huidige kaart van het voorkomen van H1170 habitat en het mogelijk voorkomen op de Klaverbank (Eurofins/Aquasense et al. 2018) is gebaseerd op specifieke monitoring tussen 2013-2015 (Van den Oever et al. 2018). In het gebied van de Borkumse Stenen, zijn side-scan sonar waarnemingen uit 2009 gevalideerd in 2013 op dezelfde wijze als beschreven voor de Klaverbank (Bos et al. 2014). De gegevens zijn ruimtelijk nog niet gedetailleerd genoeg om een precieze habitat kaart te maken, zoals die beschikbaar is voor de Klaverbank.

In totaal bedraagt de range nu $3000 \mathrm{~km}^{2}$ dus één gridcel minder dan bij de vorige rapportage. Het verschil is een gevolg van de beschikbaarheid van betere gegevens.

\subsection{Data en werkwijze terrestrische typen}

Voor de verspreidingskaarten van de 47 terrestrische habitattypen zijn drie bronnen gebruikt:

\section{Habitattypenkaarten}

Voor de habitattypenkaarten uit Natura 2000-gebieden is een geaggregeerde AERIUS-versie van geheel Nederland gebruikt uit maart 2018. ${ }^{1}$ Deze habitattypenkaart is omgezet naar één database met daarin per kilometerhok het habitattype. De procedure om de habitattypekaarten om te zetten naar deze database is ook bij de vorige rapportage doorlopen; hiervoor is een eerder opgesteld script gebruikt.

\section{Vegetatieopnamen}

Vegetatieopnamen zijn afkomstig uit de Landelijke Vegetatie Databank (LVD; versie 29-05-2018), die wordt beheerd door WENR (zie Schaminée et al. 2006). Voor de rapportage zijn opnamen gebruikt uit de periode 2007-2018. De selectie van vegetatieopnamen die tot een habitattype behoren, gebeurt in twee stappen: (1) toedeling van opnamen aan relevante plantengemeenschappen, via het algoritme ASSOCIA (Van Tongeren et al. 2006), (2) en toedeling van opnamen aan habitattypen, op basis van aanvullende criteria (zie Bijlage 3). Bij dit laatste worden verschillende GIS-bestanden gebruikt. De aanvullende criteria zijn een vertaling van de definitie (profielen) naar een toepassing op dit schaalniveau van $10 \times 10 \mathrm{~km}^{2}$ met beschikbare GIS-kaarten.

\section{Waarnemingen}

Bij WENR is een Excel-bestand van aanvullende 'waarnemingen' in beheer, dat tijdens de vorige rapportageperiode speciaal is opgezet voor het opvullen van gaten in verspreiding van habitattypen op basis van andere bronnen en veldwaarnemingen, zonder dat harde gegevens voorhanden zijn. Het bestand bestaat uit het habitattype, een jaartal, een km-hok nummer en een toelichting op de 'waarneming'. Het bevat voor de rapportageperiode met name waarnemingen van de habitattypen 3130 en 5130.

\section{Procedure}

In het kennissysteem SynBioSys Nederland (Schaminée et al. 2013) wordt - op basis van de drie databronnen - geautomatiseerd een verspreidingskaart gegenereerd van 10x10 km-hokken in RDcoördinaten of in het ETRS coördinatenstelsel, voor een zelf instelbare periode. Voor het maken van de

\footnotetext{
${ }^{1}$ De habitatkaarten in hun laatste versie zijn alleen per Natura 2000-gebied beschikbaar. Zestig (39\%) van deze kaarten waren in maart 2018 nog niet formeel goedgekeurd door de Interbestuurlijke Werkgroep Habitatkaarten. De geaggregeerde versie die voor Aerius wordt gebruikt is dan ook niet altijd up-to-date en bevat bovendien een aanzienlijk aandeel niet formeel goedgekeurde habitattypenkaarten.
} 
verspreidingskaarten worden perioden van 12 jaar gehanteerd, in dit geval 2005-2016. ${ }^{2}$ Deze kaart kan met of zonder 'opvul' van tussenliggende hokken worden uitgevoerd. ${ }^{3} \mathrm{Er}$ vindt een controle op de kaarten plaats door de invullers (experts), waarbij zo nodig per habitattype de onderliggende gegevens worden bekeken en gecorrigeerd. Dit is met name van belang bij $10 \times 10 \mathrm{~km}$-hokken die door weinig data worden onderbouwd, of nieuw zijn of verdwenen zijn ten opzichte van de vorige rapportage. Eventueel kunnen nieuwe hokken worden uitgesloten, of extra, ontbrekende hokken worden toegevoegd via het bestand 'waarnemingen', waarbij dan telkens een bron per waarneming wordt vermeld. Een voorbeeld van een in SynBioSys gemaakt verspreidingskaart is weergegeven in Figuur 2.1.

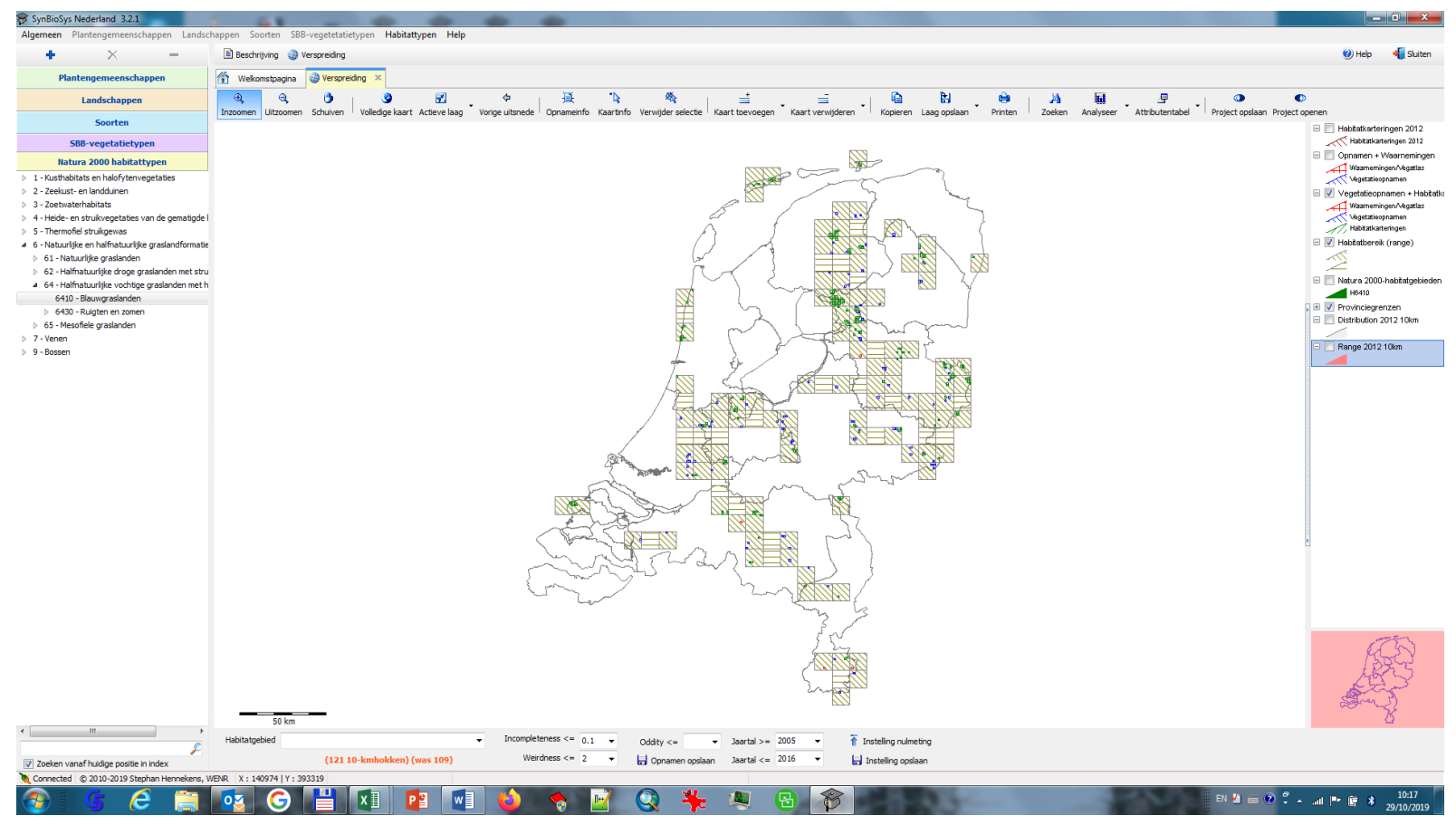

Figuur 2.1 Verspreidingskaart van het habitattype 6410 op basis van data uit de periode 2005-2016. Deze kaart wordt automatische gegenereerd in het kennissysteem SynBioSys uit een drietal bronbestanden (zie tekst). De kaart is in oktober 2019 gegenereerd en bevat inmiddels één hok aanvullende gegevens ten opzichte van de kaart die voor de rapportage is gegenereerd; de oorzaak van het verschil is dat er inmiddels nieuwe opnamegegevens uit de periode 2005-2016 aan de Landelijke Vegetatie Databank zijn toegevoegd.

\section{Trendanalyse}

De korte termijntrend wordt afgeleid uit vergelijking met de verspreidingskaart van de vorige rapportage, waarbij expert-oordeel nodig is om te bepalen of een korte termijntrend echt is opgetreden of een gevolg is van verschillen in beschikbare data. In principe wordt een marge van $10 \%$ verandering aangehouden, alvorens te besluiten tot een positieve of negatieve trend. Deze marge wordt gehanteerd vanwege onzekerheden (bijv. waarnemingsintensiteit) in de beschikbare basisgegevens.

Tijdens de analyse van trends kwam naar voren dat in de vorige rapportage van 2013 niet alle waarnemingen (uit de derde bron) goed doorgevoerd zijn in de verspreidingskaarten. Om zo goed mogelijk de trend te kunnen bepalen, zijn deze correcties doorgevoerd, wat bij veel habitattypen heeft geleid tot een andere oppervlakte van het verspreidingsgebied in 2013. De correcties en de gerapporteerde trends zijn vermeld in Bijlage 4.

\footnotetext{
${ }^{2}$ Het format schrijft een kortere periode voor, maar omdat de drie bronbestanden niet elke 6 jaar worden geüpdatet wordt er met data uit een periode van 12 jaar gewerkt bij het genereren van verspreidingskaarten van habitattypen.

3 De opvulling is een methode die vanuit de EU wordt voorgeschreven.
} 


\subsection{Gunstige referentiewaarden}

Gunstige referentiewaarden voor verspreidingsgebied (FRR: Favourable Reference Range) zijn in principe niet opnieuw beoordeeld volgens aangepaste richtlijnen (DG Environment 2017; Bijlsma et al. 2019a) maar ontleend aan Bijlsma et al. (2014) die op vergelijkbare wijze zijn bepaald. Wel is de FRR voor H1110 gecorrigeerd ten opzichte van H1130 (zie §2.2).

\subsection{Resultaten}

De resultaten van de verspreidingskaarten zijn opgenomen in Bijlage 4. Na correctie en uitgaande van $10 \%$ onzekerheidsmarge is het verspreidingsgebied ten opzichte van de vorige rapportage bij slechts één type veranderd, te weten een afname van 900 naar $700 \mathrm{~km}^{2}$ voor habitattype 3110, Zeer zwak gebufferde vennen. Een belangrijke oorzaak is dat dit habitattype slechts in weinig gridcellen voorkomt, waardoor het verdwijnen uit één of twee cellen al snel tot een overschrijding van de $10 \%$ marge leidt. Voor habitattype 9120, Beuken-eikenbossen met hulst, is het verspreidingsgebied als matig ongunstig beoordeeld ten opzichte van gunstig in 2013 vanwege een herbeoordeling (correctie) van opnamen in de Landelijke Vegetatiedatabank (zie §2.6). Mogelijk moet de referentiewaarde van het verspreidingsgebied ook gecorrigeerd worden, wat tot een andere SvI score zou kunnen leiden., maar dat is niet uitgezocht.

Bij alle overige typen is het verspreidingsgebied stabiel, binnen de gehanteerde marges.

Het uitbreiden van het Natura 2000-netwerk met het gebied 'Maas bij Eijsden' door de uitwisseling van een stukje land aan de grens met België heeft geen grote consequenties voor het verspreidingsgebied van de daar aangemelde habitattypen H3260, H6430, H91E0.

\subsection{Discussie}

\section{Habitatkaarten}

De in 2012 gebruikte habitatkaart verschilt van de in 2018 gebruikte habitatkaart (beide een versie die in het stikstofdepositie-model Aerius wordt gebruikt). Dit kan een oorzaak zijn van verschillen tussen het verspreidingsgebied in 2012 en 2018, naast andere ligging van opnamen en waarnemingen, en daadwerkelijke veranderingen. De oorzaken van verschillen tussen beide kaarten zijn niet geanalyseerd. Ook is een deel van de habitatkaarten die in het bestand zitten nog niet gevalideerd en goedgekeurd.

\section{Landelijke Vegetatie Databank}

Na de rapportage van 2013 zijn in de Landelijke Vegetatie Databank niet alleen opnamen toegevoegd van de afgelopen zes jaar, maar ook extra opnamen uit de vorige rapportageperiode bijgekomen, niet alleen door (i) het ná 2012 toevoegen aan de LVD van opnamen uit de periode 2001-2012, maar ook doordat (ii) circa 8000 opnamen die in 2012 al in de LVD waren opgenomen geen km-hok-aanduiding hadden, terwijl ze wel $\mathrm{XY}$-coördinaten hadden; zonder km-hok aanduiding werden ze toen niet meegenomen in de verspreidingsdata (inmiddels wordt een $\mathrm{XY}$-aanduiding automatisch naar een $\mathrm{km}$ hok aanduiding omgezet); als gevolg van (i) en (ii) kan bij het automatisch genereren van een oude verspreidingskaart (uit de periode 2001-2012) de range (als getal) hoger uitvallen dan is gerapporteerd in 2013. Deze verschillen zijn nader bekeken indien de range een toe- of afname laat zien. Een voorbeeld van een dergelijk verschil laat Figuur 2.1 zien, waar - ten opzichte van de gerapporteerde kaarten - een extra hok voor het habitattype 6410 wordt gegenereerd.

\section{Van opnames naar verspreidingskaart}

De vertaling van opnames in de LVD naar habitattypen gebeurt in twee stappen. In de eerste stap worden opnames via het programma ASSOCIA aan plantengemeenschappen gerefereerd. Het is bekend dat ASSOCIA niet voor alle plantengemeenschappen goed werkt, maar het is niet precies bekend in welke gevallen het algoritme relatief goed of relatief slecht werkt. Op dit moment is er echter een alternatief algoritme in ontwikkeling, genaamd EXPERT, dat voor een betere en $100 \%$ 
consistente toedeling van opnames aan plantengemeenschappen moet zorgen. Dit programma zal bij de volgende rapportage in gebruik worden genomen, waarbij dan wel moet worden bekeken wat het effect op de verspreidingskaarten is, van een nieuw toedelingsalgoritme.

Voor de tweede stap (van plantengemeenschap naar habitattype) is een set criteria gebruikt die ook bij de vorige rapportage is gebruikt. Deze criteria benaderen de definities uit de profielen, maar komen niet precies overeen, omdat sommige definities in de profielen niet af te leiden zijn uit GISbestanden en opnameninformatie (bijv. de grootte van het voorkomen van een habitattype op een plek). Het zou goed zijn om voor een volgende rapportage de criteria en gebruikte GIS-bestanden in deze tweede stap te evalueren en zo mogelijk beter af te stemmen op criteria en GIS-bestanden die voor de habitatkaarten gebruikt worden.

\section{Trend in verspreiding}

Voor de trend in het verspreidingsgebied van habitattypen is nu -arbitrair - een marge van $10 \%$ gehanteerd, om rekening te houden met de onzekerheden in de data. De gegevens voor verspreiding worden ad hoc verzameld, waardoor het moeilijk te bepalen is in hoeverre de gegevens volledig zijn of in hoeverre de waarnemingsinspanning tussen rapportageperioden verschilt. Voor de toekomst wordt bekeken of het mogelijk is een statistisch model te ontwikkelen om de trend in verspreiding te bepalen, net zoals dat bij soorten wordt gebruikt. In zo'n model kan gecorrigeerd worden voor waarnemingsintensiteit. 



\section{Rapportage Oppervlakte}

\subsection{Format}

In het voorgeschreven format zijn de volgende gegevens de belangrijkste die moeten worden gerapporteerd:

- Oppervlakte $\left(\mathrm{km}^{2}\right)$ van het habitattype in Nederland

- Trend in landelijke oppervlakte

- Oppervlakte binnen het Natura 2000-netwerk

- Gunstige referentiewaarden

Het betreft paragraaf 5 uit het reporting format (bijlage 2).

\subsection{Data en werkwijze mariene habitattypen}

Voor habitattype 1110 is de gerapporteerde oppervlakte $\left(11.900 \mathrm{~km}^{2}\right)$ gebaseerd op het "profiel habitattype 1110" uit 2014. Hierin worden oppervlaktes per subtype vermeld van respectievelijk 130.000 ha (subtype A), 590.000 ha (subtype B) en 470.000 ha (subtype C). Heel nauwkeurige gegevens zijn niet bekend, en Bos et al. (2008) komen in een eerder overzicht uit op een oppervlakte van $12.854 \mathrm{~km}^{2}$ voor heel Nederland, terwijl Janssen et al. (2014) een oppervlakte van $12.156 \mathrm{~km}^{2}$ noemen.

Voor habitattypen 1130, 1140 en 1160 is de landelijke oppervlakte overgenomen van het SDF-rapport (Janssen et al. 2014).

Voor 1170 is de oppervlakte uit het SDF-rapport $\left(720 \mathrm{~km}^{2}\right)$ gecorrigeerd op basis van recent onderzoek op de Klaverbank en de Borkumse Stenen (Bos et al. 2014, Eurofins/Aquasense et al. 2018, Van den Oever et al. 2018). Bos et al. (2014) rapporteren een oppervlakte van 979 ha van $\mathrm{H} 1170$ in het goed onderzochte zuidelijke deel van de Borkumse Stenen. Gebaseerd op side-scan waarnemingen sinds 2009, en extrapolatie van mogelijke aanwezigheid van hard substraat op basis van Duitse data, komen ze tot een mogelijke oppervlakte van 1980 ha van habitattype 1170 in het gehele gebied van de Borkumse Stenen.

Van den Oever et al. (2018) noemt voor de Klaverbank de aanwezigheid van 200 ha van habitattype 1170 met zekerheid, een aanvullend oppervlakte van 25.700 ha dat met hoge waarschijnlijkheid als 1170 kan worden geclassificeerd en een oppervlakte van 36.300 ha dat mogelijk habitattype 1170 betreft. De som van zeker, waarschijnlijk en mogelijk oppervlakte van habitattype 1170 binnen de Klaverbank bedraagt op basis van deze gegevens 62200 ha, wat in de buurt komt van de inschatting uit het SDF-rapport van 61882 ha (Janssen et al. 2014, op basis van Bos et al. 2008).

Er liggen ook nog gedeelten ten noorden en ten zuiden van het habitatrichtlijngebied Klaverbank die mogelijk kwalificeren voor 1170 (Eurofins/Aquasense et al. 2018), samen zo'n 1600 ha. Deze worden meegenomen in de landelijk gerapporteerde oppervlakte, om ook te compenseren voor eventuele gebieden elders op de Noordzee die aan de criteria van 1170 voldoen. De totale gerapporteerde oppervlakte (van Borkumse Stenen en Klaverbank) komt daarmee uit op 658 km².

\subsection{Data en werkwijze terrestrische habitattypen}

In de voorgaande rapportage uit 2013 is de oppervlakte van habitattypen gebaseerd op een combinatie van habitattypenkaarten (voor de oppervlakte binnen Natura 2000-gebieden) en een expert-inschatting van de verspreiding binnen en buiten het Natura2000-netwerk (mede op basis van verspreidingskaarten). Beide bronnen samen hebben geleid tot een schatting van de landelijke oppervlakte per habitattype, die vermeld is in het rapport over de SDFs (Janssen et al. 2014). 
Voor de huidige rapportage in 2019 zijn - op een enkele uitzondering na (zie verderop) - geen nieuwe gegevens geanalyseerd over de oppervlakte ten opzichte van de data die zes jaar geleden is gerapporteerd. De reden hiervoor is dat slechts een klein deel van de habitattypenkaarten in de tussentijd geactualiseerd is, en een groot deel nog steeds niet definitief is. Nieuwe waarden berekend op basis van recente habitatkaarten zouden daarmee nog steeds niet $100 \%$ goed zijn (voor wat de habitatkaarten betreft). De insteek is dat het pas zin heeft om tijd en geld te steken in betere gegevens over de oppervlakte, op het moment dat vlakdekkende karteringen eenvoudig en volledig (voor N2000) beschikbaar zijn, via de NDVH (Nationale Database Vegetatie en Habitats). Ter illustratie van deze onzekerheden worden in bijlage 5 de verschillen in de oppervlakte van habitattypen berekend tussen de habitatkaarten van de landelijke Aerius-kaart uit 2017 en de gerapporteerde oppervlakte in 2013.

Voor de meeste habitattypen zijn dan ook geen trendgegevens voorhanden. Op basis van expertkennis zijn soms toch negatieve of positieve trends in landelijke oppervlakte gerapporteerd, waarbij dan telkens een onderbouwing is gegeven in het veld 5.15 van het rapportage format.

Uitzonderingen (habitattypen waarvoor wel een aangepaste oppervlakte is gerapporteerd) zijn:

- Kweldertypen 1310 en 1330, waarvoor 6-jaarlijks nieuwe gegevens worden ingewonnen en geanalyseerd door Rijkswaterstaat, mede ten behoeve van rapportages voor de KRW. In paragraaf 4.4.1 worden de bronnen genoemd die voor deze habitattypen zijn gebruikt.

- Habitattype 7220 (kalktufbronnen) waarvoor een volledige inventarisatie is uitgevoerd door Ramaekers (2014).

\subsection{Gunstige referentiewaarden}

Gunstige referentiewaarden voor oppervlakte (FRA: Favourable Reference Area) zijn niet opnieuw beoordeeld volgens aangepaste richtlijnen (DG Environment 2017; Bijlsma et al. 2019a) maar ontleend aan Bijlsma et al. (2014) die op goed-vergelijkbare wijze zijn bepaald. Een uitzondering vormt habitattype 9120 (Beuken-eikenbossen met hulst) waarvan de FRA moet worden aangepast, op basis van Bijlsma et al. (2019b). Deze aanpassing (vergroting van FRA) is het gevolg van meer nadruk op het belang van ruimtelijke samenhang van oppervlakte. Vooruitlopend op deze aanpassing is de beoordeling voor dit habitattype negatiever dan bij de vorige rapportage.

\subsection{Resultaten}

Voor de mariene habitattypen 1110 en 1170 is de oppervlakte aangepast ten opzichte van de vorige

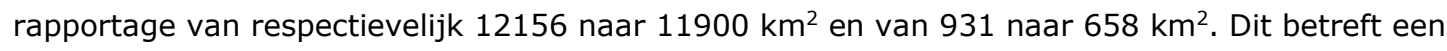
aanpassing op basis van betere gegevens, geen werkelijke uitbreiding.

De kweldertypen 1310 en 1330 zijn beide enigszins uitgebreid in oppervlakte, respectievelijk van 23 naar $25 \mathrm{~km}^{2}$ en van 106 naar $108 \mathrm{~km}^{2}$. Omdat deze data nauwkeurig wordt ingewonnen, zijn beide veranderingen als betrouwbaar genoeg beoordeeld om een positieve trend in landelijke oppervlakte te rapporteren.

Voor habitattype 7220 is de oppervlakte in de rapportage aangepast ten opzichte van de vorige rapportage van 0.003 naar $0.007 \mathrm{~km}^{2}$. Ook dit betreft een aanpassing op basis van betere gegevens, geen werkelijke uitbreiding.

Voor habitattype 9120 is dezelfde oppervlakte gerapporteerd als bij de vorige rapportage, maar de beoordeling van de staat van instandhouding negatiever. Zoals hierboven al aangegeven, is de reden een anders ingeschatte FRA-waarde, op basis van het voorbeeld van deze Beuken-eikenbossen met hulst in Bijlsma et al. (2019b).

Voor de volgende habitattypen zijn positieve of negatieve trends gerapporteerd (waarbij geen andere waarde voor de oppervlakte is gegevens, aangezien er geen betrouwbare data zijn): 


\section{Grote baaien}

positieve trend, op basis van uitbreiding van de baai van de Oosterschelde met het gebied Rammegors;

\section{Embryonale duinen}

positieve trend, op basis van uitbreiding van het habitattype langs de Hollandse kust en bij de Kwade Hoek (op basis van expert kennis);

\section{Grijze duinen}

negatieve trend, op basis van uitbreiding struweel in Meijendel (Mücher et al. 2017) en in NEM-PQ's (zie §4.6.2 en http://www.clo.nl/indicatoren/nl1535-vegetatie-duinen);

\section{Duindoornstruwelen}

positieve trend, op basis van uitbreiding struweel in Meijendel (Mücher et al. 2017) en in NEM-PQ's (zie §4.6.2 en http://www.clo.nl/indicatoren/nl1535-vegetatie-duinen);

\section{Beken en rivieren met waterplanten}

negatieve trend, op basis van gegevens over de Swalm (waar het habitattype vrijwel verdwenen is, expert kennis) en de beken op de flank van de Veluwe (waar bij een recente, nog niet gepubliceerde inventarisatie een sterke achteruitgang is geconstateerd);

\section{Zinkweiden}

onbekende trend, op basis van een combinatie van uitbreiding door middel van plagexperimenten en herintroducties (Van de Riet \& Bobbink 2018) en achteruitgang van resterende zinkgrasland (expert kennis);

\section{Actieve hoogvenen}

positieve trend, op basis van uitbreiding als gevolg van diverse herstelprojecten waarbij uitbreiding van actieve veenvorming optreedt;

\section{E0 Vochtige alluviale bossen}

negatieve trend, op basis van voortgaande verwijdering van bos in het rivierengebied uit het oogpunt van waterveiligheid.

Voor alle overige habitattypen is een stabiele trend gerapporteerd, aangezien er geen betrouwbare data zijn over positieve of negatieve trends in landelijke oppervlakte.

\subsection{Discussie}

Het is van groot belang dat voor een volgende rapportage de habitatkaarten in de NDVH voor het hele Natura 2000-netwerk zijn gevalideerd, én dat eenvoudig landelijke oppervlaktegegevens uit deze databank kunnen worden bepaald.

Daarnaast zou het voor de landelijke rapportage bijzonder nuttig zijn om ook de vegetatiekaarten van buiten het Natura2000-netwerk die in de NDVH zijn opgeslagen, via een eenvoudige vertaalslag om te zetten naar habitatkaarten, zodat ook de oppervlakte van habitattypen buiten het Natura 2000netwerk preciezer in beeld komt. 



\section{$4 \quad$ Rapportage Structuur en Functie (S\&F)}

\subsection{Format}

Het format vraagt het volgende te rapporteren (zie Bijlage 2):

1. oppervlakte in goede/niet-goede/onbekende conditie(format 6.1-6.2);

2. trend in goede oppervlakte (format 6.3-6.5);

3. lijst typische soorten (format 6.6).

4. eindoordeel voor parameter Structuur \& Functie (inclusief typische soorten) (format 10.3)

\subsection{Uitgangspunten werkwijze}

Evenals voor eerdere rapportageperioden worden S\&F in strikte zin (d.w.z. exclusief Typische soorten) en Typische soorten afzonderlijk beoordeeld. De te rapporteren oppervlakten (in goede/niet goede/onbekende conditie) en trend in goede oppervlakte zijn nieuw ten opzichte van eerdere rapportages en vereisten een nieuwe werkwijze voor de beoordeling van S\&F in strikte zin. Voor het eindoordeel worden beide beoordelingen gecombineerd.

\subsubsection{S\&F in strikte zin}

Als uitgangspunten bij het ontwikkelen van een methode voor de beoordeling van S\&F in strikte zin zijn gehanteerd:

- $\quad$ Er wordt een navolgbare (reproduceerbare) methode ontwikkeld, waarin de doorlopen stappen worden vastgelegd en expert-kennis zo veel mogelijk wordt gereduceerd.

- De beoordeling wordt zo veel mogelijk uitgevoerd op basis van bestaande data waarvan verwacht wordt dat die ook in de toekomst langdurig zal worden ingewonnen; er wordt dus aangesloten bij lopende monitoring; er wordt niet uitgegaan van nieuwe monitoring.

- De methode van beoordeling kan tussen habitattypen verschillen, maar is voor groepen van habitattypen gelijk. Hierbij zijn de volgende vier hoofdgroepen onderscheiden:

- Mariene habitattypen (1110 t/m 1170): voor deze typen wordt aangesloten bij de monitoring van de BISI indicator die is ontwikkeld voor de Kaderrichtlijn Marien (KRM). Zie §4.3.

- Aquatische habitattypen (3110 t/m 3260) en kwelders (1310 t/m 1330): voor deze typen wordt primair aangesloten bij de monitoring die is ontwikkeld voor de Kaderrichtlijn Water (KRW). Zie §4.4.

- Soortenrijke terrestrische habitattypen: voor deze hoofdgroep wordt gebruik gemaakt van drie perioden van verspreidingsgegevens van karakteristieke soorten in de Nationale Databank Flora en Fauna (NDFF). Zie §4.5.

- Door weinig soorten gedomineerde terrestrische habitattypen: bij deze 'overige' habitattypen is de vraag welke indicator geschikt is om een goede kwaliteit te monitoren; vooralsnog is voor deze typen geen nieuwe methode ontwikkeld, en wordt teruggevallen op de eerder ontwikkelde methode van het opschalen van beoordelingen op gebiedsniveau in Bijlsma \& Janssen (2014). Zie §4.5.

Naast deze belangrijkste gegevensbronnen (KRM, KRW en NDFF) worden zo mogelijk ook gegevens uit andere langlopende monitoring gebruikt, zoals

- $\quad$ Bosstatistieken voor bossen (NBI, MFV); zie §4.6.

- $\quad$ NEM-PQ reeksen; zie $\$ 4.7$.

De indicatoren die gebaseerd zijn op de meetnetten NDFF, NBI en KRW leiden tot een conclusie over het percentage (NDFF, NBI) of oppervlakte (KRW) habitat in goede, matige, slechte of onbekende 
staat. De percentages worden vervolgens via de landelijke oppervlakte (area) omgerekend tot de in te vullen oppervlakte in goede of niet-goede staat.

\subsubsection{Typische soorten}

De wijze van beoordeling van typische soorten komt vrijwel overeen met die van de vorige rapportageperiode (Bijlsma \& Janssen 2014). Zie §4.4.2 voor details.

\subsubsection{Eindoordeel Structuur \& Functie inclusief Typische soorten}

De bepaling van de aandelen oppervlakte habitattype in goede en niet-goede staat geeft aanleiding tot een voorlopige beoordeling van de staat van instandhouding (SvI). Afhankelijk van de hoofdgroep (zie hierboven) zijn hierbij verschillende data gebruikt en zijn er aanvullende beoordelingen beschikbaar, bijvoorbeeld voor bossen of habitattypen met voldoende NEM-PQ's. Deze aanvullende beoordelingen kunnen aanleiding zijn de SvI aan te passen. Tot slot worden deze SvI en de beoordeling van typische soorten gewogen tot een definitief oordeel (figuur 4.1 en zie bijlage 6 voor een uitgebreid schema).

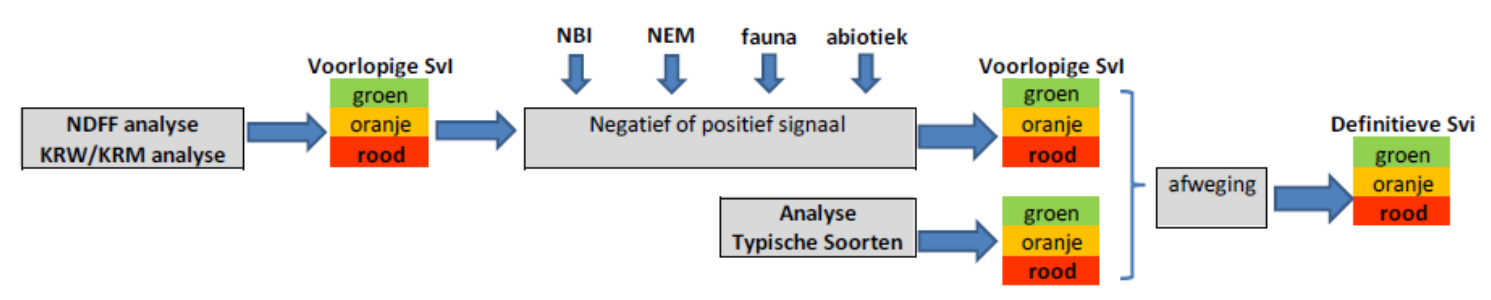

Figuur 4.1 Werkwijze beoordeling Structuur \& Functie inclusief Typische soorten. Zie tekst voor toelichting.

\subsection{Werkwijze en data mariene typen}

De structuur \& functie wordt op basis van twee verschillende gegevenssets beoordeeld: voor de Noordzee-typen (1110 en 1170, inclusief 1110A) wordt de data en methodiek gevolgd van de Kader Richtlijn Marien (KRM), te weten benthos monitoring volgens de Benthische Indicator Soorten Index (BISI); Wijnhoven \& Bos 2017). Voor de typen in de overgangswateren $(1130,1140,1160)$ worden in principe KRW-monitoringsgegevens gebruikt. In de praktijk is de beoordeling van deze laatste drie typen op basis van expert-kennis gedaan. Voor 1110 (subtypen B en C) en 1130 konden ook de typische soorten worden beoordeeld (zie §4.5.2 en bijlage 8).

\section{Permanent overstroomde zandbanken}

De beoordeling van de kwaliteit van habitattype 1110 is gebaseerd op BISI-gegevens (Wijnhoven \& Bos 2017) waarvoor de resultaten van de T0 (quality status in 2015) zijn vergeleken met historische ontwikkelingen in Wijnhoven (2018). Er zijn kwaliteitsbeoordelingen voor de afzonderlijke habitatrichtlijngebieden en voor het overige deel van het NCP. Gegevens van T1 (in 2018 ingewonnen) waren voor deze rapportage nog niet beschikbaar. De BISI is alleen voor de Noordzeegebieden ontwikkeld, dus (nog) niet voor subtype A van $\mathrm{H} 1110$.

Op dit moment is er nog geen S\&F-maatlat voor de beoordeling van de BISI-waarden, noch voor MSFD-gebieden, noch voor Natura 2000-habitattypen. Voor de 2019-rapportage is een BISI-score in de periode 2012-2018 hoger dan 0,8 als goede S\&F beschouwd, een BISI-score tussen 0,5 en 0,8 als matige S\&F, en een BISI-score onder 0,5 als een slechte S\&F. De oppervlakte H1110A (1300 km², circa $11 \%$ van het totaal) is als onbekend gescoord. Subtype $1110 \mathrm{~B}$ (5900 km²,50\% van het totaal) heeft een score onder de 0.5 , waarbij van vier verschillende methoden alleen de dredge-methode recent hogere waarden geeft (Van Wijnhoven 2018, Figuur 16). Subtype $1110 \mathrm{C}\left(4700 \mathrm{~km}^{2}, 39 \%\right.$ van het totaal) heeft een negatieve trend, waarbij de score tussen 1995 en 2015 gezakt is, maar nog wel net boven de 0.5 ligt (Wijnhoven 2018, Figuur 16). Wel is er een recente positieve trend (zie verderop). In totaal is er dus meer dan $25 \%$ van het type met een slechte structuur \& functie, wat een beoordeling U2 heeft opgeleverd. 
Trend analyses op basis van historische data van MWTL/BIOMON (boxcores) en de WOt Schelpdiersurveys (dredges) geven een indicatie van de ontwikkeling van deze kwaliteits-indicator, maar wel met flinke mate van onzekerheid. Trend analyse in BISI is uitgevoerd voor twee periodes van 12 jaar, te weten 2004-2015 en 2007-2017. Deze periodes zijn vergeleken met respectievelijk de periodes 1998-2009 en 2001-2012. Mogelijke significante verschillen zijn geanalyseerd op basis van data uit boxcores, dredges, en een combinatie van beide monitoringstechnieken. Ze zijn weergegeven in Tabel 4.1. Omdat in de rapportage de trend van de oppervlakte in goede staat wordt gevraagd (alleen subtype $1110 \mathrm{C}$ komt hiervoor in aanmerking), is een positieve trend gescoord bij 6.4. Hierbij moet dus wel worden opgemerkt dat er een jarenlange negatieve trend is geweest (zie Tabel 4.1), en dat er pas recent enig herstel optreedt. Voor H1110B is de kwaliteit jarenlang slecht geweest, maar zijn er ook eerste signalen van herstel.

Tabel 4.1 Testresultaten van vergelijking van trends op basis van Linear Models (LM, waarbij mogelijke verschillen in hellingshoek zijn getest) in BISI-scores voor data van verschillende monitoringstechnieken voor habitattypen $H 1110 B$ en $H 1110 C$. Voor H1110B zijn twee verschillende periodes onderling vergeleken. $n s^{-}=$niet significante negatieve trend; $n s+=$ niet-significante positieve trend; + = significante toename BISI-waarde; - = significant afname BISI-waarde. De significante trends zijn in rood weergegeven.

\begin{tabular}{|c|c|c|}
\hline \multirow[t]{8}{*}{ H1110B } & 2001-2012 vs 2007-2015 & LM testing \\
\hline & Boxcore & ns- vs ns+ \\
\hline & Dredge & $\mathrm{ns}+\mathrm{vs} \mathrm{ns}+$ \\
\hline & Boxcore+Dredge & ns+ vs ns+ \\
\hline & 1998-2009 vs 2004-2015 & LM testing \\
\hline & Boxcore & ns- vs ns- \\
\hline & Dredge & $n s+v s+(p<0,05)$ \\
\hline & Boxcore+Dredge & ns+ vs ns+ \\
\hline \multirow[t]{4}{*}{ H1110C } & 2001-2012 vs 2007-2015 & LM testing \\
\hline & Boxcore & $-(p<0,05)$ vs ns- \\
\hline & 1998-2009 vs 2004-2015 & LM testing \\
\hline & Boxcore & $-(p<0,01)$ vs ns- \\
\hline
\end{tabular}

\section{Estuaria}

Voor habitattype 1130 is ingeschat dat het habitattype als geheel een ongunstige S\&F heeft. Dit wordt onderbouwd door diverse onderzoeken die - op verschillende wijze - de status van de estuaria van de Westerschelde en de Eems-Dollard beoordelen. Voor de Westerschelde zijn onderzoeken van de laatste decennia samengevat in een gezamenlijke (Vlaams-Nederlandse) Systeemanalyse natuur Schelde-estuarium, uitgebracht door de Vlaams-Nederlandse Scheldecommissie (2019).

Op basis van hetzelfde rapport wordt een negatieve trend gerapporteerd. De onderbouwing daarvoor is dat de oppervlaktes van de ecotopen matig diep water, ondiep water en laag slik verder zijn afgenomen. Dit gaat ten koste van foerageergebied voor steltlopers, een functie die al onder druk staat.

\section{Slik- en zandplaten}

Voor het habitattype 1140, dat voornamelijk in de Waddenzee wordt aangetroffen, is op dit moment geen methode voor de beoordeling van de oppervlakte met goede en met niet-goede structuur \& functie voorhanden. Net als bij habitattype 1130 en 1160 zijn er allerlei aspecten die gemeten en afgewogen moeten worden voor een beoordeling (zie o.a. Sas 2016 en het Quality Status Report Wadden Sea (http://qsr.waddensea-worldheritage.org/). De totale oppervlakte is gerapporteerd met 'onbekende' status van structuur \& functie. Ook de trend van habitattype 1140 is onbekend gescoord.

\section{Grote baaien}

Voor de baai van de Oosterschelde is de gehele structuur \& functie als ongunstig beoordeeld, mede op basis van het bij 1130 genoemde rapport Systeemanalyse natuur Schelde-estuarium (Vlaams- 
Nederlandse Scheldecommissie 2019). De trend wordt als negatief ingeschat als gevolg van voortgaande erosie van slikplaten en kwelders. Net als bij de estuaria gaat dat ten koste van foerageergebied voor steltlopers.

\section{Riffen}

Vergelijkbaar met de methodiek bij habitattype 1110 is de kwaliteit van de riffen beoordeeld op basis van de benthos indicator BISI (Wijnhoven \& Bos 2017). Een (gedeeltelijke) beoordeling was mogelijk voor de jaren 2002 en 2015, met aanvullende, beperkte informatie (uit video waarnemingen) in 2011 De resultaten laten een gelijkblijvende of licht verbeterende BISI zien (Wijnhoven 2018). In 2015 ligt de BISI waarde rond 0,5 of net eronder (op basis van alleen video data). Deze waarden zijn op vergelijkbare wijze als bij $\mathrm{H} 1110$ beoordeeld, wat leidt tot de conclusie matig tot slechte structuur \& functie. De volledige oppervlakte van de Klaverbank (incl. het gebied ten zuiden daarvan, samen 638 $\mathrm{km} 2$ ) is daarom bij 6.1 ingevuld bij zowel Maximum area in good condition als bij Maximum area in non-good condition. De oppervlakte van de Borkumse Stenen (20 km2) is als 'onbekend' gescoord bij 6.1. De resultaten worden als voorlopig beschouwd, aangezien de metingen in 2015 en daarvoor niet specifiek op habitattype 1170 gericht waren. Zo zijn er ook zandige delen van het habitatrichtlijngebied Klaverbank beoordeeld. De data uit 2015 geeft daarom meer een beeld van de Klaverbank als geheel, dan van het habitattype 1170 . Analyse van trends is nog niet mogelijk als gevolg van de beperkte data beschikbaarheid in tijd en ruimte (beperkt tot enkele gebieden) in het verleden (Van Moorsel 2003; Wijnhoven 2018). Werkwijze en data kwelders en aquatische typen

\subsubsection{Kwelders $(1310,1330)$}

Voor de kweldertypen 1310 en 1330 wordt de structuur \& functie beoordeeld aan de hand van een maatlat die voor de KRW is ontwikkeld en waarmee wordt beoordeeld in hoeverre er in een gebied een evenwichtige opbouw is van de verschillende zones op de kwelder, te weten: pionier (P), laag (L), midden (M), climax hoog (incl. strandkweek) $(H)$, en climax brak (incl. riet) (B). Deze maatlat is uitgewerkt door Dijkema et al. (2005) en enigszins aangepast door Wielakker et al. (2011; zie ook Jentink 2018). Het criterium is dat een zone niet meer dan 35\% (of 40\%) van de totale oppervlakte beslaat en niet minder dan $5 \%$ van het totaal. Bovendien mag het aandeel climax-begroeiing met strandkweek niet meer dan 50\% van de hoge zone beslaan, en het aandeel climax-begroeiing met riet niet meer dan $50 \%$ van de brakke zone.

De beoordeling vindt plaats voor deelgebieden. Per deelgebied wordt beoordeeld hoeveel zones en climax-begroeiingen aan de beide criteria voldoen, waarbij - afhankelijk van het aantal zones en climax-begroeiingen dat voorkomt (de brakke zone en climax ontbreekt in veel gebieden) - een totaal van 5 tot 7 punten gehaald kan worden. Afhankelijk van hoeveel punten gehaald worden, geldt voor de KRW dan een score P-REF, GET, matig, ontoereikend of slecht. De eerste twee scores worden voor de Habitatrichtlijn omgezet naar Favourable, de matige score naar Unfavourable-insufficient (oranje), de twee laatste naar Unfavourable-Bad (Rood). De scores en zones per gebied zijn aangegeven in onderstaande Tabel 4.2.

Uiteindelijk wordt voor beide habitattypen apart de S\&F-score per gebied gewogen naar de oppervlakte (van resp. 1310 en 1330) en zo opgeschaald naar een landelijke score. De binnendijks gelegen habitattypen 1310 en 1330 worden in de analyse niet meegenomen. De benedengrens voor habitattype 1310 ligt bij 5\% bedekking. Oppervlaktes met een lagere bedekking worden niet meegenomen, omdat de oppervlakte daarvan jaarlijks te sterk varieert. 
Tabel 4.2 Maatlat beoordeling Structuur \& Functie voor de kwelderhabitattypen 1310 en 1330. Zie tekst voor toelichting.

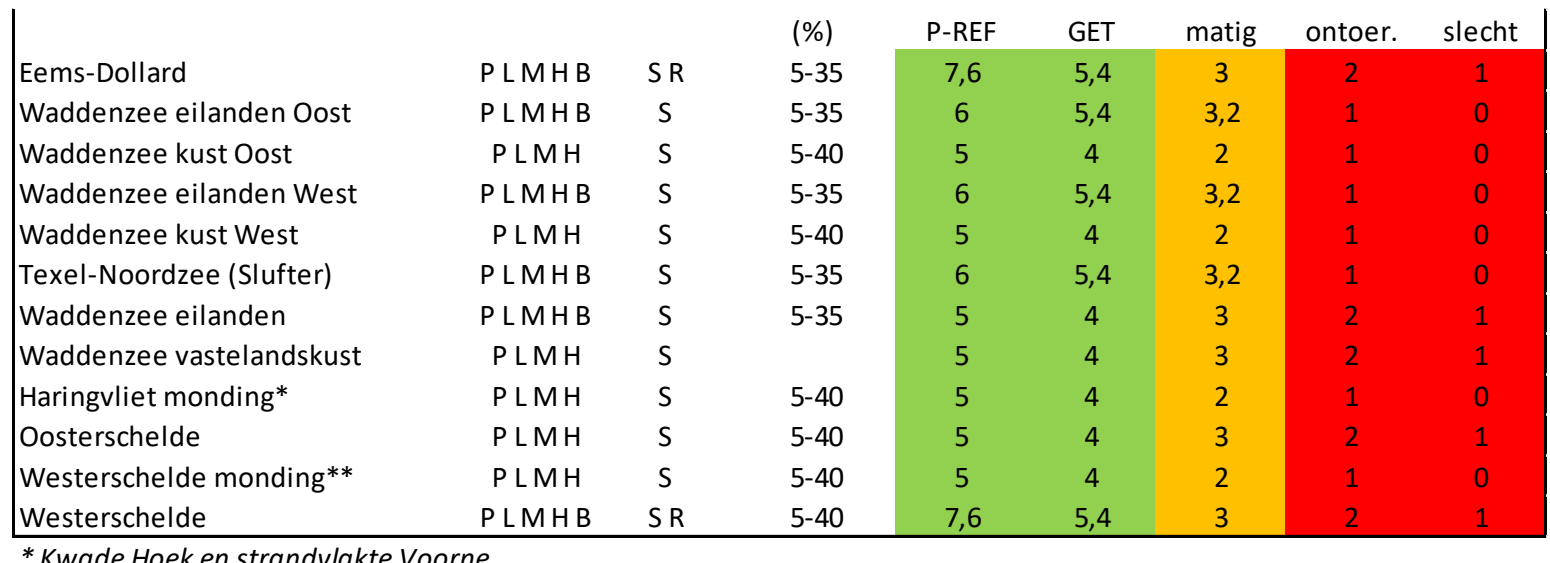

* Kwade Hoek en strandvlakte Voorne

** Het Zwin en Verdronken Zwarte Polder

De gebruikte bronnen in de 2019-rapportage voor de oppervlaktes van de verschillende zones (incl. climax-begroeiingen) zijn:

- Jentink (2018) voor het Waddengebied

- Jentink (2016) voor de Oosterschelde

- $\quad$ Reitsma \& de Jong (2018) voor de Westerschelde

- $\quad$ Tolman \& Pranger (2014) voor de Kwade Hoek

- $\quad$ Reitsma \& de Jong (2015) voor het Zwin en de Verdronken Zwarte Polder

Voor Krammer-Volkerak, Grevelingen, Yerseke-Kapelse Moer, Wormer- en Jisperveld, en Oosterschelde binnendijks (inlagen) zijn geen recente oppervlakte-gegevens voorhanden. Dit zijn alle binnendijkse terreinen, die geen rol spelen in de beoordeling voor de KRW, en om die reden zijn geen zoneringseisen vastgesteld. Voor de eerste drie van deze gebieden is op basis van expert-kennis een beoordeling van de kwaliteit van de binnendijkse schorren gemaakt in rood, oranje en groen. De andere gebieden zijn niet meegenomen in de analyse; ze bevatten samen minder dan $1 \%$ van de totale oppervlakte van beide habitattypen.

De resultaten per gebied zijn weergegeven in Tabel 4.3. Op basis van de totale kwelder kan hiermee het $\%$ berekend worden dat in goede, matige en slechte conditie is. Voor habitattype 1330 zijn de berekende percentages goed/matig/slecht (voor de totale kwelder!) gecorrigeerd naar de gerapporteerde totaal oppervlakte aan het habitattype. Na de correctie leverde dit de volgende oppervlaktes op:

$$
\begin{array}{ll}
\text { - } & \text { Totaal 1330: } 108 \mathrm{~km}^{2} \\
\text { - } & \text { Goed 1330: } 14 \mathrm{~km}^{2} \\
\text { - } & \text { Matig 1330: } 68 \mathrm{~km}^{2} \\
\text { - } & \text { Olecht 1330: } 25 \mathrm{~km}^{2} \\
\hline
\end{array}
$$

In de rapportage (format $§ 6.1$ ) is de oppervlakte met matige kwaliteit meegeteld bij de maximale oppervlakte van zowel good condition als not good condition.

Voor de pionierzone (1310) is eenvoudigweg gekeken of de pionierzone voldoet aan de eis van 5-35\% of niet, wat per gebied alleen een score groen of rood oplevert (of onbekend=grijs). Dit leverde de volgende gerapporteerde waarden op: $25 \mathrm{~km}^{2}$ totaal oppervlakte, waarvan $21 \mathrm{~km}^{2}$ good condition (groen), 2 km² not good condition (rood), en $2 \mathrm{~km}^{2}$ unknown.

De waarden uit Tabel 4.3 zijn tevens omgerekend tot een index (=waarde goed $+0.5 *$ waarde matig). De trend van S\&F in de rapportage (format §6.4) is bepaald aan de hand van deze index-waarde. Voor de afgelopen drie rapportageperioden is de index-waarde respectievelijk: 56, 44 en 45 . Over de afgelopen zes jaar is de trend in S\&F daarmee stabiel voor habitattypen 1310 en 1330. 
Tabel 4.3 Maatlat beoordeling Structuur \& Functie voor de kwelderhabitattypen 1310 en 1330. Zie tekst voor toelichting.

\begin{tabular}{|c|c|c|c|c|c|c|c|}
\hline Periode & $1998-2003$ & & 2004-2009 & & $2010-2016$ & & Bron \\
\hline Waddenzee eiland, Waddenzee-zijde & 3359 & & 3435 & & 3876 & & Jentink 2018 \\
\hline Waddenzee vasteland & 3997 & & 3833 & & 4275 & & Jentink 2018 \\
\hline Eems-Dollard & 727 & & 745 & & 745 & & Jentink 2018 \\
\hline Buiten KRW (Waddenzee) & 104.75 & & 110.48 & & 149.61 & & Jentink 2018 \\
\hline Kwade Hoek/Voorne & 246 & & 246 & & 251.4 & & Pranger \& Tolman 2014 \\
\hline Zwin & 24.6 & & 24.6 & & 37.3 & & Reitsma \& De Jong 2015 \\
\hline Zwarte Polder & 17.4 & & 17.4 & & 17.4 & & Reitsma \& De Jong 2015 \\
\hline \multicolumn{8}{|l|}{ Binnendijkse gebieden* } \\
\hline Ijsselmeergebied & & & & & & & opp. zeer gering \\
\hline Yerseke-Kapelse Moer & 51 & & 51 & & 51 & & expert beoordeling \\
\hline Oosterschelde-binnendijks & 182 & & 182 & & 182 & & expert beoordeling \\
\hline
\end{tabular}

Aanvullend op bovengenoemde methode, die gebaseerd is op monitoring en analyses die ook voor de KRW worden uitgevoerd, zijn de volgende indicatoren meegenomen:

- voor het eindoordeel van S\&F van 1310 en 1330 is ook de score van de typische soorten meegewogen (zie §4.5.2). Die score is FV (groen) voor habitattype 1310, en U1 (oranje) voor habitattype 1330 .

- $\quad$ voor het eindoordeel van S\&F van 1310 is ook een NDFF-analyse (zie §4.5.1) van soorten uitgevoerd voor subtype B (subtype A heeft te weinig kenmerkende soorten). Dit leverde een score U1 op. Deze score is niet doorslaggevend geweest, omdat het subtype B slechts een klein deel van habitattype 1310 beslaat.

Voor de beoordeling van S\&F van 1320 is een expert-oordeel gebruikt, waarbij de kwaliteit positief wordt beoordeeld indien de inheemse soort Spartina maritima aanwezig is, of eventueel de kruising Spartina $x$ townsendii. Van de gerapporteerde $7.5 \mathrm{~km}^{2}$ is deze soort of de hybride naar schatting in hoogstens $0.1 \mathrm{~km}^{2}$ aanwezig. De recente (her)ontdekking van deze typische soort van 1320 (die als uitgestorven werd beschouwd), is beoordeeld als een positieve trend in de landelijke score van S\&F van habitattype 1320 .

\subsubsection{Aquatische habitattypen (3110-3260)}

De beoordeling van de Structuur \& Functie van aquatische habitattypen is zoveel mogelijk gebaseerd op monitoringsdata die voor de Kader Richtlijn Water wordt ingezameld, waarbij de beoordeling zoveel mogelijk aansluit bij de maatlatten van de KRW. Problemen bij deze 'afstemming' zijn echter dat:

- De HR-rapportage landelijk wordt uitgevoerd, terwijl KRW-rapportages op gebiedsniveau spelen (voor waterlichamen);

- De definities van aquatische habitattypen en KRW-waterlichamen niet overeenkomen: in veel gevallen behoren alleen de met specifieke waterplanten begroeide delen van een waterlichaam tot het habitattype;

- Voor een deel van de aquatische habitattypen de data die ten grondslag ligt aan de KRWrapportage niet makkelijk voorhanden is;

- De aquatische habitattypen relatief dynamisch zijn, waarbij de voorkomens in gebieden kunnen gaan schuiven; het kan daarom nodig zijn om in de toekomst andere waterlichamen op te nemen in de S\&F-beoordeling, of nu gebruikte waterlichamen eruit te laten.

Uiteindelijk is alleen voor de habitattypen 3140 (Kranswierwateren) en 3150 (Meren met krabbenscheer en fonteinkruiden) de rapportage voor de Habitatrichtlijn sterk gebaseerd op de KRWdata. Een toelichting wordt hier gegeven voor de werkwijze bij habitattype H3140. De analyse van de S\&F voor H3150 verloopt op dezelfde wijze.

\section{Voorbeeld werkwijze H3140 en H3150}

De natuurlijke wateren van het IJsselmeergebied vallen binnen het KRW-type M21, Grote diepe gebufferde meren, die van de laagveenplassen binnen M27, Matig grote ondiepe laagveenplassen 
(Stowa 2007). Het type M21 is het meest relevant voor habitattype 3140 en 3150 , en wordt hier gebruikt bij de verdere toelichting. Voor het type M21 zijn KRW-maatlatten opgesteld voor de elementen fytoplankton, overige waterplanten, macrofauna, vis, fysisch-chemische toestand, en hydromorfologie. Voor de Natura 2000-rapportage wordt bij het bepalen van structuur \& functie van H3140 en H3150 aangesloten bij de deelmaatlat 'Overige waterplanten' van watertype M21 (onderdeel van 'Meren en rivieren'). Deze omvat twee verdere deelmaatlatten, één voor de Abundantie en één voor de Soortensamenstelling.

De door Rijkswaterstaat en waterschappen ingewonnen KRW-gegevens worden gebruikt bij de beoordeling. Deze gegevens geven de ecologische toestand per waterlichaam weer in de categorieën goed, matig en slecht/ontoereikend. Bij de KRW zijn maatlatten ontwikkeld voor verschillende typen waterlichamen. De maatlatscores liggen altijd tussen 0 en 1, waarbij referentiecondities gelijkgesteld worden aan 1. De overige waarden worden hierdoor gedeeld, waarmee de Ecologische Kwaliteits-Ratio (EKR) ontstaat. De EKR-scores worden gebruikt voor de Natura 2000-rapportage. De analyse van de structuur \& functie gebeurt vervolgens in drie stappen:

Stap 1. Op de eerste plaats wordt een selectie gemaakt van waterlichamen die relevant zijn voor habitattype 3140 en 3150 . Voor deze wateren wordt de oppervlakte ingeschat (op basis van topografische bestanden), zodat later een gewogen, landelijke score kan worden bepaald.

Stap 2. Voor de relevante wateren wordt bekeken of de toestand goed is (EKR > 0.6), matig (EKR 0.4$0.6)$ of slecht $(E K R<0.4)$. Voor waterlichamen waar geen score van voorhanden is, wordt deze als 'onbekend' aangegeven. De periode waaruit de gegevens gebruikt worden betreft de laatste zes jaar, waarbij de meest recente scores worden gebruikt in de analyse.

Stap 3. De oppervlakte van de wateren met goede, matige, slechte en onbekende toestand wordt gesommeerd en omgezet in percentages (\% EKR goed, matig, slecht, onbekend). Deze percentages worden vervolgens verrekend met de totale landelijke oppervlakte van het habitattype, zoals dat is gerapporteerd. ${ }^{4}$ Tenslotte worden de waarden die onder $\S 6.1$ gerapporteerd moeten worden als volgt bepaald:

oppervlakte goed $($ minimum $)=$ landelijke oppervlakte $* \%$ EKR goed oppervlakte goed $($ maximum $)=$ landelijke oppervlakte $*$ (\% EKR KR goed $+\%$ EKR matig) oppervlakte niet-goed (minimum) $=$ landelijke oppervlakte $* \%$ EKR slecht oppervlakte niet-goede $($ maximum $)=$ landelijke oppervlakte * (\% EKR slecht + \% EKR matig) oppervlakte onbekend (minimum) $=$ landelijke oppervlakte $* \%$ EKR onbekend oppervlakte onbekend (maximum) $=$ landelijke oppervlakte $* \%$ EKR onbekend

\section{Resultaten}

De voorkomens van habitattypen 3140 en 3150 liggen merendeels in grote wateren die onder beheer van Rijkswaterstaat vallen, zoals het IJsselmeer (m.n. langs Friese kust), Markermeer (IJmeer, Gooimeer), Veluwemeer, Nuldernauw en Zwarte Meer. Daarbuiten zijn met name de voorkomens in laagveengebieden nog van enige omvang (o.a. Botshol, Vinkeveense Plassen, Wieden, Weerribben). Van de relevante gebieden zijn de geschatte oppervlaktes en EKR-waarden en beoordeling weergegeven in Tabel 4.4 (voor H3140) en Tabel 4.5 (voor H3150).

\footnotetext{
${ }^{4}$ Bedenk dat de hier gebruikte data over waterlichamen aan de ene kant een steekproef vormt uit alle voorkomens van het habitattype, en aan de andere kant deels een grotere oppervlakte betreft dan strikt de oppervlakte van het habitattype binnen het waterlichamen.
} 
Tabel 4.4 Waterlichamen die een rol hebben gespeeld bij de beoordeling van Structuur \& functie van habitattype 3140, met EKR-score, beoordeling en oppervlakte.

\begin{tabular}{|lccc|}
\hline H3140 & $\begin{array}{c}\text { 2017 rapportage } \\
\text { (2014- 2016) }\end{array}$ & Oordeel & Oppervlakte (ha) \\
ljsselmeer-Friese ljsselmeerkust & 0.40 & matig & 6481 \\
Wieden & & $\begin{array}{c}\text { onbekend } \\
\text { onbekend }\end{array}$ & 3319 \\
Weerriben & & goed & 1737 \\
Zwarte Meer & 0.61 & goed & 6578 \\
Veluwe randmeren / oost & 0.67 & onbekend & 3844 \\
Randmeren zuid & & matig & 352 \\
Markermeer-IJmeer & 0.50 & onbekend & 757 \\
Markermeer-Gouwzee & & goed & 342 \\
Naardermeer & 0.64 & slecht & 180 \\
Botshol & 0.20 & onbekend & 572 \\
Nieuwkoopse Plassen & & onbekend & 639 \\
Vinkeveense Plassen & & ontoereikend & 263 \\
Ankeveense Plassen & 0.24 & ontoereikend & 76 \\
Kortenhoefse Plassen & 0.32 & ontoereikend & 177 \\
Molenpolder + Tienhovense plas & 0.37 & ontoereikend & 197 \\
Spiegelplas & 0.38 & ontoereikend & 45 \\
Terra Nova & 0.23 & matig & 77 \\
Waterleidingplas & 0.58 & matig & 228 \\
Wijde Blik & 0.50 & & $\mathbf{2 8 0 2 4}$ \\
Som oppervlakte & & & \\
\hline
\end{tabular}

Op basis van de gegevens uit Tabel 4.3 heeft van de oppervlakte van $118 \mathrm{~km}^{2}$ van $\mathrm{H} 3140$ in totaal $31 \%\left(37 \mathrm{~km}^{2}\right)$ een goede toestand, 25,5\% (30 $\left.\mathrm{km}^{2}\right)$ een matige toestand, 3,3\% (4 $\left.\mathrm{km}^{2}\right)$ een ontoereikend of slechte toestand, en $40 \%\left(47 \mathrm{~km}^{2}\right)$ een onbekende toestand.

Door ook voor een eerdere periode dezelfde berekening uit te voeren kan de trend in oppervlakte met goede kwaliteit worden bepaald. Deze is vergeleken met de periode 2010-2012 toegenomen, echter alleen doordat er voor een gebied waar geen informatie voor was (Zwarte Meer), data is bijgekomen. $\mathrm{Er}$ is dus feitelijk sprake van een stabiele trend. 
Tabel 4.5 Waterlichamen die een rol hebben gespeeld bij de beoordeling van Structuur \& functie van habitattype 3150, met EKR-score, beoordeling en oppervlakte.

\begin{tabular}{lccc}
\cline { 2 - 2 } H3150 & EKR & Opp. (ha) \\
ljsselmeer-Friese ljsselmeerkust & 0.29 & 6481 \\
Wieden & onbekend & 3319 \\
Weerribbenen & onbekend & 2137 \\
Zwarte Meer & 0.33 & 1760 \\
Veluwe randmeren / oost & 0.55 & 6578 \\
Markermeer-IJmeer & 0.56 & 352 \\
Markermeer-Gouwzee & 0.56 & 757 \\
Naardermeer & 0.6 & 342 \\
Botshol & 0.6 & 180 \\
Nieuwkoopse Plassen & 0.5 & 572 \\
Ankeveense Plassen & 0.6 & 263 \\
Kortenhoefse Plassen & 0.55 & 76 \\
Molenpolder + Tienhovense plas & 0.6 & 177 \\
Spiegelplas & 0.6 & 197 \\
Terra Nova & 0.51 & 45 \\
Waterleidingplas & 0.6 & 77 \\
Wijde Blik & 0.54 & 228 \\
Loosdrechtse plassen & 0.6 & 841 \\
Gelderse Poort & 0.45 & 410 \\
IJssel + Rijntakken & & 875 \\
Rottige Meenthe & 0.4 & 521 \\
Oude Venen & 0.4 & 2296 \\
De Fluessen en Oude Gaasterbrekke & 0.6 & 66 \\
Linge & & 29240 \\
Totaal opp & &
\end{tabular}

Op basis van de gegevens uit Tabel 4.4 heeft van de oppervlakte van $38 \mathrm{~km}^{2}$ van $\mathrm{H} 3150$ in totaal $7 \%$ $\left(2.8 \mathrm{~km}^{2}\right)$ een goede toestand, $41 \%\left(15,4 \mathrm{~km}^{2}\right)$ een matige toestand, $28 \%\left(26,1 \mathrm{~km}^{2}\right)$ een ontoereikend of slechte toestand, en $24 \%\left(9,1 \mathrm{~km}^{2}\right)$ een onbekende toestand.

Voor H3150 is een andere data set gebruikt om de trend te beoordelen. Uit PQ-data van Waternet (grotendeels ongepubliceerd, zie figuur 4.2) blijkt dat er sprake is van een sterke achteruitgang van alle waterplanten (waaronder die van $\mathrm{H} 3150$ ) in het Utrechtse en Hollandse laagveengebied. Op basis van deze sterk negatieve trend, waarvan wordt verondersteld dat ze met name door de toename van exotische rivierkreeften wordt veroorzaakt (Roessink et al. 2010), is de trend voor H3150 negatief gescoord.

\section{Overige habitattypen}

Voor habitattype 3130 (Zwakgebufferde vennen) is de beoordeling van structuur \& functie gebaseerd op de NDFF-methode (zie §4.5.1) terwijl de trend is beoordeeld op basis van literatuurbronnen (o.a. Van Dam et al. 2014, 2017). Voor H3260 (Beken en rivieren met waterplanten) is alleen voor subtype A een analyse volgens de NDFF-methode uitgevoerd, maar omdat gegevens voor H3260B ontbraken, is de gehele oppervlakte als 'onbekend' gescoord. Ook voor H3160 (Zure vennen) ontbraken geschikte gegevens en is de oppervlakte als 'onbekend' ingevuld bij 6.1. Voor H3110 (Zeer zwakgebufferde vennen) is op basis van een eigen database met gegevens en expert-kennis een inschatting gemaakt van het aandeel met goede en slechte structuur \& functie. 

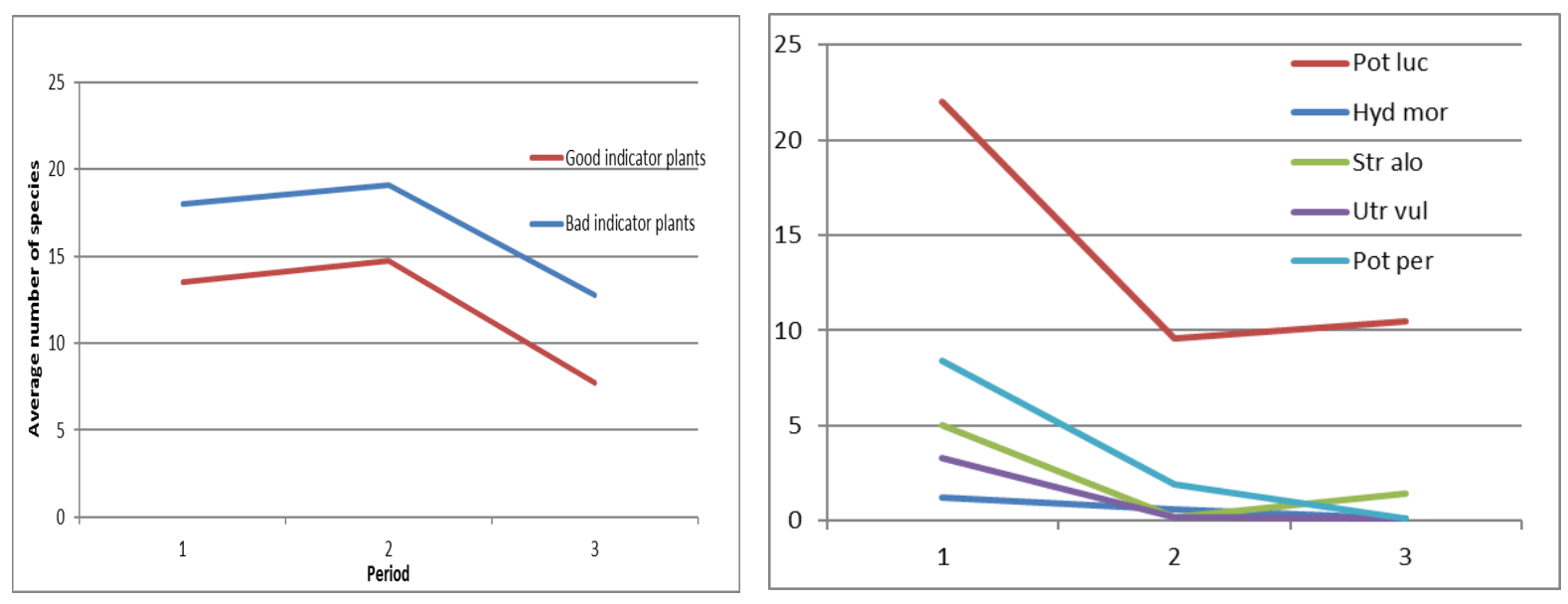

Figuur 4.2 Verandering in indicatorsoorten waterplanten (links) in de periodes 2006/2007 (1), 2010/2011 (2) en 2014/2015 (3), onderverdeeld naar indicatoren van goede en slechte waterkwaliteit. Rechts is de trend in gemiddelde bedekking van een aantal soorten in dezelfde periodes weergegeven (data Bart Specken, Waternet).

\title{
4.4 Werkwijze en data soortenrijke terrestrische typen
}

\author{
4.4.1 S\&F in strikte zin ('NDFF-methode')
}

\section{Achtergrond}

Voor steeds meer ecosystemen, zowel korte vegetaties als bossen, lijkt de structuur op gebiedsniveau op orde maar is sprake van zeer slecht functioneren: het decor is mooi maar steeds meer spelers haken af. Een lang bekend ecologisch knelpunt hierbij is fragmentatie en isolatie van populaties van plant- en diersoorten waardoor populatie-biologische processen niet meer goed functioneren (door o.a. inteelt, wegvallen van bestuivers, ontbreken van metapopulatiedynamiek) wat o.a. leidt tot 'extinction debt' (uitsterfschuld; Halley et al. 2017). Betrekkelijk recent onderzoek wijst bovendien op aanzienlijke knelpunten voor kleine fauna in relatie tot voedselkwaliteit van vegetaties en signaleert negatieve trends in voorkomen van insecten in het algemeen (Vogels et al. 2017; Kleijn et al. 2018). Hierbij zijn doorgaande verzuring en vermesting door $\mathrm{N}$-depositie belangrijke negatieve factoren, resulterend in een onbalans in nutriëntenbeschikbaarheid (De Vries et al. 2017; Van den Burg \& Vogels 2017). Doordat de beoordeling van natuurkwaliteit zich tot dusver sterk heeft gericht op structuurkenmerken en aandelen van kwalificerende vegetatietypen, is het slecht functioneren van habitattypen onvoldoende in beeld gekomen.

De conclusie uit bovenstaande is dat tal van habitattypen door combinaties van factoren (structuur, condities, processen) waarschijnlijk niet meer goed functioneren als leefgebied voor karakteristieke soorten. Dit zou moeten blijken uit de soortensamenstelling en uit trends. Deze conclusie vormt de basis van de werkwijze voor relatief soortenrijke habitattypen: laat karakteristieke soorten zelf aangeven of S\&F op orde is waarbij verspreidingsgegevens uit de NDFF als uitgangspunt dienen.

In grote lijnen is deze redenering als volgt uitgewerkt:

1. Voor alle relatief soortenrijke habitattypen is een lijst opgesteld van vaatplanten en mossen met een aanzienlijke binding aan het habitattype binnen de voor het habitattype relevante fysischgeografische regio's (FGRs). Dergelijke soorten worden aangeduid als 'karakteristieke soorten'. Voor beide soortgroepen is een binding met habitattypen goed te onderbouwen. Voor fauna is dit lastiger maar op termijn wel noodzakelijk om tot een goede beoordeling van S\&F te komen; een extra eis is dat van de betreffende soortgroepen fauna voldoende gegevens beschikbaar zijn. De eis van binding op niveau van FGRs is nodig om trends van soorten die voorkomen in verschillende landschappen te kunnen koppelen aan habitattypen. Zo kan een soort van kalkrijke groeiplaatsen een positieve trend te zien geven in de kalkrijke duinen, maar een negatieve in 
kalkgraslanden of kalkmoerassen. Deze verschillende trends zijn relevant voor de beoordeling van de betreffende habitattypen (binnen hun relevante FGRs).

2. De beoordeling van S\&F per habitattype volgt uit het voorkomen van karakteristieke soorten in km-hokken met het betreffende habitattype. Hierbij worden zowel de soortenrijkdom als veranderingen in soortenrijkdom betrokken (ten opzichte van eerdere rapportageperioden). Het voorkomen van habitattype per km-hok wordt ontleend aan vegetatiekarteringen (meestal beperkt tot Natura 2000-gebieden) en vegetatieopnamen in de LVD; deze verspreiding vormt ook de basis voor de rapportage van het verspreidingsgebied. Soortenrijke voorkomens van habitattype met overwegend stabiele of positieve trend in aanwezigheid van karakteristieke soorten worden beschouwd als habitattype in goede conditie. Relatief soortenarme voorkomens van habitattype met overwegend negatieve trend in aanwezigheid van karakteristieke soorten worden beschouwd als habitattype in niet-goede conditie. Deze werkwijze leidt tot groene, rode en overige (oranje) aanduidingen van km-hokken met habitattype. De fracties km-hokken met habitattype in goede en niet-goede conditie worden vervolgens betrokken op het landelijk areaal wat schattingen levert van de landelijke oppervlakten habitattype in goede en niet-goede conditie.

Evenals in voorgaande rapportages zijn voor de typen 4010, 9160 en 91 E0 beoordelingen uitgevoerd voor subtypen die voorkomen in verschillende FGRs. Deze beoordelingen zijn vervolgens samengevoegd tot één beoordeling volgens one out all out. Om beter inzicht te krijgen in de werking van de NDFF-methode zijn voor de overige habitattypen met subtypen, naast de hoofdtypen ook de subtypen apart beoordeeld (zie Bijlage 7).

De voorgestelde werkwijze geeft geen uitsluitsel over de oorza(a)k(en) van gesignaleerde verschillen in rijkdom van karakteristieke soorten en van trends in soortenrijkdom. Op landelijk niveau wordt hierover expliciet gerapporteerd onder 'Main pressures and threats' (Reporting format 7). De 'kleur' van een km-hok is echter goed te herleiden tot soortensamenstelling en eventuele veranderingen daarin wat als belangrijke input kan worden gebruikt voor nadere analyse op gebiedsniveau voor beheerplannen.

\section{Databronnen}

1. Lijsten van karakteristieke soorten vaatplanten en mossen per habitattype, opgesteld door Eddy Weeda, Rienk-Jan Bijlsma \& John Janssen (zie Bijlage 8). Het betreft soorten die binnen de voor het habitattype relevante fysisch-geografische regio's meer voorkomen in het betreffende habitattype dan in andere habitattypen. Er is dus sprake van een zekere binding van deze soorten aan habitattypen. De lijst is opgesteld uitgaande van (maar opnieuw beoordeelde) lijsten van typische soorten, kwaliteitssoorten van SNL-beheertypen en diagnostische soorten van kwalificerende vegetatietypen.

2. Verspreidingsgegevens per $\mathrm{km}$-hok van deze karakteristieke soorten van 32 relatief soortenrijke habitattypen voor (aanwezigheid) in de perioden 1999-2004, 2005-2010, 2011-2016 afzonderlijk. Deze data, inclusief korte- en langeretermijntrends (vanaf 2006 resp. vanaf 1990) binnen de relevante fysisch-geografische regio zijn aangeleverd door het CBS (Arco van Strien).

3. Verspreidingsgegevens van habitattypen op km-hokniveau, afkomstig uit habitatkaarten en vegetatieopnamen zoals beschikbaar in SynBioSys (zie §2.3 voor details).

\section{Data-analyse}

De stappen in de uitwerking van de NDFF-methode worden hieronder kort toegelicht:

1. Opslaan van verspreidingsgegevens van karakteristieke soorten in Access.

De lijst met karakteristieke flora per habitat(sub)type (zie Bijlage 8), verspreidingsgegevens van karakteristieke soorten per km-hok (alleen binnen de voor het habitattype relevante fysischgeografische regio's) en verspreiding van habitattypen per km-hok worden opgeslagen als tabellen in een Access-database waarin met een VBA-module alle verdere analyse plaatSvIndt (stappen 2-11).

2. Koppelen van verspreidingsgegevens van flora aan verspreiding van habitat(sub)typen per kmhok.

3. Bepalen van het aantal aangetroffen karakteristieke soorten per km-hok per periode voor elk habitat(sub)type (hcode); n1=aantal in periode 1, 1999-2004, n2=idem in periode 2, 2005-2010, n3=idem in periode 3, 2011-2016; het aantal gemeenschappelijke soorten voor de perioden 1-2 
(n12) en 2-3 (n23). Uitvoer naar tabel tblCrdCondition (hcode, crd, n1, n2, n3, n12, n23, rep6_1, rep6_3); voor rep6_1 en rep6_3 zie stappen 6 en 7. NB Deze tabel bevat uiteindelijk de uitvoer voor alle habitattypen met NDFF-werkwijze; de tabel kan via uitvoer naar Excel direct worden gekoppeld aan km-hokken in ArcGIS (zie stap 6).

4. Eenmalig beoordelen of km-hokken voldoende zijn onderzocht. Als criterium (voor stap 5) is gebruikt dat alleen hokken worden meegenomen in de analyse waarvoor geldt $n 12>1$ en $n 23>1$, wat betekent dat er meer dan één gemeenschappelijke soort aanwezig moet zijn voor de perioden 1-2 en 2-3. Voor de stappen 6 en 7 moet overeenkomstig gelden n23>1 resp. n12>1. Deze beslissingsregels zijn ingebouwd in de VBA-module.

5. Eenmalig opstellen van een beslissingsregel voor het onderscheid in hokken met relatief veel en relatief weinig karakteristieke soorten. Hokken met relatief veel soorten worden als goed of matig gescoord (afhankelijk van trends) en hokken met relatief weinig soorten als matig of slecht (idem). De gebruikte regel maakt gebruik van de per habitattype bepaalde mediaan (MEDSPP) van de verdeling van het cumulatieve aantal soorten over alle (voldoende onderzochte) hokken met habitattype uit periode 1999-2016. De cumulatieve verdeling fungeert als realistische baseline voor de beoordeling van karakteristieke soorten: wat is er over de gehele periode aangetroffen aan karakteristieke soorten binnen km-hokken met habitattype? NB De gevonden drempelwaarde zal ook voor komende rapportageperioden worden gebruikt.

6. Bepalen van 'condition unknown', 'good condition' en 'not good condition' per km-hok voor de huidige periode 3 (Reporting format 6.1). Uitvoer: veld rep6_1 in tblCrdCondition met de volgende waarden:

- $\quad$ rep6_1=1 als 'condition is not known' (n23 $\leq 1$, zie stap 4);

- rep6_1=4 als hok in 'good condition' (FV) d.w.z. als 1) hok relatief goed is onderzocht $(n 23>1), 2)$ het aantal soorten relatief groot is ( $n 3 \geq$ MEDSPP) en 3 ) het aantal soorten tussen perioden $2-3$ stabiel of toenemend ( $n 3 \geq n 2$ );

- rep6_1=2 als hok in 'not good condition' (U2) als 1 ) hok relatief goed is onderzocht ( $23>1)$, 2 ) het aantal soorten relatief gering is ( $n 3<$ MEDSPP) en 3 ) het aantal soorten tussen perioden $2-3$ is afnemend $(\mathrm{n} 3<\mathrm{n} 2)$;

- rep6_1=3 (U1) voor de overige goed doorzochte hokken (impliciet matig scorend).

Zie figuur 4.3 voor een voorbeeld van uitvoer op km-hokniveau.

7. Idem voor de vorige periode 2 als input voor de rapportage van 'short term trend of habitat area in good condition' (Reporting format 6.3). Hiertoe wordt stap 6 herhaald voor periode 2 (op basis van $\mathrm{n} 1, \mathrm{n} 2$ en n12). Uitvoer: veld rep6_3 in tblCrdCondition.

8. Bepalen van percentages hokken met onbekende, gunstige, zeer ongunstige en matig ongunstige conditie voor de huidige en vorige rapportageperiode (hier toegelicht aan de huidige rapportageperiode=periode 3 ; voor de vorige rapportageperiode moet rep6_1 worden vervangen door rep6_3):

- $\quad$ percentage 'onbekend' (\%X; voor periode 3): het aantal hokken waarvoor rep6_1=1 wordt betrokken op het totaal aantal voldoende onderzochte hokken (zie stap 4);

- $\quad$ percentage 'gunstig' (\%FV; idem): het aantal hokken waarvoor rep6_1=4 wordt betrokken op het totaal aantal voldoende onderzochte hokken minus het aantal onbekende hokken;

- $\quad$ percentage 'zeer ongunstig' (\%U2; idem): het aantal hokken waarvoor rep6_1=2 wordt eveneens betrokken op het totaal aantal voldoende onderzochte hokken minus het aantal onbekende hokken;

- $\quad$ percentage 'matig ongunstig' (\%U1; idem): 100 -\%FV - \%U2.

9. Rapporteren van oppervlakte habitattype met onbekende, goede en niet-goede conditie:

- $\quad$ Report 6.1c (Area where condition is not known): landelijke oppervlakte habitattype * fractie hokken 'onbekend' (\%X/100)

- $\quad$ Report 6.1a (Area in good condition): minimum $=$ landelijke oppervlakte habitattype $*$ fractie hokken 'gunstig' (\%FV/100) maximum $=$ landelijke oppervlakte habitattype $*$ (fractie hokken 'gunstig' + fractie hokken 'matig ongunstig') ((\%FV + \%U1)/100)

- $\quad$ Report 6.1b (Area in not good condition): minimum $=$ landelijke oppervlakte habitattype * fractie hokken 'zeer ongunstig' (\%U2/100) maximum = landelijke oppervlakte habitattype * (fractie hokken 'zeer ongunstig' + fractie hokken 'matig ongunstig') ((\%U2 + \%U1)/100) 
10. Rapporteren van eindoordeel S\&F in strikte zin volgens NDFF-methode. Hierbij worden dezelfde drempelwaarden gebruikt voor percentages gunstig, zeer ongunstig en matig ongunstig als gebruikt bij de vorige rapportage (Bijlsma \& Janssen 2014):

- $\quad \mathrm{SF}=\mathrm{FV}$ als $\% \mathrm{FV}>75$ en $\% \mathrm{U} 2 \leq 15$

- $\quad \mathrm{SF}=\mathrm{U} 2$ als \%U2 $>25$ and \%FV $<(\% \mathrm{U} 1+\% \mathrm{U} 2)$

- $\mathrm{SF}=\mathrm{U} 1$ in overige gevallen.

- $\quad$ SF wordt als onbekend gerapporteerd als \%X > 75 (NB Checken of dit werkelijk is toegepast) Zie Bijlage 7 voor de uitkomsten van deze stap.

11. Rapporteren van 'short term trend of habitat area in good condition' (Reporting format 6.3). De trend wordt gerapporteerd op grond van de verandering in percentage 'gunstige' km-hokken (\%FV) tussen de vorige en huidige rapportageperiode (zie stap 8) met een marge van 10\%:

- $\quad$ positief als percentage verandering $>+10$

- $\quad$ negatief als percentage verandering $<-10$

- $\quad$ stabiel in overige gevallen

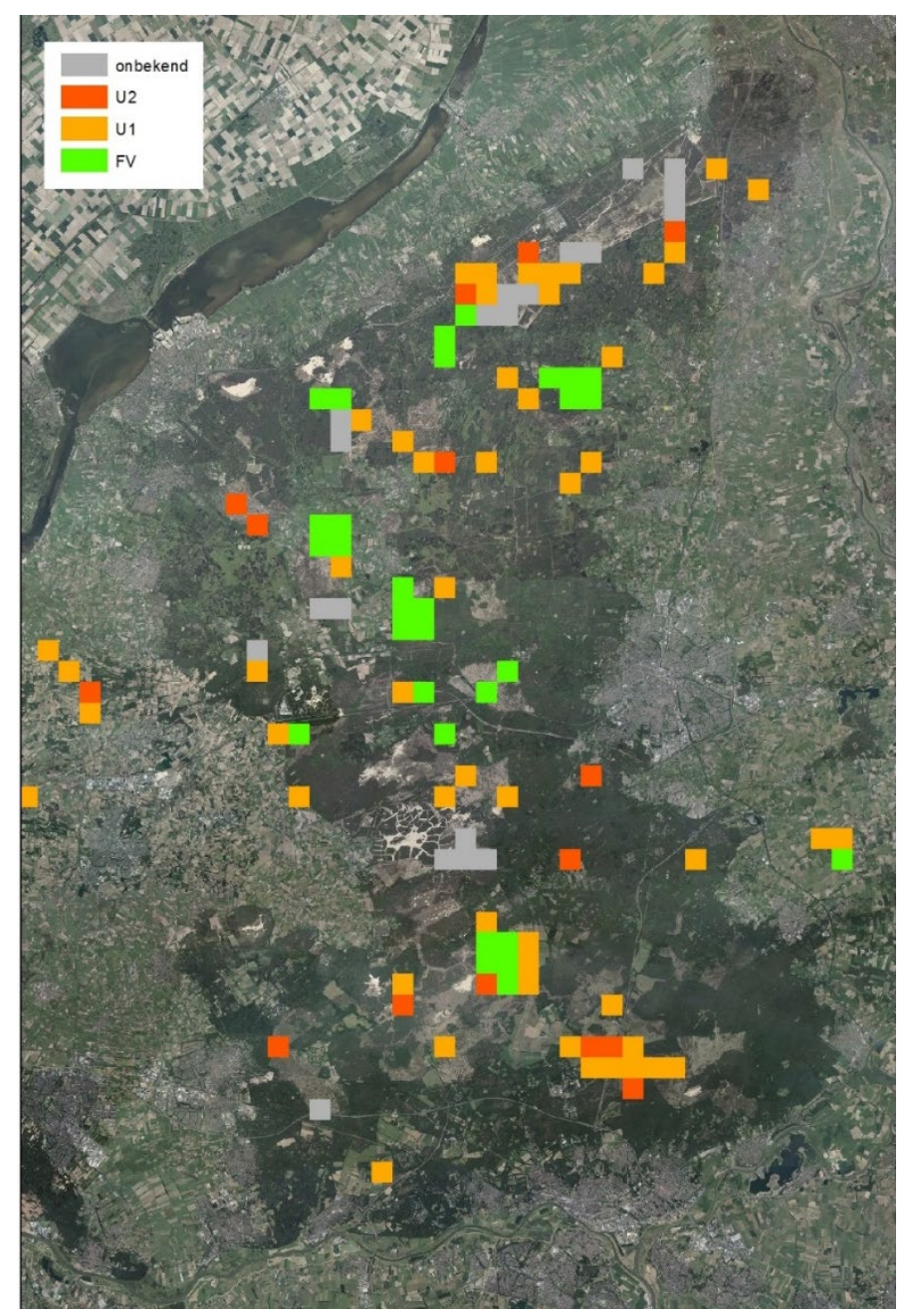

Figuur 4.3 Voorbeeld van de beoordeling van Structuur \& Functie met de NDFF-methode voor habitattype H4010A (Vochtige heiden) op km-hokniveau voor de Veluwe en omgeving. Zie tekst 'Data analyse' stap 6 voor toelichting.

\subsubsection{Typische soorten}

Voor het bepalen van de staat van instandhouding van typische soorten van habitattypen is dezelfde werkwijze gevolgd als in 2013 (Bijlsma \& Janssen 2014), waarbij is uitgegaan van de landelijke Rode Lijst-status van soorten (tabel 4.6).

Tabel 4.6 Toekenning van Rode Lijst-categorieën aan de staat van instandhouding van typische soorten: groen (TNB=thans niet bedreigd: $F V)$, oranje (GE=gevoelig, $K W=k w e t s b a a r: ~ U 1)$ en rood ( $B E=$ bedreigd, $E B=$ ernstig bedreigd; $V N=$ verdwenen: U2). 


\begin{tabular}{|c|c|c|c|c|c|c|}
\hline Trend: & klasse & & & & & \\
\hline stabiel of toegenomen & $0 /+$ & & GE-1 & TNB-2 & TNB-3 & TNB-4 \\
\hline matig afgenomen & $\mathrm{t}$ & & KW-5 & KW-6 & KW-7 & TNB-8 \\
\hline sterk afgenomen & $\mathrm{tt}$ & & BE-9 & BE-10 & $\mathrm{KW}-11$ & GE-12 \\
\hline zeer sterk afgenomen & $\mathrm{ttt}$ & & EB-13 & BE-14 & KW-15 & GE-16 \\
\hline maximaal afgenomen & $\mathrm{tttt}$ & VN-17 & & & & \\
\hline Zeldzaamheid: & & $\mathrm{X}$ & $\mathrm{ZZZ}$ & $\mathrm{zz}$ & $\mathrm{z}$ & $a$ \\
\hline & & afwezig & \begin{tabular}{|l|} 
zeer zeldzaam \\
\end{tabular} & zeldzaam & vrij zeldzaam & algemeen \\
\hline
\end{tabular}

Ten opzicht van 2013 zijn de volgende Rode Lijst geactualiseerd: vogels (Van Kleunen et al. 2017), zoetwatervissen (Kranenbarg \& Spikmans 2013) en zoutwatervissen (Tien et al. 2016). Verder kon gebruik worden gemaakt van het definitieve manuscript van de nieuwe Rode Lijst dagvlinders gepubliceerd in 2019 (Van Swaay 2019).

De RL-status vaatplanten is voor enkele soorten aangepast aan de Virtuele Rode Lijst die door het CBS wordt geactualiseerd (versie september 2018, via Arco van Strien, CBS). Voor de huidige rapportage zijn door het CBS ook trends berekend van alle typische soorten voor twee perioden:

- $\quad$ Tlong: "trendheleperiode" (vanaf 1990)

- Tshort: "trendvanaf2006"

Op grond van deze trends kunnen RL-categorieën zonder negatieve trend $(0 /+)$ maximiaal één regel zakken in het RL-schema van tabel 4.6. Dit is alleen relevant voor de aanpassingen van TNB-2 (FV) naar KW-6 (U1), TNB-3(FV)> KW-7(U1) en voor TNB zonder meer (als geen nadere categorie bekend is). Voor deze aanpassing is het volgende criterium gehanteerd:

- $\quad$ trendvanaf2006=It en trendheleperiode=(It of null)

$\mathrm{RL}$-categorieën met matige of sterk negatieve trend ( $\mathrm{t} / \mathrm{tt}$ ) kunnen maximaal één regel stijgen in het $\mathrm{RL}$-schema. Dit is alleen relevant voor de aanpassingen van KW-6 (U1) naar TNB-2 (FV) en van KW-7 (U1) naar TNB-3 (FV) (trendcategorie t) en van BE-9 (U2) naar KW-5 (U1), van BE-10 (U2) naar KW-6 (U1) en van GE-12 (U1) naar TNB-8 (FV) (trendcategorie tt). Hierbij geldt het criterium:

- $\quad$ trendvanaf2006=gt en trendheleperiode=null (voor RL-categorieën met trend=t)

- $\quad$ trendvanaf2006=gt en trendheleperiode=gt (voor RL-categorieën met trend $t, t t)$

Voor soorten zonder RL-categorie (null) geldt trendheleperiode als uitgangspunt, indien deze gelijk is aan null dan trendvanaf2006. In alle andere gevallen blijft de RL-status ongewijzigd.

De aldus beschikbare RL-categorieën zijn volgens het kleurenschema van tabel 4.6 toegekend aan een staat van instandhouding. De percentages soorten \%FV, \%U1 en \%U2 zijn verwerkt tot een eindoordeel per habitat(sub)type op dezelfde wijze als in 2013 (zie §4.5.1 stap 10). Voor habitattypen met minder dan 12 soorten, is dit eindoordeel in principe niet gebruikt in de rapportage (waarbij de in $\S 4.5 .1$ stap 10 gebruikte drempelwaarde van $15 \%$ correspondeert met 2 soorten). De uitkomsten zijn opgenomen in Bijlage 7.

\subsection{Overige analyses ten behoeve van rapportage S\&F}

\subsubsection{Analyse S\&F voor soortenarme, terrestrische typen}

Er blijft een "restgroep" over van 15 soortenarme, terrestrische habitats waarvoor geen geschikte gegevens en beoordelingsmethodiek voor S\&F voorhanden zijn. Beoordeling vindt dan plaats op basis van expert-kennis, waarbij zo mogelijk aanvullende gegevensbronnen of recente publicaties als ondersteuning dienen.

Eén van de meer generieke bronnen die gebruikt is, zijn de scores 'degree of conservation' (behoudsstatus) van de Standard data Forms (SDFs) voor de Natura 2000-gebieden (Janssen et al. 2014). Deze gebiedsscores kunnen worden opgeschaald naar een landelijke beoordeling van structuur \& functie zoals in 2013 uitgevoerd (Bijlsma \& Janssen 2014). Hier zitten wel enkele haken en ogen aan. Op de eerste plaats wordt in de SDFs slechts één score per gebied wordt gegeven, wat bij grote gebieden (Veluwe, Waddenzee, Geuldal) een onjuist beeld geeft, aangezien er dan niet genuanceerd 
wordt naar aandeel habitattype in goede en minder goede staat. Op de tweede plaats zijn de definities van de Structuur \& Functie van de landelijke staat van instandhouding en de behoudsstatus op gebiedsniveau niet hetzelfde. Zo kan het functioneren in samenhang (als tegenhanger van 'versnippering') landelijk beoordeeld worden, maar op gebiedsniveau een heel andere betekenis hebben. En ten derde worden in zo'n opschaling gebieden buiten het Natura 2000-netwerk niet meegewogen.

Voor de habitattypen $2110,2140,2150,2160,2170,2310,3160,3260,5130,7150,7210$ en $91 D 0$ is aangegeven dat onbekend is welk deel van het habitattype in goede en slechte staat is. Voor deze typen is de hele oppervlakte als 'onbekend' gerapporteerd in §6.1 van het rapportageformat. Voor drie andere relatief soortenarme habitattypen wordt hieronder kort aangegeven welke (afwijkende) werkwijze is gebruikt voor de S\&F beoordeling.

\section{Slijkgrasvelden}

Voor dit habitattype is ervan uitgegaan dat de structuur \& functie alleen op orde is als de (inheemse) soort Spartina maritima aanwezig is. Deze soort is recent (her)ontdekt op (tenminste) twee plekken, namelijk langs de Oosterschelde en in het Krammer-Volkerak. Ook het voorkomen van de hybride met Spartina anglica (Spartina $x$ townsendii) kan als goede S\&F worden beschouwd.

\section{Zinkweiden}

Voor dit habitattype zijn op een aantal plagplekken herintroducties van kenmerkende soorten uitgevoerd (met materiaal uit België). Er zijn echter nog geen aanwijzingen dat deze soorten zich ook in het oorspronkelijke grasland weten te vestigen. Omdat de kenmerkende soorten in dit resterende grasland steeds meer achteruitgaan, is de hele (beperkte) oppervlakte beoordeeld als 'in not-good condition'.

\section{Kalktufbronnen}

Op basis van een recente studie van Ramaekers (2014) is het aandeel goed versus niet-goed gebaseerd op de bedekking van de kenmerkende mossen. Dit is een methode die herhaalbaar is, maar wel aangevuld zou moeten worden met informatie over kenmerkende macrofauna. Op basis van een onderzoek naar de waterkwaliteit (Smolders et al. 2014) is een negatieve trend gerapporteerd. Een nog recenter onderzoek laat zien dat van alle (in de studie) onderzochte kalktufbronnen in Europa, de waterkwaliteit in de Nederlandse bronnen het slechtst is (referentie). Deze informatie was voor de rapportage nog niet beschikbaar.

\subsubsection{Trend-informatie uit NEM PQ's}

De PQ's van het NEM-meetnet LMF (http://www.netwerkecologischemonitoring.nl) zijn gebruikt om trends te berekenen in diverse indicatoren, zoals verdroging, verzuring, eutrofiëring, successie (aandeel pioniersoorten, openheid, aandeel struweel/bos), soortenrijkdom, etc. Deze trend-gegevens zijn door het CBS automatisch berekend voor in totaal 41 indicatoren (Tabel 4.7), op basis van een selectie aan $\mathrm{PQ}^{\prime} \mathrm{s}$.

De selectie is uitgevoerd door alle opnamen van PQ's in tabellen te zetten en via een expert-oordeel PQ's aan habitattypen toe te delen. Indien een $P Q$ in één van de jaren waarin deze is opgenomen voldoet aan een habitattype, is die bij dat type meegenomen in de analyse. Het kan dus zijn dat de begroeiing van een PQ dat voor een habitattype is gebruikt in de loop der tijd niet meer tot het habitattype gerekend kan worden, of ontstaan is uit een begroeiing die niet tot het habitattype wordt gerekend. Het aantal geselecteerde PQ's per habitattype is weergegeven in Tabel 4.8. Voor de habitattypen die niet in deze tabel worden genoemd waren niet voldoende PQ's voorhanden om een analyse uit te voeren. 
Tabel 4.7 Nummers van de indicatoren die door het CBS geanalyseerd zijn voor de $P Q$ 's per habitattype

\begin{tabular}{|c|c|}
\hline \multicolumn{2}{|c|}{ indicator_nr indicator_naam } \\
\hline 4 & Bedekking_kruidlaag \\
\hline 1 & Bedekking_totaal \\
\hline 2 & Bedekking_boomlaag \\
\hline 3 & Bedekking_struiklaag \\
\hline 5 & Bedekking_moslaag \\
\hline 7 & Bedekking_onbegroeid \\
\hline 700 & EllenbergN_Gem \\
\hline 701 & EllenbergN_gewogen \\
\hline 800 & EllenbergV_Gem \\
\hline 900 & EllenbergZ_Gem \\
\hline 902 & EllenbergZ_gewogen \\
\hline 1200 & Soortenaantal \\
\hline 1202 & Soortenaantal_pioniers \\
\hline 1203 & Soortenaantal_struiken \\
\hline 1204 & Soortenaantal_bomen \\
\hline 1205 & Soortenaantal_kruiden \\
\hline 1206 & Soortenaantal_grassen \\
\hline 1207 & Soortenaantal_overblijvende \\
\hline 1208 & Soortenaantal_houtigen \\
\hline 1209 & Soortenaantal_zeldzamesoorten \\
\hline 1210 & Soortenaantal_RodeLijstSoorten \\
\hline 1212 & Soortenaantal_exoten \\
\hline 1221 & Soortenaantal_Insectenbestuivers \\
\hline 3000 & Heide_vergrassing \\
\hline 3100 & Heide_verbossing \\
\hline 3400 & Duinen_verstruiking \\
\hline 3700 & EllenbergT_Gem \\
\hline 3800 & EllenbergZt_Gem \\
\hline 3900 & Sombed_Insectenbestuivers \\
\hline 3902 & Sombed_pioniers \\
\hline 3905 & Sombed_kruiden \\
\hline 3906 & Sombed_grassen \\
\hline 3907 & Sombed_overblijvend \\
\hline 3908 & Sombed_houtigen \\
\hline 3909 & Sombed_zeldzamesoorten \\
\hline 3910 & Sombed_RodeLijstSoorten \\
\hline 3912 & Sombed_exoten \\
\hline 3915 & EllenbergL_Gem \\
\hline 3918 & Bossen_oud \\
\hline 3919 & EllenbergC_gem \\
\hline 4004 & Verhouding_gras_kruid \\
\hline
\end{tabular}


Tabel 4.8 Aantal PQ's dat per habitattype is gebruikt. Voor habitattypen die niet in deze lijst worden genoemd waren geen of te weinig $P Q$ 's beschikbaar. Voor sommige habitattypen is de analyse per subtype uitgevoerd.

\begin{tabular}{|c|c|c|}
\hline & \multirow{2}{*}{$\begin{array}{c}\text { aantal PQs } \\
419\end{array}$} \\
\hline & $\begin{array}{l}\text { Habitattype } \\
2130 \quad \text { Grijze duinen }\end{array}$ & \\
\hline \multicolumn{2}{|r|}{ Duinheiden met kraaihei } & 59 \\
\hline \multicolumn{2}{|r|}{ Duindoornstruwelen } & 54 \\
\hline \multicolumn{2}{|r|}{ Kruipwilgstruwelen } & 14 \\
\hline \multicolumn{2}{|r|}{ Duinbossen } & 362 \\
\hline $2190 B$ & Vochtige duinvalleien & 42 \\
\hline \multicolumn{2}{|r|}{ Vochtige duinvalleien } & 76 \\
\hline \multicolumn{2}{|l|}{2310} & 127 \\
\hline \multirow{2}{*}{\multicolumn{2}{|c|}{$\begin{array}{l}\text { Binnnenlandse kraaiheibegroeiingen } \\
\text { Zandverstuivingen }\end{array}$}} & 37 \\
\hline & Zandverstuivingen & 13 \\
\hline \multicolumn{2}{|r|}{ Vochtige heiden } & 116 \\
\hline \multicolumn{2}{|r|}{ Droge heiden } & 276 \\
\hline \multicolumn{2}{|r|}{$\begin{array}{l}\text { Jeneverbesstruwelen } \\
\text { Stroomdalgraslanden }\end{array}$} & 15 \\
\hline \multirow{2}{*}{\multicolumn{2}{|c|}{$\begin{array}{l}\text { Stroomdalgraslanden } \\
\text { Kalkgraslanden }\end{array}$}} & 60 \\
\hline & & 28 \\
\hline \multicolumn{2}{|r|}{ Heischrale graslanden } & 63 \\
\hline \multirow{2}{*}{6410} & Blauwgraslanden & 79 \\
\hline & Glanshaver- en vossenstaarthooilaı & 104 \\
\hline 7110 & Actieve hoogvenen & 20 \\
\hline \multirow{2}{*}{$\begin{array}{l}7140 \mathrm{~A} \\
7140 \mathrm{~B}\end{array}$} & Overgangs- en trilvenen & 21 \\
\hline & Overgangs- en trilvenen & 86 \\
\hline \multirow{2}{*}{$\begin{array}{l}7210 \\
7230\end{array}$} & Galigaanmoerassen & 7 \\
\hline & Kalkmoerassen & 10 \\
\hline 9110 & Veldbies-beukenbossen & 17 \\
\hline \multirow{2}{*}{$\begin{array}{l}9120 \\
9160 A\end{array}$} & Beuken-eikenbossen met hulst & 54 \\
\hline & Eiken-haagbeukenbossen & 9 \\
\hline \multirow{2}{*}{$\begin{array}{l}9160 \mathrm{~B} \\
9190\end{array}$} & Eiken-haagbeukenbossen & 18 \\
\hline & Oude eikenbossen & 13 \\
\hline 91D0 & Hoogveenbossen & 13 \\
\hline 91E0A & Vochtige alluviale bossen & 17 \\
\hline \multirow{2}{*}{$\begin{array}{l}91 \mathrm{E} 0 \mathrm{~B} \\
91 \mathrm{E} 0 \mathrm{C}\end{array}$} & Vochtige alluviale bossen & 16 \\
\hline & Vochtige alluviale bossen & 20 \\
\hline
\end{tabular}

De PQ-analyse is uitgevoerd met gegevens uit de periode 2006-2017. Dit betekent dat de meeste PQ's $4 \mathrm{x}$ waren opgenomen, en een deel $3 \mathrm{x}$. Het resultaat was per habitattype voor de indicatoren een toenemende of afnemende trend, of een onzekere trend. ${ }^{5}$ Deze zijn vervolgens op basis van expertkennis beoordeeld als zijnde positief (groen), negatief (oranje) of niet relevant of onbekend (grijs). Een voorbeeld (voor habitat-subtype 7140B) is weergegeven in Tabel 4.9. Op basis van het overwegend groen of oranje scoren van de indicatoren, is ingeschat of er sprake is van een positieve, negatieve of onbekende trend.

Deze gegevens zijn gebruikt als aanvullende informatie op andere indicatoren, aangezien ze alleen een trend geven en geen absolute aantallen goed/slecht.

\footnotetext{
${ }^{5}$ Bij nader inzien bleek dat een programmeerfout van CBS bij de trend labeling. Alle onzekere trends zijn eigenlijk stabiele trends.
} 
Tabel 4.9 Resultaten van de $P Q$-analyse voor habitat-subtype 7140B. Alhoewel veel indicatoren onbekend scoren, is op basis van het aantal oranje en groene scores overall een negatieve trend geoordeeld voor dit subtype.

\section{Habitattype 7140B}

\section{Indicator}

Bedekking_boomlaag

EllenbergN_Gem

EllenbergZ_Gem

Soortenaantal_kruiden

EllenbergC_gem

Bedekking_totaal

EllenbergN_gewogen

Soortenaantal_Insectenbestuivers

EllenbergT_Gem

Bedekking_moslaag

Soortenaantal

Soortenaantal_houtigen

Soortenaantal_RodeLijstSoorten

Sombed_overblijvend

Sombed_zeldzamesoorten

EllenbergL_Gem

Bedekking_struiklaag

Bedekking_kruidlaag

Bedekking_onbegroeid

EllenbergV_Gem

EllenbergZ_gewogen

Soortenaantal_pioniers

Soortenaantal_struiken

Soortenaantal_bomen

Soortenaantal_grassen

Soortenaantal_overblijvende

Soortenaantal_zeldzamesoorten

Soortenaantal_exoten

Heide_vergrassing

Heide_verbossing

Duinen_verstruiking

EllenbergZt_Gem

Sombed_Insectenbestuivers

Sombed_pioniers

Sombed_kruiden

Sombed_grassen

Sombed_houtigen

Sombed_RodeLijstSoorten

Sombed_exoten

Bossen_oud

Verhouding_gras_kruid
\# PQ's Significantie Trend

82

**

toename

82

82

82

82

82

82

82

82

afname

** afname

$* *$ afname

$* *$ afname

afname

afname

afname

onzeker

82

77

onzeker

onzeker

onzeker

onzeker

onzeker

onzeker

onzeker

onzeker

onzeker

onzeker

onzeker

onzeker

onzeker

onzeker

onzeker

onzeker

onzeker

onzeker

onzeker

onzeker

onzeker

onzeker

onzeker

onzeker

onzeker

onzeker

onzeker

onzeker

onzeker

onzeker

onzeker 
In totaal gaf de analyse voor één habitattype (7230) een positieve trend te zien (Tabel 4.10). Deze kalkmoerassen komen op zo'n 20 locaties voor en worden dan ook - met 10 PQ's - relatief goed afgedekt door het NEM PQ-netwerk. De positieve trend uit de NEM-PQ analyse is dan ook overgenomen in $§ 6.3$ van het rapportageformat. Voor zeven andere (sub)typen gaf de PQ-analyse een negatieve trend te zien, bij alle andere een onbekende trend. Deze scores zijn lang niet altijd direct overgenomen in de rapportage, omdat (i) deze analyses vaak gebaseerd zijn op een relatief klein aantal van de 41 indicatoren, en omdat (ii) andere analyses of informatie andere trends laten zien. Zo is bij de bossen bijvoorbeeld de trend in dood hout als relevant beoordeeld (zie §4.6.3) en zijn voor bijvoorbeeld heides met name de ontwikkelingen in de fauna van belang.

Tabel 4.10 Resultaten van de $P Q$-analyse voor alle habitat(sub)typen. Aangegeven is of de analyse als een positieve ( + ), negatieve $(-)$ of onbekende $(x)$ overall trend is beoordeeld. Bij twee (sub)habitats kon er geen analyse worden uitgevoerd $\left(^{*}\right)$.

\begin{tabular}{|c|c|c|}
\hline \multicolumn{2}{|c|}{ Habitattype } & Trend \\
\hline 2130 & Grijze duinen & $x$ \\
\hline 2140 & Duinheiden met kraaihei & $x$ \\
\hline 2160 & Duindoornstruwelen & $x$ \\
\hline 2170 & Kruipwilgstruwelen & $x$ \\
\hline 2180 & Duinbossen & + \\
\hline 2190B & Vochtige duinvalleien & $x$ \\
\hline $2190 C$ & Vochtige duinvalleien & - \\
\hline 2310 & Stuifzandheiden met struikhei & - \\
\hline 2320 & Binnnenlandse kraaiheibegroeiingen & $x$ \\
\hline 2330 & Zandverstuivingen & $x$ \\
\hline $4010 \mathrm{~A}$ & Vochtige heiden & $x$ \\
\hline 4030 & Droge heiden & - \\
\hline 5130 & Jeneverbesstruwelen & $x$ \\
\hline 6120 & Stroomdalgraslanden & $x$ \\
\hline 6210 & Kalkgraslanden & $*$ \\
\hline 6230 & Heischrale graslanden & $x$ \\
\hline 6410 & Blauwgraslanden & - \\
\hline 6510 & Glanshaver- en vossenstaarthooilaı & - \\
\hline 7110 & Actieve hoogvenen & $x$ \\
\hline $7140 \mathrm{~A}$ & Overgangs- en trilvenen & $x$ \\
\hline $7140 B$ & Overgangs- en trilvenen & - \\
\hline 7210 & Galigaanmoerassen & $x$ \\
\hline 7230 & Kalkmoerassen & + \\
\hline 9110 & Veldbies-beukenbossen & \\
\hline 9120 & Beuken-eikenbossen met hulst & $x$ \\
\hline $9160 \mathrm{~A}$ & Eiken-haagbeukenbossen & $x$ \\
\hline $9160 B$ & Eiken-haagbeukenbossen & $*$ \\
\hline 9190 & Oude eikenbossen & - \\
\hline 91D0 & Hoogveenbossen & - \\
\hline $91 \mathrm{EOA}$ & Vochtige alluviale bossen & $x$ \\
\hline 91EOB & Vochtige alluviale bossen & $x$ \\
\hline $91 \mathrm{EOC}$ & Vochtige alluviale bossen & $x$ \\
\hline
\end{tabular}

* analyse gaf geen resultaat

\subsubsection{Analyse S\&F met NBI-gegevens (bossen)}

i.s.m. Mart-Jan Schelhaas (WENR)

\section{Achtergrond}

$\mathrm{Er}$ is brede consensus dat de hoeveelheid dood hout een belangrijke indicator is voor de natuurwaarde van bossen (EEA 2012: SEBI-indicator 18). De meetpunten van de bosstatistieken MFV (3622 punten) en NBI (3658) vormen statistisch verantwoorde steekproeven van structuurkenmerken (incl. dood hout) van het Nederlandse bos (Dirkse et al., 2007; Schelhaas et al., 2014). Voor habitattypen bos die voldoende zijn vertegenwoordigd in de steekproef kan de gemeten hoeveelheid dood hout daarom worden gebruikt bij de landelijke beoordeling van Structuur \& Functie. In plaats van alleen de steekproefpunten te beschouwen die (in Natura 2000-gebieden) binnen kaartvlakken van habitattypen bos vallen, wordt ook een bredere verzameling punten beschouwd die karakteristiek zijn voor de landschappen waarin de betreffende habitattypen voorkomen, zoals bossen in het gehele duingebied 
in relatie tot $\mathrm{H} 2180$ en bossen op kwalificerende bodems van de hogere zandgronden en het heuvelland in relatie tot H9120/H9190. Dit is relevant omdat de van dood hout afhankelijke biodiversiteit geen sterke relatie heeft met specifieke habitattypen maar meer met dood hout aanwezig in het betreffende landschap (leefgebied).

Müller \& Bütler (2010) geven een review van drempelwaarden voor de beoordeling van de kwantiteit van dood hout in Europese bossen. Op grond hiervan is tabel 4.11 opgesteld. De drempelwaarden gelden voor hardhoutbossen, ongeacht bostype. Zie voor referentievoorraden ook Wijdeven in Jagers op Akkerhuis et al. (2005).

Tabel 4.11 Gehanteerde drempelwaarden voor de totale hoeveelheid dood hout bij de beoordeling van de structuur van bossen.

\begin{tabular}{ll} 
Toestand & $\begin{array}{l}\text { Hoeveelheid dood } \\
\text { hout }\left(\mathrm{m}^{3} / \mathrm{ha}\right)\end{array}$ \\
\hline Gunstig (FV) & $\geq 30$ \\
\hline Matig ongunstig (U1) & $15-30$ \\
\hline Zeer ongunstig (U2) & $<15$ \\
\hline
\end{tabular}

\section{Databronnen}

- $\quad$ Staand dood hout en liggend dood hout in $\mathrm{m}^{3} /$ ha afkomstig uit de twee meest recente bosstatistieken: NBI6 (2012-2013; Nederlandse Bosinventarisatie 6) en MFV (2001-2005; Meetnet Functievervulling Bos $=5^{\text {de }}$ bosstatistiek).

- Habitatkaart 2018 (zie §2.3).

\section{Data-analyse}

De stappen in de uitwerking worden hieronder kort toegelicht:

1. Een overlay van de steekproefpunten MFV en NBI met de habitatkaart in GIS geeft aantallen punten per habitattype binnen Natura 2000-gebieden.

2. Om ook steekproefpunten buiten deze gebieden te kunnen betrekken zijn de volgende selecties toegevoegd. Vervolgens is de representativiteit van de steekproeven beoordeeld:

- DU-extra (duinen aanvullend op H2180): alle steekproefpunten die vallen binnen FGR duinen. Deze verzameling representeert de duinbossen incl. $\mathrm{H} 2180$.

- HL-extra (veldbiesbeukenbos-landschap aanvullend op H9110): alle steekproefpunten die vallen binnen het veldbies-beukenboslandschap zoals begrensd door Hommel et al. (2018).

- HZ-TMK-extra (hogere zandgronden en heuvelland aanvullend op H9120 en H9190): voor alle 500x500 m gridcellen met een oude bosgroeiplaats binnen FGR hogere zandgronden en heuvelland (volgens Van Dorland et al. 2012) is het bodemtype met de grootste oppervlakte bepaald (volgens bodemkaart van Nederland 1:50,000). Als deze eenheid potentieel habitattype 9120 of 9190 betreft (volgens Bijlsma et al. 2010) dan zijn de steekproefpunten binnen deze cellen beschouwd als representatief voor landschappen met habitattype 9120 en/of 9190 inclusief punten in deze landschappen die ook al op grond van de habitatkaart tot 9120 of 9190 worden gerekend.

- HZ-extra: als HZ-TMK-extra maar zonder eis aan leeftijd van de bosgroeiplaats.

- RI-extra (rivierengebied aanvullend op H91E0A): alle steekproefpunten die vallen binnen de ecoserie RiLS (stroombedding laaglandrivieren) volgens Van Delft et al. (Landschapssleutel); hiermee worden slechts drie punten toegevoegd aan de punten die binnen H91E0A vallen.

- Op grond van deze overlays blijken H2180, H9110, H9120, H9160B en H9190 voldoende representatief te zijn vertegenwoordigd door meetpunten van MFV/NBI. H9160A en H91E0C zijn, gezien hun landelijke verspreiding, zeer onvoldoende vertegenwoordigd (wat ook lastig is gezien hun versnipperd areaal). In de hardhoutooibossen H91E0B en H91F0 liggen geen steekproefpunten. H91E0A betreft overwegend meetpunten in de Biesbosch en evenals H91D0 is het een bostype met vooral zachthoutsoorten waarvoor referentiewaarden voor dood hout niet goed bekend zijn. Conclusie: de NBI-methode wordt alleen uitgevoerd voor $\mathrm{H} 2180$, H9110, H9120, H9160B en H9190.

3. Voor de aldus geselecteerde punten zijn gemiddelde en mediane voorraden totaal dood hout per plot berekend in $\mathrm{m}^{3}$ /ha conform de NBI-documentatie (Schelhaas et al., 2014) waarbij in eerste instantie onderscheid is gemaakt in liggend en staand dood hout en in inheems loofhout, inheems 
naaldhout (grove den) en overig dood hout (inclusief van onbekende soort). Verschillen in gemiddelde voorraden tussen MFV en NBI zijn getoetst (R Wilcox-test, vanwege scheve verdelingen) als indicatie voor trend. Verder is de gemiddelde hoeveelheid voor de NBI-periode beoordeeld ten opzicht van de drempelwaarden voor dood hout (mean NBI) en is parametervrij getoetst of de gemiddelde voorraad voor NBI gelijk over groter is dan voor MFV (trend MFV-NBI). Tot slot worden aantallen plots met slechte, matige en goede hoeveelheden dood hout weergegeven voor MFV en NBI . De uitkomsten zijn opgenomen in Bijlage 8.

\section{Resultaten}

- H2180. Voor duinbossen is er nauwelijks verschil in uitkomsten voor punten die binnen habitattype vallen ( $n=$ ca 50 ) en bossen van het gehele duingebied ( $n=c a 110)$. Dit sluit aan op het zeer heterogene karakter van $\mathrm{H} 2180$ dat in feite alle inheems loofbos in het duingebied omvat. De voorraden dood hout zijn laag ( $<15 \mathrm{~m}^{3} / \mathrm{ha}$ ) maar vertonen een significant positieve trend.

- H9110. Het dood hout van de veldbiesbeukenbossen wordt beschreven met slechts 6-8 punten die echter wel een goede spreiding hebben over de kleine oppervlakte in zuidoostelijk Zuid-Limburg. De habitatkaart moet nog worden aangepast aan de inzichten van Hommel et al. (2018) waardoor het aantal punten nog iets zal toenemen. De voorraad dood hout is zeer laag en vertoont geen stijgende lijn.

- H9120 en H9190. De uitkomsten voor beide habitattypen zijn overeenkomstig zowel in voorraad als positieve trend. Dit is gezien de grote verwantschap van beide typen in structuur en landschappelijke samenhang niet onverwacht. Opvallend is dat het betrekken van relevant landschap (oude bosgroeiplaatsen op kwalificerende bodems binnen FGR hogere zandgronden en heuvelland) buiten de Natura 2000-gebieden een halvering te zien geeft in de voorraden dood hout (van matig naar slecht); op oude bosgroeiplaatsen (HZ-TMK-extra) is deze daling even groot als op jongere bosgroeiplaatsen (HZ-extra). Voor de meetpunten in habitattype geldt voor zowel H9120 als H9190 dat 10-15\% van de meetpunten een goede kwaliteit heeft (d.w.z. met voorraad groter dan $30 \mathrm{~m}^{3} / \mathrm{ha}$ ).

- H9160B. De eiken-haagbeukenbossen van het heuvelland geven overall een stabiele, matige kwaliteit te zien. Vanwege onzekerheden bij de interpretatie van habitatkaarten voor dit type is weinig te zeggen over de relevantie van deze uitkomst.

- Deze resultaten zijn meegenomen bij de beoordeling van Structuur \& Functie conform het beoordelingsschema in Bijlage 6. 


\subsection{Resultaten}

Deze paragraaf geeft een toelichting op de beoordeling van de structuur \& functie van habitattypen waarvoor de NDFF-methode is gebruikt en voor zover de staat van instandhouding is veranderd ten opzichte van 2013 (Tabel 4.12). De uitkomsten van de overige habitattypen zijn al besproken in $\S 4.3$ (mariene typen 1110 - 1170), §4.4.1 (kweldertypen 1310 en 1330), §4.4.2 (aquatische typen 3140 en 3150 ) en $\S 4.6 .1$ voor een restgroep van 15 soortenarme habitattypen.

Tabel 4.12 Toelichting bij verandering van de staat van instandhouding van Structuur \& Functie in 2019 ten opzichte van de vorige rapportage (2013).

\begin{tabular}{|c|c|}
\hline Habitattype & toelichting \\
\hline 2120 Witte duinen & \multirow{3}{*}{$\begin{array}{l}\text { Op grond van S\&F in strikte zin (U1 voor beide rapportageperioden) en } \\
\text { Typische soorten (U1, met positieve trend) zou de SvI in feite U1 moeten } \\
\text { zijn. Deze TS-score is echter sterk gebaseerd op de Rode Lijst-status van } \\
\text { een aantal paddenstoelen in de helmduinen, die gemiddeld slechter } \\
\text { scoren dan andere karakteristieke soorten. Van die paddenstoelen is } \\
\text { inmiddels door gericht inventariseren gebleken dat ze meer voorkomen } \\
\text { dan eerder werd gedacht (zie bijv. www.verspreidinjgsatlas.nl), wat de } \\
\text { reden is om deze TS score omhoog bij te stellen naar FV. De totale S\&F- } \\
\text { score is op basis hiervan ook als FV beoordeeld. }\end{array}$} \\
\hline 2013 & \\
\hline 2019 & \\
\hline 2130 Grijze duinen & \multirow{3}{*}{$\begin{array}{l}\text { De U1-score voor de S\&F in strikte zin voor de subtypen A en C heeft } \\
\text { zwaarder gewogen dan de U2 voor subtype B. Subtype B2 kan feitelijk } \\
\text { niet goed beoordeeld worden vanuit de (veel meer) karakteristieke } \\
\text { soorten van subtypen A en C. }\end{array}$} \\
\hline 2013 & \\
\hline 2019 & \\
\hline 3270 Slikkige rivieroevers & \multirow{3}{*}{$\begin{array}{l}\text { Expert oordeel heeft S\&F in strikte zin U1 overruled vanwege de sterke } \\
\text { uitbreiding in het rivierengebied (positieve trend) en het zeer dynamische } \\
\text { karakter (jaar op jaar variatie in aantal karakteristieke soorten). }\end{array}$} \\
\hline 2013 & \\
\hline 2019 & \\
\hline $\begin{array}{l}6110 \text { Pionierbegroeiingen } \\
\text { op rotsbodem }\end{array}$ & \multirow[t]{3}{*}{ S\&F in strikte zin is U1 voor zowel 2019 als (herberekend) 2013.} \\
\hline 2013 & \\
\hline 2019 & \\
\hline 6120 Stroomdalgraslanden & \multirow{3}{*}{$\begin{array}{l}\text { S\&F in strikte zin is U2 voor zowel } 2019 \text { als (herberekend) 2013. Typische } \\
\text { soorten is U2. }\end{array}$} \\
\hline 2013 & \\
\hline 2019 & \\
\hline 6410 Blauwgraslanden & \multirow{3}{*}{$\begin{array}{l}\text { S\&F in strikte zin is U1 voor zowel } 2019 \text { als (herberekend) } 2013 \text {, } \\
\text { waarschijnlijk dankzij de vele herstelprojecten. Typische soorten blijft wel } \\
\text { U2. }\end{array}$} \\
\hline 2013 & \\
\hline 2019 & \\
\hline 6510 Glanshaver- en & \multirow{4}{*}{$\begin{array}{l}\text { Subtype A: S\&F in strikte zin is U2 voor zowel } 2019 \text { als (herberekend) } \\
\text { 2013. Subtype B: S\&F in strikte zin U2 voor } 2019 \text { ten opzichte van U1 } \\
\text { (herberekend) in 2013. Voor gehele type is Typische soorten U2. }\end{array}$} \\
\hline Vossenstaarthooilanden & \\
\hline 2013 & \\
\hline 2019 & \\
\hline 9190 Oude eikenbossen & \multirow{3}{*}{$\begin{array}{l}\text { S\&F in strikte zin is U2 voor zowel } 2019 \text { als (herberekend) } 2013 . \\
\text { Bovendien negatieve trend in FV area. }\end{array}$} \\
\hline 2013 & \\
\hline 2019 & \\
\hline
\end{tabular}

\subsection{Discussie}

Voor de rapportage van structuur \& functie zijn nieuwe uitgangspunten geformuleerd die moeten garanderen dat de beoordeling van deze parameter ook in de toekomst navolgbaar kan plaatSvInden met actuele gegevens (zie $\S 4.2 .1$ ). Hiervoor is het nodig gebleken voor groepen van habitattypen verschillende methoden te ontwikkelen die aansluiten op verschillende datastromen. De belangrijkste bronnen zijn gerelateerd aan KRM, KRW, NDFF, NBI en NEM. Voor elk van de hiermee samenhangende werkwijzen zijn verbeterpunten in beeld, alsook voor het gebruik van typische soorten. Deze dienen in 
de periode tussen deze en de volgende rapportage nader te worden uitgewerkt, zodat de data, werkwijze en maatlatten voor de volgende rapportage van de volgende periode verder verbeterd zijn.

\section{Kaderrichtlijn Marien (KRM)}

Voor H1110 en H1170 is een monitoringsprogramma opgezet (gebaseerd op meetpunten waar de samenstelling van de benthos wordt omgezet in een index BISI). Deze moet voor de volgende rapportage voldoende gegevens opleveren om trends te analyseren. Wel bevat deze methodiek nog geen formele beoordeling van het aandeel goed/niet-goed. Zo'n maatlat kan het beste in afstemming met de methodes en rapportages van de MSFD worden ontwikkeld. Ook dient de monitoring van $\mathrm{H} 1110$ uitgebreid te worden met $\mathrm{H} 1110 \mathrm{~A}$ in de Waddenzee.

Voor de andere drie mariene habitattypen 1130, 1140 en 1160 wordt momenteel ook gewerkt aan de inwinning van gegevens ten behoeve van een benthos-index, zoals de BISI. Een maatlat voor beoordeling van deze habitattypen zou echter (zeker voor de habitattypen 1130 en 1160 die op landschapsschaal zijn gedefinieerd) aanvullend gegevens moeten beoordelen over de verhoudingen van de verschillende deel-ecotopen, alsmede eventueel andere relevante indicatoren in deze ecosystemen. Dit dient nog ontwikkeld te worden, bij voorkeur op basis van regelmatig ingewonnen gegevens, zoals de ecotopenkarteringen van Rijkswaterstaat.

$\mathrm{Bij}$ het verbeteren van de beoordeling van Structuur \& Functie van mariene habitattypen kan ook worden bekeken in hoeverre monitoringsdata van mariene typische soorten gebruikt kan worden, zoals die nu door Stichting Anemoon worden verzameld in de Noordzee en de Oosterschelde.

\section{Kaderrichtlijn Water (KRW)}

Alle EKR-waarden van RWS en alle waterschappen zijn in principe te vinden op het waterkwaliteitsportaal (WKP; https://www.waterkwaliteitsportaal.nl). In de praktijk viel dit echter tegen en zijn de gegevens bij Rijkswaterstaat opgevraagd. Voor kleinere wateren (vennen) is geen informatie te vinden, omdat die buiten de KRW-rapportage vallen. Het zou voor de volgende rapportage goed zijn als de KRW-informatie die voor Natura 2000 nodig is eenvoudig, compleet en actueel op te vragen is of van een website te halen is. Deze methode is bruikbaar voor H3140 en $\mathrm{H} 3150$, en mogelijk voor het rivierendeel (subtype B) van H3260. Wel is een vraag bij de hier gerapporteerde methode of er geen andere weging moet plaatSvInden, namelijk op basis van de aanwezige oppervlakte van de habitattypen. Dit vereist echter een goed functionerende centrale database voor vegetatie- en habitatkaarten (zie §3.5).

Voor vennen (H3110, H3130, en H3160) is veel informatie voorhanden vanuit provincies op waterschappen, waar deze informatie is nogal versnipperd. Het zou goed zijn om ten behoeve van de Natura 2000-rapportage een aparte database op te bouwen, waarbij een beperkt aantal relevante indicatoren per ven in bepaalde periodes worden opgeslagen, zodat op basis van een groot aantal vennen landelijke analyses mogelijk worden van de structuur \& functie. Er moet dan tevens worden nagedacht over een maatlat, waarin de verschillende gegevens worden gewogen ten behoeve van een landelijke beoordeling. Deze informatie kan dan voor H3130 naast de NDFF-methode gebruikt worden. Voor beken (H3260A) kan op vergelijkbare wijze een database worden opgebouwd, die naast de NDFF-methode wordt gebruikt.

Voor de kwelders bestaat een goed functionerend monitoringsprogramma bij Rijkswaterstaat (VEGWAD), waarin wel de - relatief kleine oppervlakte - aan binnendijkse voorkomens ontbreken. De datastroom over deze gegevens zou beter georganiseerd moeten worden, waarbij analyses van de oppervlakte aan kwelderhabitattypen bij voorkeur elke zes jaar worden uitgevoerd, los van en voorafgaand aan de Natura 2000-rapportage.

\section{Nationale Database Flora en Fauna (NDFF)}

Enkele data-technische problemen met de NDFF-methode zijn voor de huidige rapportageperiode nog niet naar tevredenheid opgelost:

- criteria voor de selectie van km-hokken die in de relevante rapportageperiode(n) voldoende zijn geïnventariseerd en/of waarvoor is gecorrigeerd voor waarnemingsinspanning;

- de beoordeling van trends in soortensamenstelling op km-hokniveau.

Verder moet nog worden nagegaan hoe verspreidingsgegevens van karakteristieke fauna kunnen worden gebruikt (welke soorten? welk schaalniveau van beoordeling?). Ook is de eis dat er één gemeenschappelijk soort aanwezig moet zijn om een km-hok mee te nemen erg licht. Het zou beter 
zijn om met een statistisch model te gaan werken waarbij wordt gecorrigeerd voor waarnemersinspanning. Aan deze aspecten zal in nauw overleg met het CBS nog worden gewerkt.

Cruciaal voor de NDFF-methode is dat goed bekend is in welke km-hokken habitattype substantieel aanwezig is. De huidige verzameling van historische en actuele habitatkaarten moet hiertoe nog eenduidig worden beoordeeld (zie § 3.5).

Voor de huidige rapportage betekenen deze onzekerheden dat er terughoudend is gerapporteerd als de NDFF-methode een aanzienlijke verslechtering of verbetering te zien gaf ten opzichte van de voorgaande rapportage(s).

\section{Nederlandse Bosinventarisatie (NBI)}

De bosstatistieken kunnen goed worden gebruikt voor de beoordeling van voorraden en trends van dood hout voor de habitattypen H2180, H9110, H9120+H9190 en H9160B als onderdeel van de Art17-rapportage van S\&F. Gezien de verwantschap en landschappelijke samenhang van H9120 en $\mathrm{H} 9190$ is het aan te bevelen één beoordeling van dood hout uit te voeren voor beide typen gezamenlijk (zoals in Bijlage 8 onder 9120+9190 habkaart). De overige bosstypen (H9160A, H91D0, H91E0, H91F0) zijn niet representatief genoeg vertegenwoordigd in de meetpunten.

Het beschouwen van habitattypen op landschapsschaal (zoals uitgevoerd voor H2180 en $\mathrm{H} 9120+\mathrm{H} 9190$ ) heeft geen directe meerwaarde voor de rapportage maar geeft belangrijke informatie over een eventueel contrast in voorraden dood hout tussen de habitattypen en de sterker beheerde bossen elders in hetzelfde landschap.

\section{Netwerk Ecologische Monitoring (NEM)}

Relatief veel van de indicatoren die met de NEM-PQ's per habitattype zijn geanalyseerd geven geen duidelijke trend te zien, waarbij bedacht moet worden dat de 'onzekere' trends in feite 'stabiel' zijn (zie voetnoot in $\S 4.6 .2$ ). Bedacht moet worden dat er mogelijk veel variatie tussen trends in PQ's bestaat, die hier worden 'uitgemiddeld'. Mogelijk kunnen ook ander soort analyses worden uitgevoerd, en daarnaast zou het goed zijn om voor een select aantal habitattypen een aantal extra PQ's in deze analyse te betrekken. Meer PQ's betekenen dat in principe eerder significante veranderingen kunnen worden gesignaleerd. Die extra PQ's kunnen worden geselecteerd uit reeds bestaande meetnetten (waarmee ook historische data reeds voorhanden is) of aanvullende, nieuwe PQ's binnen het NEM meetnet. Tenslotte zou het goed zijn om de gebruikte indicatoren af te stemmen met PBL en provincies, zodat analyses bij die organisaties niet andere resultaten opleveren door het gebruik van verschillende indicatoren. Dit alles zijn verbeteringen die voor de volgende rapportage moeten worden doorgevoerd.

Een algemener punt is dat er enige twijfel bestaat over de bruikbaarheid van de data, aangezien PQ's in veel situaties (en in het algemeen) vooral successie laten zien, omdat de PQ's slechts bij uitzondering liggen op locaties waar ingrepen zijn gedaan. Het is echter de vraag in hoeverre deze aanname terecht is. Er tegenover staat namelijk een analyse van het CBS waaruit bleek dat in $41 \%$ van alle LMF-PQ's sprake was van enige mate van zichtbare verstoring in de vorm van diepe rijsporen, afplaggen, etc. Bovendien liggen volgens een maatregelenkaart van het PBL 1600 van de 10.000 PQ's in gebieden waar de provincies en terreinbeherende organisaties natuurherstel toepassen.

\section{Typische soorten}

De huidige lijst van typische soorten is in omvang en samenstelling onvoldoende geschikt voor de Artikel 17-rapportage (zie Bijlsma \& Janssen 2014) en de methode van beoordeling op grond van periodiek herziene Rode Lijst-status sluit onvoldoende aan op de rapportagecyclus. Het gebruik van een lijst van typische soorten naast een uitgebreidere lijst van karakteristieke soorten moet nader worden afgestemd. De toepassing van de door het CBS ontwikkelde Virtuele Rode Lijsten lijkt een goed alternatief voor het gebruik van formele Rode Lijsten (zie § 4.4.2), maar betreft alleen soortgroepen die goed worden gemonitord.

\section{Ecologische variatie}

Behoud van de ecologische variatie van habitattypen is een belangrijk doel dat wordt nagestreefd door de Habitatrichtlijn. Dit is een aspect dat specifiek op landelijke schaal gewaarborgd moet worden, en 
niet of veel minder speelt in de Natura 2000-gebieden. Het behouden/herstellen van de ecologische variatie speelt een rol bij de vaststelling van de gunstige referentiewaarden voor verspreidingsgebied en oppervlakte (zie Bijlsma et al. 2014). Het kan echter beter geëvalueerd worden bij de beoordeling van de structuur \& functie. Voor een deel gebeurt dit nu reeds, door analyses op het niveau van subtypen uit te voeren voor habitattypen waarvan de subtypen in verschillende fysisch-geografische regio's voorkomen (zie bijlage 6). Mogelijk kan echter - voor de volgende rapportage - ook een aanvullende, eenvoudige aanpak worden ontwikkeld om het behoud van de ecologische variatie te evalueren, bijvoorbeeld binnen de oppervlakte en het verspreidingsgebied van een habitattype. De uitkomsten van die evaluatie kunnen dan worden meegewogen bij de landelijke beoordeling van structuur \& functie.

\section{Overige verbeterpunten}

Voor 6 habitattypen (1140, 2310, 2320, 5130, 7150 en 91D0) geldt 'Insufficient or no data available' en voor 10 habitattypen $(1130,1160,1320,2110,2140,2150,2160,2170,6130$ en 7210) is de beoordeling van S\&F 'Based mainly on expert opinion with very limited data'. Het gaat hierbij om structuur- en soortenarme typen, vaak dominantietypen, waarvoor zowel S\&F in strikte zin als de beoordeling van typische soorten nog niet kunnen worden beoordeeld met de hierboven beschreven methoden (zie ook Bijlsma \& Janssen 2014). Voor deze habitattypen dienen eenvoudige maatlatten en monitoringsprotocollen te worden ontwikkeld, op basis van data die reeds met regelmaat wordt ingewonnen of eenvoudig nieuw in te winnen is. 



\section{$5 \quad$ Rapportage Toekomstperspectief}

\subsection{Format}

Het format vraagt het volgende te rapporteren (zie Bijlage 2):

1. toekomstperspectief voor de parameters verspreidingsgebied, oppervlakte en structuur \& functie (format 9.1a, b en c);

2. eventuele toelichtende informatie (format 9.2);

\subsection{Data en werkwijze}

De Reporting Guidelines (DG Environment 2018) geven een uitvoerige toelichting over de te volgen werkwijze van beoordeling, uitgaande van de gerapporteerde Staat van Instandhouding van de parameters en een inschatting (door de betreffende expert) van de doorwerking van bedreigingen ten opzichte van genomen maatregelen voor de komende 12 jaar.

\subsection{Resultaten \& Discussie}

In totaal is voor drie habitattypen het toekomstperspectief negatiever ingeschat dan puur op basis van de scores van verspreidingsgebied, oppervlakte en structuur \& functie. De argumentatie voor deze drie typen wordt hieronder gegeven.

\section{H1310 Zilte pionierbegroeiingen}

Voor dit habitattype is de voortgaande zeespiegelstijging een alsmaar toenemende bedreiging. Uit verschillende studies is gebleken dat in de pionierzone van de kwelders al bij relatief weinig stijging van de zeespiegel de opslibbing te gering is om toenemende erosie te kunnen compenseren (Van Wijnen \& Bakker 2001; Vader \& Kuiters 2018), zodat het habitattype in oppervlakte zal afnemen.

\section{H3150 Meren met krabbenscheer en fonteinkruiden}

Het toekomstperspectief voor dit habitattype wordt negatiever beoordeeld dan de overige aspecten, naar aanleiding van het verdwijnen van waterplanten in grote delen van Laag Nederland (zie §4.4.2), dit ondanks een verbetering van de waterkwaliteit. Dit is hoogst waarschijnlijk een gevolg van onder meer de sterke toename van exotische rivierkreeften (Roessink et al. 2010). De vrees bestaat dat in de komende jaren deze exoten zich ook in andere delen van ons land sterk zullen uitbreiden (Kop van Overijssel, Friesland) en ook daar een bedreiging gaan vormen voor het habitattype 3150 .

\section{H7220 Kalktufbronnen}

De kalktufbronnen behoren tot de meest vervuilde voorbeelden van dit type in Europa (De Mars et al. 2019). Omdat het intrekgebied van het water van de kalktufbronnen in veel gevallen op hogere plateaus is gelegen, duurt het lang voordat dit water de bronnen bereikt. De vrees is dan ook dat de watervervuiling in de komende jaren alleen maar erger zal worden, zolang er geen maatregelen genomen worden om de vervuiling met meststoffen in de inzijggebieden te stoppen. 



\section{Literatuur}

Bijlsma, R.J., G.J. van Dorland, D. Bal \& J.A.M. Janssen. 2010. Oude bossen en oude bosgroeiplaatsen. Een referentiebestand voor het karteren van de habitattypen Beukeneikenbossen met hulst en Oude eikenbossen. Alterra-rapport 1967, Wageningen.

Bijlsma, R.J. \& J.A.M. Janssen. 2014. Structuur en functie van habitattypen. Onderdeel van de documentatie van de Habitatrichtlijn artikel 17-rapportage 2013. WOt-technical report 33. Wettelijke Onderzoekstaken Natuur \& Milieu, Wageningen.

Bijlsma R.J., J.A.M. Janssen, E.J. Weeda \& J.H.J. Schaminée. 2014. Gunstige referentiewaarden voor oppervlakte en verspreidingsgebied van Natura 2000-habitattypen in Nederland. Wettelijke Onderzoekstaken Natuur \& Milieu, WOt-rapport 125, Wageningen.

Bijlsma, R.J., E. Agrillo, F. Attorre, L. Boitani, A. Brunner, P. Evans, R. Foppen, S. Gubbay, J.A.M. Janssen, A. van Kleunen, W. Langhout, R. Noordhuis, M. Pacifici, I. Ramirez, C. Rondinini, M. van Roomen, H. Siepel \& H.V. Winter. 2019a. Defining and applying the concept of Favourable Reference Values for species and habitats under the EU Birds and Habitats Directives: technical report. Wageningen Environmental Research report 2928, Wageningen.

Bijlsma, R.J., E. Agrillo, F. Attorre, L. Boitani, A. Brunner, P. Evans, R. Foppen, S. Gubbay, J.A.M. Janssen, A. van Kleunen, W. Langhout, M. Pacifici, I. Ramirez, C. Rondinini, M. van Roomen, H. Siepel, C.A.M. van Swaaij \& H.V. Winter. 2019b. Defining and applying the concept of Favourable Reference Values for species and habitats under the EU Birds and Habitats Directives : examples of setting favourable reference values. Wageningen Environmental Research report 2929, Wageningen.

Bos, O.G., E.M. Dijkman \& J. Cremer. 2008. Gegevens voor aanmelding van mariene Habitatrichtlijngebieden: Doggersbank, Klaverbank, Noordzeekustzone, Vlakte van de Raan. Rapport C081/08, Wageningen Imares, Texel.

Bos, O.G., S. Glorius J.W.P. Coolen, J. Cuperus, B. van der Weide, A. Aguera Garcia, P.W. van Leeuwen, W. Lengkeek, S. Bouma, M. Hoppe \& H. van Pelt. 2014. Natuurwaarden Borkumse Stenen. Project Aanvullende beschermde gebieden. Rapport C115.14, Imares, Texel.

Coops, H. 2016. MWTL meetnet water- en oeverplanten jaarrapportage 2016. Scirpus Ecologisch Advies.

DG Environment. 2017. Reporting under Article 17 of the Habitats Directive: Explanatory notes and guidelines for the period 2013-2018. Final version May 2017. Brussels. Pp 188

De Mars, H., G. van Dijk, B. van der Weijden, A. Grootjans \& F. Smolders. 2019. Nederlandse kalktufbronnen, de meest vervuilde bronnen van Europa. De Levende Natuur 120: 193-199.

De Vries, W., P. Bolhuis, A. van den Burg \& R. Bobbink. 2017. Doorgaande verzuring van bosbodems. Oorzaken en gevolgen voor het bosecosysteem. Vakblad Natuur Bos Landschap, September 2017: 32-35.

Dijkema K.S., D.J. de Jong, M.J. Vreeken-Buijs \& W.E. van Duin. 2005. Kwelders en schorren in de Kaderrichtlijn Water. Ontwikkeling van Potentiële Referenties en van Potentiële Goede Ecologische Toestanden. Rapport RIKZ/2005.020, Rijkswaterstaat, Middelburg/Delft.

Dirkse, G.M., W.P. Daamen, H. Schoonderwoerd, M. Japink, M. van Jole, R. van Moorsel, P. Schnitger W.J. Stouthamer \& M. Vocks. 2007. Meetnet Functievervulling bos 2001-2005. Vijfde Nederlandse Bosstatistiek. Directie Kennis, Ministerie van Landbouw, Natuur en Voedselkwaliteit. Rapport DK nr 2007/065. Ede.

EEA. 2012. Streamlining European biodiversity indicators 2020: Building a future on lessons learnt from the SEBI 2010 process. EEA Technical report 11/2012, Copenhagen.

Eurofins/Aquasense, Periplus Group \& Rijkswaterstaat WVL. 2018. Habitattypenkaart Klaverbank, versie 3.0 (datum: 19-01-2018). Halley, J.M., N. Monokrousos, A.D.Mazaris \& D. Vokou. 2017. Extinction debt in plant communities: where are we now? J.Veg.Sc. 28: 459-461.

Hommel, P., R.J. Bijlsma, H. Jansman, J. den Ouden, J. Schaminée, R. de Waal \& M. Wallis de Vries. 2018. Karakterisering, uitbreiding en herstel kwaliteit van Veldbies-Beukenbossen. OBN223-HE. VBNE, Driebergen. 
Janssen, J.A.M., E.J. Weeda, P.C. Schipper, R.J. Bijlsma, J.H.J. Schaminée, G.H.P. Arts, C.M. Deerenberg, O.G. Bos \& R.G. Jak. 2014. Habitattypen in Natura 2000-gebieden. Beoordeling van oppervlakte, representativiteit en behoudsstatus in de Standard Data Forms. WOt-technical report 8 , Wageningen.

Jentink, R. 2018. Ontwikkeling kweldervegetaties Waddengebied. Ontwikkeling kweldervegetaties in de verschillende KRW Waterlichamen periode 1998-2015. Rijkswaterstaat Centrale Informatievoorziening, Rotterdam.

Kleijn, D., R.J. Bink, C.J.F. ter Braak, R. van Grunsven, W.A. Ozinga, I. Roessink, J.A. Scheper, A.M. Schmidt, M.F. Wallis de Vries, R. Wegman, F.F. van der Zee \& Th. Zeegers. 2018. Achteruitgang insectenpopulaties in Nederland: trends, oorzaken en kennislacunes. WENR-rapport 2871, Wageningen.

Kranenbarg, J. \& F. Spikmans. 2013. Achtergronddocument Rode Lijst Vissen 2011. Zoetwatervissen. Stichting RAVON, Nijmegen.

Lindeboom, H., J. Geurts van Kessel \& L. Berkenbosch. 2005. Gebieden met bijzondere ecologische waarden op het Nederlands Continentaal Plat. Rapport RIKZ/2005.008, Alterra Rapport nr. 1109. Rijkswaterstaat, Den Haag / Alterra, Texel.

Mücher, S., H. Kramer, R. van der Wijngaart \& R. Huiskes. 2017. Ontwikkeling van een Remote Sensing monitoringssystematiek voor vegetatiestructuur. Pilotstudie: detectie verruiging Grijze Duinen (H2130) voor het Natura 2000-gebied Meijendel-Berkheide. Rapport 2838, Wageningen Environmental Research, Wageningen.

Müller, J. \& R. Bütler, 2010. A review of habitat thresholds for dead wood: a baseline for management recommendations in European forests. European Journal of Forest Research 129: 981-992.

Tolman, M.E. \& D.P. Pranger. 2014. Toelichting bij de Vegetatiekartering Slufter Voorne en de Kwade hoek 2012 : op basis van false colour luchtfoto's 1:5.000. EGG consult, Rijkswaterstaat Centrale Informatievoorziening, Delft.

Ramaekers, I. 2014. Oppervlakte-bepaling Kalktufbronnen (H7220). Natura 2000-gebieden Geuldal en Noorbeemden \& Hoogbos. Rapport Ecologica, in opdracht van Provincie Limburg \& Natuurmonumenten.

Reitsma, J.M. \& J. de Jong. 2015 Toelichting bij de vegetatiekartering Oosterschelde 2013 op basis van false colour-luchtfoto's 1:5000. Rapport Bureau Waardenburg, Culemborg.

Reitsma, J.M. \& J. de Jong. 2018 Toelichting bij de vegetatiekartering Westerschelde 2016 op basis van false colour-luchtfoto's 1:5000. Rapport Bureau Waardenburg, Culemborg.

Roessink, I., J. van Giels, A. Boerkamp \& F.G.W.A. Ottburg. 2010. Invloed van de invasieve rode Amerikaanse rivierkreeft (Procambarus clarkii) en de geknobbelde Amerikaanse rivierkreeft (Orconectes virilis) op waterplanten en waterkwaliteit. Rapport 2052, Alterra, Wageningen.

Sas, H., P. Kamermans, T. van der Have, W. Lengkeek \& A. Smaal. 2016. Shellfish reef restoration pilots: Voordelta, The Netherlands. Annual report. Pacific Oyster Consortion. Commissioned by ARK Natuurontwikkeling and WWF Netherlands.

Schaminée, J.H.J., M.G.H. Bongers, H.A.M.M. van Loon \& N.M. Rooijen (red). 2013. Wegwijs in de natuur: achtergronden, illustraties en toepassingen van het informatiesysteem SynBioSys. KNNV Uitgeverij, Zeist.

Schaminée, J.H.J., J.A.M. Janssen, R. Haveman, S.M. Hennekens, G.B.M. Heuvelink, H.P.J. Huiskes \& E.J. Weeda. 2006. Schatten voor de natuur - achtergronden, inventaris en toepassingen van de Landelijke Vegetatie Databank. KNNV Uitgeverij, Utrecht.

Schelhaas, M.J., A.P.P.M. Clerkx, W.P. Daamen, J.F. Oldenburger, G. Velema, P. Schnitger, H. Schoonderwoerd \& H. Kramer. 2014. Zesde Nederlandse Bosinventarisatie; Methoden en basisresultaten. Alterra rapport 2545, Wageningen.

STOWA 2016. Referenties en maatlatten voor natuurlijke watertypen voor de Kaderrichtlijn Water 2015-2021.

Tien, N., H. Heessen, J. Kranenbarg \& B. Trapman. 2016. Rode Lijst vissen 2011; Achtergronddocument Zoutwatervissen. IMARES rapport C021/16. IMARES Wageningen UR, Wageningen.

Vader, L. \& L. Kuiters (2018). Klimaatverandering en kwelders: verdrinken of verjongen? In: Schaminée, J.H.J. \& J.A.M. Janssen (red). Buigen of barsten. Beschouwingen over de veerkracht van de natuur. KNNV Uitgeverij, Zeist.

Van Dam, H., G.H.P. Arts, R. Bijkerk, H. Boonstra, J.D.M. Belgers \& A. Mertens. 2014. Natuurkwaliteit Drentse vennen gaat vooruit. De Levende Natuur 115(5): 215-221. 
Van Dam, H., D. Tempelman, E. Brouwer, K. Hanhart, F.J.H. van Erve, B.F. van Tooren \& A. Mertens. 2017. Een eeuw monitoring van vennen in Midden-Brabant. Basis voor adequaat beheer. Rapport AWN 1410, Amsterdam.

Van den Burg, A.B. \& J.J. Vogels. 2017. Zuur voor de fauna. Landschap 34(2): 70-79.

Van den Oever, E.A., E. Verduin \& R. van Lil. 2018. Memo beslisboom en habitattypenkaart Klaverbank. Memo Periplus Group.

Van de Riet, B. \& R. Bobbink 2018 (2018). Effectiviteit van herstelmaatregelen voor de zinkvegetatie: de middellange termijn. Monitoring OBN-16-HE. VBNE, Driebergen.

Van Dorland, G.J., R.J. Bijlsma, D. Bal \& J.A.M. Janssen. 2012. Een kaart van de oude bosgroeiplaatsen in Nederland. Basisbestand voor de bepaling van de landelijke verspreiding van de habitattypen Beuken-eikenbossen met hulst (H9120) en Oude eikenbossen (H9190). Alterrarapport 2376, Wageningen.

Van Kleunen, A., R. Foppen \& C. van Turnhout. 2017. Basisrapport voor de Rode Lijst Vogels 2016 volgens Nederlandse en IUCN-criteria. Rapport 2017/34, Sovon Vogelonderzoek Nederland, Nijmegen.

Van Moorsel, G.W.N.M. 2003. Ecologie van de Klaverbank. BiotaSurvey 2002, Ecosub, Doorn, 154 pp.

Van Swaay, C.A.M. 2019. Basisrapport Rode Lijst Dagvlinders 2019 volgens Nederlandse en IUCNcriteria. Rapport VS2019.001, De Vlinderstichting, Wageningen.

Van Tongeren, O., N. Gremmen \& S.M. Hennekens. 2006. Assignment of relevés to pre-defined classes by supervised clustering of plant communities using a new composite index. Journal of Vegetation Science 9: 525-536.

Van Wijnen, H.J. \& J.P. Bakker. 2001. Long-term surface elevation change in salt marsh s: a prediction of marsh response to future sea-level rise. Estuarine, Coastal and Shelf Sciences 52: 381-390.

Vlaams-Nederlandse Scheldecommissie. 2019. Systeemanalyse natuur Schelde-estuarium. Uitgave Vlaams-Nederlandse Scheldecommissie, Bergen op Zoom.

Vogels, J.J., W.C.E.P. Verberk, L.P.M. Lamers \& H. Siepel. 2017. Can changes in soil biochemistry and plant stoichiometry explain loss of animal diversity of heathlands? Biological Conservation 212, Part B: 432-447.

Wielakker, D., A. Bak \& J.M. Reitsma. 2011. Herziening referenties en doelen Kaderrichtlijn Water voor Zeegras en Kwelders in K2, O2 en M32 watertypen. Rapport 11-196, Bureau Waardenburg, Culemborg.

Wijdeven, S.M.J. 2005. Dood hout in het Nederlandse bos. In G.A.J.M. Jagers op Akkerhuis et al., Dood hout en biodiversiteit. Een literatuurstudie naar het voorkomen van dood hout in Nederlandse bossen en het belang ervan voor de duurzame instandhouding van geleedpotigen, paddenstoelen en mossen. Alterra-rapport 1320, Wageningen; hoofdstuk 2.

Wijnhoven, S. 2018. T0 beoordeling kwaliteitstoestand NCP op basis van de Benthische Indicator Soorten Index (BISI). Toestand en ontwikkelingen van benthische habitats en KRM-gebieden op de Noordzee in en voorafgaand aan 2015. Rapport 2018-01, Ecoauthor, Heinkenszand.

Wijnhoven, S. \& O. Bos. 2017 Benthische Indicator Soorten Index (BISI). Ontwikkelingsproces en beschrijving van de Nationale Benthos Indicator Noordzee inclusief protocol voor toepassing. Rapport Ecoauthor 2017-2, Heinkenszand.

Wijnhoven, S., G Duineveld., M. Lavaleye, J. Craeymeersch, K. Troost \& M. van Asch. 2013. Kaderrichtlijn Marien indicatoren Noordzee. Naar een uitgebalanceerde selectie van indicatorsoorten ter evaluatie van habitats en gebieden en scenario's hoe die te monitoren. Monitor Taskforce Publication Series 2013-02. NIOZ, Den Hoorn \& Yerseke, 105 pp. 



\section{Verantwoording}

WOt-technical report: 171

Projectnummer: WOT-04-009-034.04

Dit project werd begeleid door een commissie waarin de volgende personen deelnamen: Annemiek Adams (Ministerie LNV)

Rienk-Jan Bijlsma (WENR)

Gerdien Bos (De Vlinderstichting)

Sandra Clerkx (WENR)

John Janssen (WENR)

Ellen Meulman (BIJ12)

Marion Pross (Provincie Zeeland)

Wilmar Remmelts (Ministerie LNV)

Anne Schmidt (WENR)

Peter van der Molen (BIJ12)

André van Kleunen (SOVON)

Arco van Strien (CBS)

Suzanne Stuijfzand (Rijkswaterstaat)

Chris van Swaay (De Vlinderstichting)

Met als aanvullende agendaleden:

Frank Bos (Provincie Utrecht)

Meinte Engelmoer (Provincie Friesland)

Voorts zijn de eerste resultaten besproken in een drietal deskundigenbijeenkomsten met vertegenwoordigers van rijksoverheid, provincies en terreinbeheerders.

De rapportage per habitattype is door de volgende personen gedaan:

$\begin{array}{ll}1110 & \text { Sander Wijnhoven (Ecoauthor) } \\ 1130 & \text { Tom Ysebaert (WMR) } \\ 1140 & \text { Martin Baptist (WMR) } \\ 1160 & \text { Tom Ysebaert (WMR) } \\ 1170 & \text { Sander Wijnhoven (Ecoauthor) } \\ 1310 & \text { John Janssen (WENR) } \\ 1320 & \text { John Janssen (WENR) } \\ 1330 & \text { John Janssen (WENR) } \\ 2110 & \text { Bart de Knegt (WENR) } \\ 2120 & \text { Bart de Knegt (WENR) } \\ 2130 & \text { John Janssen (WENR) } \\ 2140 & \text { John Janssen (WENR) } \\ 2150 & \text { John Janssen (WENR) } \\ 2160 & \text { John Janssen (WENR) } \\ 2170 & \text { Joop Schaminée (WENR) } \\ 2180 & \text { Rienk-Jan Bijlsma (WENR) } \\ 2190 & \text { Joop Schaminée (WENR) } \\ 2310 & \text { Rienk-Jan Bijlsma (WENR) } \\ 2320 & \text { Rienk-Jan Bijlsma (WENR) } \\ 2330 & \text { Rienk-Jan Bijlsma (WENR) } \\ 3110 & \text { Gertie Arts (WENR) } \\ 3130 & \text { Gertie Arts (WENR) } \\ 3140 & \text { Gertie Arts (WENR) }\end{array}$


6110 Joop Schaminée (WENR)

6120 John Janssen (WENR)

6130 John Janssen (WENR)

6210 Joop Schaminée (WENR)

6230 Rienk-Jan Bijlsma (WENR)

6410 Joop Schaminée (WENR)

6430 Joop Schaminée (WENR)

6510 John Janssen (WENR)

7110 Bart de Knegt (WENR)

7120 Bart de Knegt (WENR)

7140 Bart de Knegt (WENR)

7150 Rienk-Jan Bijlsma (WENR)

7210 Bart de Knegt (WENR)

7220 John Janssen (WENR)

7230 Joop Schaminée (WENR)

9110 Rienk-Jan Bijlsma (WENR)

9120 Rienk-Jan Bijlsma (WENR)

9160 Rienk-Jan Bijlsma (WENR)

9190 Rienk-Jan Bijlsma (WENR)

91D0 Rienk-Jan Bijlsma (WENR)

91E0 Rienk-Jan Bijlsma (WENR)

91F0 Rienk-Jan Bijlsma (WENR)

Stephan Hennekens (WENR) verzorgde de verspreidingskaarten van habitattypen. Mart-Jan Schelhaas (WENR) heeft een belangrijke bijdrage geleverd aan de analyse van de NBI-data. De NEM-PQ's zijn geanalyseerd door Tom vn der Meij (CBS). De PQ-gegevens van Waternet zijn geanalyseerd door Franziska Hauch, met dank aan de dataleverantie door Bart Specken (Waternet).

De auteurs bedanken allen voor hun bijdrage aan het tot stand komen van deze rapportage.

Akkoord Referent/ Extern contactpersoon

functie: Beleidsmedewerker Kennis \& Systeem Natura 2000

naam: $\quad$ Annemiek Adams

datum: $\quad 20$ februari 2020

Akkoord Intern contactpersoon

naam: Anne Schmidt

datum: 9 februari 2020 


\section{Bijlage 1 Evaluatie-matrix voor beoordeling staat van instandhouding habitattypen}

\begin{tabular}{|c|c|c|c|c|}
\hline \multirow[t]{2}{*}{ Parameter } & \multicolumn{3}{|c|}{ Conservation Status } & \multirow[b]{2}{*}{$\begin{array}{c}\text { Unknown } \\
\text { (insufficient } \\
\text { information to make an } \\
\text { assessment) }\end{array}$} \\
\hline & $\begin{array}{c}\text { Favourable } \\
\text { ('green') }\end{array}$ & $\begin{array}{l}\text { Unfavourable - } \\
\text { Inadequate } \\
\text { ('amber') }\end{array}$ & $\begin{array}{c}\text { Unfavourable - Bad } \\
\text { ('red') }\end{array}$ & \\
\hline $\begin{array}{l}\text { Range } \\
\text { (within the } \\
\text { biogeographical/marine } \\
\text { region concerned) }\end{array}$ & $\begin{array}{l}\text { Stable (loss and expansion } \\
\text { in balance) or increasing } \\
\text { AND not smaller than the } \\
\text { 'favourable reference } \\
\text { range' }\end{array}$ & Any other combination & $\begin{array}{l}\text { Large decrease: Equivalent } \\
\text { to a loss of more than } 1 \% \\
\text { per year within period } \\
\text { specified by MS OR } \\
\text { More than } 10 \% \text { below } \\
\text { 'favourable reference } \\
\text { range' }\end{array}$ & $\begin{array}{l}\text { No or insufficient reliable } \\
\text { information available }\end{array}$ \\
\hline $\begin{array}{l}\text { Area covered by } \\
\text { habitat type } \\
\text { within range }^{6}\end{array}$ & $\begin{array}{l}\text { Stable (loss and expansion } \\
\text { in balance) or increasing } \\
\text { AND } \\
\text { not smaller than the } \\
\text { 'favourable reference area' } \\
\text { AND } \\
\text { without significant changes } \\
\text { in distribution pattern } \\
\text { within range (if data } \\
\text { available) }\end{array}$ & Any other combination & $\begin{array}{l}\text { Large decrease in surface } \\
\text { area: Equivalent to a loss of } \\
\text { more than } 1 \% \text { per year } \\
\text { (indicative value MS may } \\
\text { deviate from if duly } \\
\text { justified) within period } \\
\text { specified by MS OR With } \\
\text { major losses in distribution } \\
\text { pattern within range OR } \\
\text { More than } 10 \% \text { below } \\
\text { 'favourable reference area' }\end{array}$ & $\begin{array}{l}\text { No or insufficient reliable } \\
\text { information available }\end{array}$ \\
\hline $\begin{array}{l}\text { Specific structure } \\
\text { and functions } \\
\text { (including typical } \\
\text { species }^{7} \text { ) }\end{array}$ & $\begin{array}{l}\text { Structures and functions } \\
\text { (including typical species) } \\
\text { in good condition and no } \\
\text { significant deteriorations / } \\
\text { pressures }\end{array}$ & Any other combination & $\begin{array}{l}\text { More than } 25 \% \text { of the area } \\
\text { is unfavourable as regards } \\
\text { its specific structures and } \\
\text { functions (including typical } \\
\text { species) }\end{array}$ & $\begin{array}{l}\text { No or insufficient reliable } \\
\text { information available }\end{array}$ \\
\hline $\begin{array}{l}\text { Future } \\
\text { prospects } \\
\text { (as regards range, area } \\
\text { covered and specific } \\
\text { structures and functions) }\end{array}$ & $\begin{array}{l}\text { The habitats prospects for } \\
\text { its future are excellent / } \\
\text { good, no significant impact } \\
\text { from threats expected; } \\
\text { long-term viability assured }\end{array}$ & Any other combination & $\begin{array}{l}\text { The habitats prospects are } \\
\text { bad, severe impact from } \\
\text { threats expected; long- } \\
\text { term viability not assured. }\end{array}$ & $\begin{array}{l}\text { No or insufficient reliable } \\
\text { information available }\end{array}$ \\
\hline $\begin{array}{c}\text { Overall assessment of } \\
\text { CS }\end{array}$ & $\begin{array}{c}\text { All 'green' } \\
\text { OR } \\
\text { three 'green' and one } \\
\text { 'unknown' }\end{array}$ & $\begin{array}{l}\text { One or more 'amber' } \\
\text { but no 'red' }\end{array}$ & One or more 'red' & $\begin{array}{c}\text { Two or more 'unknown' } \\
\text { combined with green or } \\
\text { all 'unknown' }\end{array}$ \\
\hline
\end{tabular}

\footnotetext{
${ }^{6}$ There may be situations where the habitat area has decreased as a result of management measures to restore another Annex I habitat or habitat of an Annex II species. The habitat could still be considered to be at 'Favourable Conservation Status' but in such cases give details in the Complementary Information section ('Other relevant information') of Annex D ${ }^{7}$ See definition of typical species in the explanatory notes and guidelines

${ }^{8}$ E.g. by discontinuation of former management, or is under pressure from significant adverse influences, e.g. critical loads of pollution exceeded
} 



\section{Bijlage 2 Instructies voor invullers van het "reporting format" voor Annex I habitattypen}

Deze uitgebreide tabel geeft een blauwdruk van het rapportageformat dat vanuit Europa wordt voorgeschreven. Het is gebruikt als instructie voor de verschillende invullers. Voorbeelden zijn ingevuld met rood, toelichtende tekst is weergegeven in blauw.

\section{NATIONAL LEVEL}

\section{General information}

\begin{tabular}{|l|l|}
\hline 1.1 Member State & $\begin{array}{l}\text { Use two-digit code according to list in the Reference portal } \\
\text { NL }\end{array}$ \\
\hline \multirow{3}{*}{$\mathbf{1 . 2}$ Habitat code } & $\begin{array}{l}\text { Select code from habitat checklist in the Reference portal } \\
\text { (do not use subtypes) } \\
\text { Bijvoorbeeld: } 1310\end{array}$ \\
\hline
\end{tabular}

\section{Maps}

Distribution of the habitat type within the Member State concerned

\begin{tabular}{|c|c|}
\hline 2.1 Year or period & $\begin{array}{l}\text { Year or period when the distribution data was collected } \\
2007-2018 \\
\text { In principe wordt hier } 2007-2018 \text { ingevuld. Bij uitzondering wordt } \\
\text { hiervan afgeweken. }\end{array}$ \\
\hline 2.2 Distribution map & $\begin{array}{l}\text { Submit a map together with relevant metadata following the technical } \\
\text { specifications in the Explanatory Notes \& Guidelines. The standard for } \\
\text { habitat distribution is } 10 \times 10 \mathrm{~km} \text { ETRS grid cells, projection ETRS LAEA } \\
5210 \\
\text { Deze wordt in SynBioSys gemaakt, inclusief een opvulling van hokken } \\
\text { volgens de "opvultool". Echter: de berekeningen van } \\
\text { verspreidingsgebied (areaal) zijn gebaseerd op kaarten in RD- } \\
\text { coördinaten voor de terrestrische typen, zoals dat ook in de afgelopen } \\
\text { rapportages hebben gedaan Voor de mariene typen zijn de kaarten én } \\
\text { de berekeningen in ETRS coördinaten uitgevoerd. }\end{array}$ \\
\hline $\begin{array}{l}2.3 \text { Distribution map } \\
\text { Method used }\end{array}$ & $\begin{array}{l}\text { Select one of the following methods: } \\
\text { a) Complete survey or a statistically robust estimate } \\
\text { b) Based mainly on extrapolation from a limited amount of data } \\
\text { c) Based mainly on expert opinion with very limited data } \\
\text { d) Insufficient or no data available } \\
\text { a } \\
\text { Het zijn niet altijd kaarten die alle voorkomens } 100 \% \text { afdekken, maar } \\
\text { op schaal } 10 \times 10 \mathrm{~km} \text { hokken komt het wel in de buurt. }\end{array}$ \\
\hline 2.4 Additional maps & $\begin{array}{l}\text { MS can submit an additional map, deviating from standard submission } \\
\text { map under } 2.2 \text { and/or a range map } \\
\text { Niet invullen }\end{array}$ \\
\hline
\end{tabular}




\section{BIOGEOGRAPHICAL LEVEL}

Complete for each biogeographical region or marine region concerned

\section{Biogeographical and marine regions}

\begin{tabular}{|l|l|}
\hline $\begin{array}{l}\text { 3.1 Biogeographical or marine } \\
\text { region where the habitat } \\
\text { occurs }\end{array}$ & $\begin{array}{l}\text { Choose one of the following: } \\
\end{array}$ \\
& $\begin{array}{l}\text { Alpine, Atlantic, Black Sea, Boreal, Continental, Mediterranean, } \\
\text { Macaronesian, Pannonian, Steppic, Marine Atlantic, Marine } \\
\text { Mediterranean, Marine Black Sea, Marine Macaronesian and Marine } \\
\text { Baltic Sea } \\
\text { Atlantic of Marine Atlantic } \\
\text { Voor habitattypen } 1110 \text { en } 1140 \text { wordt alleen Marine Atlantic } \\
\text { gerapporteerd. }\end{array}$ \\
\hline \multirow{3}{3.2}{ Sources of information } & $\begin{array}{l}\text { For data reported in the sections below provide relevant available } \\
\text { bibliographic references and/or link to Internet site(s) } \\
\text { Hier komt een verwijzing naar het technische WOt-achtergrondrapport. }\end{array}$ \\
&
\end{tabular}

\section{Range}

Range within the biogeographical/marine region concerned

\begin{tabular}{|c|c|c|}
\hline 4.1 Surface area & \multicolumn{2}{|c|}{$\begin{array}{l}\text { Total surface area of the range within biogeographical/marine region } \\
\text { concerned in } \mathrm{km}^{2} \\
\text { Bij } 1310: 5900 \\
\text { Dit is het aantal } 10 \times 10 \mathrm{~km} \text {-hokken } \times 100 \mathrm{~km}^{2}\end{array}$} \\
\hline $\begin{array}{l}\text { 4.2 Short-term trend } \\
\text { Period }\end{array}$ & \multicolumn{2}{|c|}{$\begin{array}{l}2007-2018 \text { (rolling 12-year time window) or period as close as possible } \\
\text { to that. The short-term trend should be used for the assessment of } \\
\text { range } \\
2001-2018\end{array}$} \\
\hline $\begin{array}{l}\text { 4.3 Short-term trend } \\
\text { Direction }\end{array}$ & \multicolumn{2}{|c|}{$\begin{array}{l}0=\text { stable / + = increasing / - = decreasing / } u=\text { uncertain } / x=\text { unknown } \\
\text { Bij 1310: } 0 \\
\text { Hier wordt een } 10 \% \text { marge ten opzichte van de vorige periode } \\
\text { gehanteerd, waarbij het verspreidingsgebied in de vorige periode zo } \\
\text { nodig eerst is gecorrigeerd. }\end{array}$} \\
\hline \multirow[t]{2}{*}{$\begin{array}{l}\text { 4.4 Short-term trend } \\
\text { Magnitude }\end{array}$} & a) Minimum & $\begin{array}{l}\text { Percentage change over the period indicated in } \\
\text { the field } 4.2 \text {. If a precise value is known provide } \\
\text { the same value under both minimum and } \\
\text { maximum } \\
\text { Bij een trend beneden de } 10 \% \text { hier invullen: } 0\end{array}$ \\
\hline & b) Maximum & $\begin{array}{l}\text { Percentage change over the period indicated in } \\
\text { the field } 4.2 \text {. If a precise value is known provide } \\
\text { the same value under both minimum and } \\
\text { maximum } \\
\text { Niet invullen }\end{array}$ \\
\hline $\begin{array}{l}4.5 \text { Short-term trend } \\
\text { Method used }\end{array}$ & \multicolumn{2}{|c|}{$\begin{array}{l}\text { Select one of the following methods: } \\
\text { a) Complete survey or a statistically robust estimate } \\
\text { b) Based mainly on extrapolation from a limited amount of data } \\
\text { c) Based mainly on expert opinion with very limited data } \\
\text { d) Insufficient or no data available } \\
\text { In principe kies je hier voor a) of b) }\end{array}$} \\
\hline
\end{tabular}




\begin{tabular}{|c|c|c|c|}
\hline $\begin{array}{l}\text { 4.6 Long-term trend } \\
\begin{array}{l}\text { Period } \\
\text { Optional }\end{array}\end{array}$ & \multicolumn{3}{|c|}{$\begin{array}{l}\text { A trend calculated over } 24 \text { years (1994-2018) } \\
\text { Niet invullen }\end{array}$} \\
\hline $\begin{array}{l}\text { 4.7 Long-term trend } \\
\begin{array}{l}\text { Direction } \\
\text { Optional }\end{array}\end{array}$ & \multicolumn{3}{|c|}{$\begin{array}{l}0=\text { stable } /+=\text { increasing } /-=\text { decreasing } / u=\text { uncertain } / x= \\
\text { unknown } \\
\text { Niet invullen }\end{array}$} \\
\hline \multirow[t]{2}{*}{$\begin{array}{l}4.8 \text { Long-term trend } \\
\text { Magnitude }\end{array}$} & a) Minimum & \multicolumn{2}{|c|}{$\begin{array}{l}\text { Percentage change over the period indicated in } \\
\text { the field } 4.6 . \text { If a precise value is known provide } \\
\text { the same value under both minimum and } \\
\text { maximum } \\
\text { Niet invullen }\end{array}$} \\
\hline & b) Maximum & \multicolumn{2}{|c|}{$\begin{array}{l}\text { Percentage change over the period indicated in } \\
\text { the field } 4.6 . \text { If a precise value is known provide } \\
\text { the same value under both minimum and } \\
\text { maximum } \\
\text { Niet invullen }\end{array}$} \\
\hline $\begin{array}{l}\text { 4.9 Long-term trend } \\
\text { Method used }\end{array}$ & \multicolumn{3}{|c|}{$\begin{array}{l}\text { Select one of the following methods: } \\
\text { a) Complete survey or a statistically robust estimate } \\
\text { b) Based mainly on extrapolation from a limited amount of data } \\
\text { c) Based mainly on expert opinion with very limited data } \\
\text { d) Insufficient or no data available } \\
\text { Niet invullen }\end{array}$} \\
\hline \multirow[t]{4}{*}{$\begin{array}{l}\text { 4.10 Favourable reference } \\
\text { range }\end{array}$} & \multicolumn{3}{|c|}{$\begin{array}{l}\text { a) In } \mathrm{km}^{2} \text { or } \\
\text { Bij voorkeur invullen in } \mathrm{km}^{2} \text {. Gebruik hiervoor de waarden uit het } \\
\text { rapport Bijlsma et al. (2014). Gunstige referentiewaarden.doc. Je moet } \\
\text { de FRR waarde nemen in de tabel op pagina } 26 / 27 \text { (derde kolom van } \\
\text { achteren). }\end{array}$} \\
\hline & \multicolumn{3}{|c|}{ b) Indicate if operators were used (using symbols $\approx,>,>>$ ) or } \\
\hline & \multicolumn{3}{|c|}{ c) If favourable reference range is unknown, indicate by using ' $x$ ' } \\
\hline & \multicolumn{3}{|c|}{$\begin{array}{l}\text { d) Indicate method used to set reference value if other than operators } \\
\text { Free text } \\
\text { Verwijzing naar Bijlsma et al. } 2014 \text { opnemen. Eventuele aanpassingen } \\
\text { van deze waarden bij a) worden hier toegelicht. }\end{array}$} \\
\hline \multirow[t]{5}{*}{$\begin{array}{l}\text { 4.11 Change and reason for } \\
\text { change in surface area of } \\
\text { range }\end{array}$} & \multicolumn{3}{|c|}{$\begin{array}{l}\text { Is there a change between reporting periods? } \\
\text { In het digitale format staat de vraag net andersom. Kies NO als er een } \\
\text { andere waarde wordt gerapporteerd, ook als er geen reële trend is. Als } \\
\text { dezelfde waarde als vorige keer wordt YES gerapporteerd. } \\
\text { If yes, provide the nature of that change. More than one option (a to d) can be } \\
\text { chosen } \\
\text { Als er sprake is van een daadwerkelijke verandering bij de vorige vraag, geef } \\
\text { dan hier aan wat de reden(en) van de verandering zijn. }\end{array}$} \\
\hline & \multicolumn{2}{|c|}{ a) yes, due to genuine change } & YES/NO \\
\hline & \multicolumn{2}{|c|}{ b) yes, due to improved knowledge/more accurate data } & YES/NO \\
\hline & \multicolumn{2}{|c|}{ c) yes, due to the use of different method } & YES/NO \\
\hline & \multicolumn{2}{|c|}{$\begin{array}{l}\text { d) yes, but there is no information on the nature of } \\
\text { change }\end{array}$} & YES/NO \\
\hline
\end{tabular}




\begin{tabular}{|l|l|}
\hline \multirow{5}{*}{ Optional } & $\begin{array}{l}\text { The change is mainly due to (select one of the reasons above): } \\
\text { genuine change / improved knowledge or more accurate data / the use } \\
\text { of a different method } \\
\text { Bij NO, deze altijd invullen, ook als er maar één reden is. }\end{array}$ \\
& $\begin{array}{l}\text { Other relevant information, complementary to the data requested under } \\
\text { fields } 4.1-4.11 \\
\text { De volgende standaard tekst overnemen voor terrestrische en } \\
\text { zoetwater typen, en waar nodig anpassen: }\end{array}$ \\
& $\begin{array}{l}\text { Distribution map is based on vegetation maps within Natura } 2000 \text {-sites and } \\
\text { relevé data in- and outside Natura } 2000 \text {-sites over a period of } 12 \text { years. Some } \\
\text { vegetation maps still contain uncertainties and relevé data may have gaps, but } \\
\text { we assume that total distribution is well covered for 90\% or more. A change of } \\
10 \% \text { is used as a Range data and trends are based upon maps in Dutch } \\
\text { Rijksdroehoek co-ordinates, while distribution maps have been delivered in } \\
\text { ETRS co-ordinates. threshold for positive or negative trends. Favourable } \\
\text { Reference Values are based on Bijlsma et al. (2014), WOt report } 125 . \text { Range } \\
\text { data and trends are based upon maps in Dutch Rijksdroehoek co-ordinates, } \\
\text { while distribution maps have been delivered in ETRS co-ordinates. } \\
\text { Voor mariene typen: } \\
\text { Distribution map is based on habitat maps of the coastal regions. For } \\
\text { the marine habitats } 1110 \text { to } 1170 \text { both the delivered maps and reported } \\
\text { range are based upon data in ETRS co-ordinates. }\end{array}$ \\
\hline
\end{tabular}

\section{Area covered by habitat}

Area covered by the habitat type within the range in the biogeographical/marine region concerned

\begin{tabular}{|c|c|c|}
\hline 5.1 Year or period & \multicolumn{2}{|c|}{$\begin{array}{l}\text { Year or period when data for surface area was recorded } \\
\text { Bij terrestrische en zoetwater typen: 2001-2012 } \\
\text { Bij mariene typen: 2013-2018 }\end{array}$} \\
\hline \multirow[t]{3}{*}{$\begin{array}{l}\text { 5.2 Surface area } \\
\left(\text { in } \mathrm{km}^{2}\right)\end{array}$} & a) Minimum & $\begin{array}{l}\text { Provide either interval ( } a \text { and } b \text { ) and/or best single } \\
\text { value (c) } \\
\text { niet invullen }\end{array}$ \\
\hline & b) Maximum & $\begin{array}{l}\text { Provide either interval ( } a \text { and } b \text { ) and/or best single } \\
\text { value (c) } \\
\text { niet invullen }\end{array}$ \\
\hline & $\begin{array}{l}\text { c) Best single } \\
\text { value }\end{array}$ & $\begin{array}{l}\text { Provide either interval ( } a \text { and } b \text { ) and/or best single } \\
\text { value (c) } \\
\text { In principe wordt hier de oppervlakte van de } \\
\text { vorige rapportage overgenomen, tenzij er (bij } \\
\text { uitzondering) betrouwbare, recente en complete } \\
\text { oppervlakte data voorhanden is. }\end{array}$ \\
\hline 5.3 Type of estimate & \multicolumn{2}{|c|}{$\begin{array}{l}\text { Best estimate / 95\% confidence interval / minimum } \\
\text { Best estimate }\end{array}$} \\
\hline
\end{tabular}




\begin{tabular}{|c|c|c|}
\hline $\begin{array}{l}5.4 \text { Surface area } \\
\text { Method used }\end{array}$ & \multicolumn{2}{|c|}{$\begin{array}{l}\text { Select one of the following methods: } \\
\text { a) Complete survey or a statistically robust estimate } \\
\text { b) Based mainly on extrapolation from a limited amount of data } \\
\text { c) Based mainly on expert opinion with very limited data } \\
\text { d) Insufficient or no data available } \\
\text { Bij de meeste typen kan a) worden ingevuld. Echter, voor typen die } \\
\text { relatief veel buiten N2000 voorkomen kan beter b) worden ingevuld. }\end{array}$} \\
\hline $\begin{array}{l}\text { 5.5 Short-term trend } \\
\text { Period }\end{array}$ & \multicolumn{2}{|c|}{$\begin{array}{l}2007-2018 \text { (rolling } 12 \text {-year time window) or period as close as possible } \\
\text { to it. The short-term trend should be used for the assessment of area } \\
\text { covered by habitat type } \\
2007-2018\end{array}$} \\
\hline $\begin{array}{l}\text { 5.6 Short-term trend } \\
\text { Direction }\end{array}$ & \multicolumn{2}{|c|}{$\begin{array}{l}0=\text { stable / + = increasing / - = decreasing / } u=\text { uncertain } \text { x }= \\
\text { unknown } \\
\text { Hierbij wordt in principe } 0 \text { (stabiel) ingevuld, tenzij er goede gegevens } \\
\text { zijn over de trend in de afgelopen periode. Die informatie hoeft niet per } \\
\text { se compleet te zijn, maar wel representatief voor het habitattype. In dat } \\
\text { geval onderbouwen bij } 5.15 \text { en bij } 5.7 \text { een globale grootte van de trend } \\
\text { aangeven. Hier wordt dus niet het verschil met de vorige rapportage } \\
\text { beoordeeld, maar een daadwerkelijke verandering in oppervlakte die is } \\
\text { opgetreden. }\end{array}$} \\
\hline \multirow[t]{3}{*}{$\begin{array}{l}5.7 \text { Short-term trend } \\
\text { Magnitude }\end{array}$} & a) Minimum & $\begin{array}{l}\text { Percentage change over the period indicated } \\
\text { in the field 5.5. If a precise value is known } \\
\text { provide the same value under both minimum } \\
\text { and maximum } \\
\text { Eventueel invullen indien trend NIET stabiel is }\end{array}$ \\
\hline & b) Maximum & $\begin{array}{l}\text { Percentage change over the period indicated } \\
\text { in the field 5.5. If a precise value is known } \\
\text { provide the same value under both minimum } \\
\text { and maximum } \\
\text { Eventueel invullen indien trend NIET stabiel is }\end{array}$ \\
\hline & $\begin{array}{l}\text { c) Confidence } \\
\text { interval }\end{array}$ & $\begin{array}{l}\text { Indicate confidence interval if a statistically } \\
\text { reliable method is used } \\
\text { Niet invullen }\end{array}$ \\
\hline $\begin{array}{l}5.8 \text { Short-term trend } \\
\text { Method used }\end{array}$ & \multicolumn{2}{|c|}{$\begin{array}{l}\text { Select one of the following methods: } \\
\text { a) Complete survey or a statistically robust estimate } \\
\text { b) Based mainly on extrapolation from a limited amount of data } \\
\text { c) Based mainly on expert opinion with very limited data } \\
\text { d) Insufficient or no data available } \\
\text { Indien er een trend is aangegeven, meestal: c) } \\
\text { Bij uitzondering: a) of b) } \\
\text { Indien trend stabiel is, waarschijnlijk: d) }\end{array}$} \\
\hline $\begin{array}{l}5.9 \text { Long-term trend } \\
\text { Period }\end{array}$ & \multicolumn{2}{|c|}{$\begin{array}{l}\text { A trend calculated over } 24 \text { years (1994-2018) } \\
\text { Niet invullen }\end{array}$} \\
\hline $\begin{array}{l}\text { 5.10 Long-term trend } \\
\text { Direction } \\
\qquad \text { Optional }\end{array}$ & \multicolumn{2}{|c|}{$\begin{array}{l}0=\text { stable } /+=\text { increasing } /-=\text { decreasing } / u=\text { uncertain } / x= \\
\text { unknown } \\
\text { Niet invullen }\end{array}$} \\
\hline $\begin{array}{l}5.11 \text { Long-term trend } \\
\text { Magnitude }\end{array}$ & a) Minimum & $\begin{array}{l}\text { Percentage change over the period indicated } \\
\text { in field 5.9. If a precise value is known } \\
\text { provide the same value under both minimum } \\
\text { and maximum } \\
\text { Niet invullen }\end{array}$ \\
\hline
\end{tabular}




\begin{tabular}{|c|c|c|c|}
\hline \multirow{2}{*}{ Optional } & b) Maximum & \multicolumn{2}{|c|}{$\begin{array}{l}\text { Percentage change over the period indicated } \\
\text { in field 5.9. If a precise value is known } \\
\text { provide the same value under both minimum } \\
\text { and maximum } \\
\text { Niet invullen }\end{array}$} \\
\hline & $\begin{array}{l}\text { c) Confidence } \\
\text { interval }\end{array}$ & \multicolumn{2}{|c|}{$\begin{array}{l}\text { Indicate confidence interval if a statistically } \\
\text { reliable method is used } \\
\text { Niet invullen }\end{array}$} \\
\hline $\begin{array}{l}5.12 \text { Long-term trend } \\
\text { Method used }\end{array}$ & \multicolumn{3}{|c|}{$\begin{array}{l}\text { Select one of the following methods: } \\
\text { a) Complete survey or a statistically robust estimate } \\
\text { b) Based mainly on extrapolation from a limited amount of data } \\
\text { c) Based mainly on expert opinion with very limited data } \\
\text { d) Insufficient or no data available } \\
\text { Niet invullen }\end{array}$} \\
\hline \multirow[t]{4}{*}{$\begin{array}{l}5.13 \text { Favourable reference } \\
\text { area }\end{array}$} & \multicolumn{3}{|c|}{$\begin{array}{l}\text { a) In } \mathrm{km}^{2} \text { or } \\
\text { Deze invullen uit rapport Bijlsma at al. 2014, tabel } 3.1 \text { (pg 20), tenzij er } \\
\text { reden is om hiervan af te wijken. }\end{array}$} \\
\hline & \multicolumn{3}{|c|}{$\begin{array}{l}\text { b) Indicate if operators were used }\left(\approx,>,>>,<^{9}\right) \text { or } \\
\text { Deze zo nodig invullen, zie Bijlsma at al. } 2014 \text {, tabel } 3.1 \text { (pg 20). }\end{array}$} \\
\hline & \multicolumn{3}{|c|}{ c) If favourable reference area is unknown indicate by using ' $x$ ' } \\
\hline & \multicolumn{3}{|c|}{$\begin{array}{l}\text { d) Indicate method used to set reference value if other than operators } \\
\text { Free text } \\
\text { Standaard tekst: } \\
\text { For FRV values see Bijlsma et al. } 2014\end{array}$} \\
\hline \multirow[t]{6}{*}{$\begin{array}{l}5.14 \text { Change and reason for } \\
\text { change in surface area }\end{array}$} & \multicolumn{3}{|c|}{$\begin{array}{l}\text { Is there a change between reporting periods? YES/NO } \\
\text { In het digitale format staat de vraag net andersom. Kies NO als er een } \\
\text { andere waarde wordt gerapporteerd, ook als er geen reële trend is. Als } \\
\text { dezelfde waarde als vorige keer wordt YES gerapporteerd. }\end{array}$} \\
\hline & \multicolumn{2}{|c|}{ a) yes, due to genuine change } & YES/NO \\
\hline & \multicolumn{2}{|c|}{ b) yes, due to improved knowledge/more accurate data } & YES/NO \\
\hline & \multicolumn{2}{|c|}{ c) yes, due to the use of different method } & YES/NO \\
\hline & \multicolumn{2}{|c|}{$\begin{array}{l}\text { d) yes, but there is no information on the nature of } \\
\text { change }\end{array}$} & YES/NO \\
\hline & \multicolumn{3}{|c|}{$\begin{array}{l}\text { The change is mainly due to (select one of the reasons above): } \\
\text { genuine change / improved knowledge or more accurate data / the use } \\
\text { of a different method } \\
\text { Bij NO, deze altijd invullen, ook als er maar één reden is. }\end{array}$} \\
\hline $\begin{array}{l}\text { 5.15 Additional information } \\
\qquad \text { Optional }\end{array}$ & \multicolumn{3}{|c|}{$\begin{array}{l}\text { Other relevant information, complementary to the data requested under } \\
\text { fields } 5.1-5.14 \\
\text { Free text } \\
\text { Standaard tekst: No reliable new data on area available }\end{array}$} \\
\hline
\end{tabular}

\footnotetext{
${ }^{9}$ Symbol ' $<$ ' can be used only in special cases like for the habitat type Degraded raised bog still capable of natural regeneration (7120); additional information in the Guidelines
} 


\section{Structure and functions}

\begin{tabular}{|c|c|c|c|}
\hline \multirow[t]{6}{*}{ 6.1 Condition of habitat } & \multirow[t]{2}{*}{$\begin{array}{l}\text { a) Area in good } \\
\text { condition }\end{array}$} & Minimum & $\begin{array}{l}\text { In } \mathrm{km}^{2} \\
\text { Area good }\end{array}$ \\
\hline & & Maximum & $\begin{array}{l}\text { In } \mathrm{km}^{2} \\
\text { Area good + "matig" }\end{array}$ \\
\hline & \multirow[t]{2}{*}{$\begin{array}{l}\text { b) Area in not- } \\
\text { good condition }\end{array}$} & Minimum & $\begin{array}{l}\text { In } k m^{2} \\
\text { Area not-good }\end{array}$ \\
\hline & & Maximum & $\begin{array}{l}\text { In } \mathrm{km}^{2} \\
\text { Area not-good + "matig" }\end{array}$ \\
\hline & \multirow{2}{*}{$\begin{array}{l}\text { c) Area where } \\
\text { condition is not } \\
\text { known }\end{array}$} & Minimum & $\begin{array}{l}\text { In } \mathrm{km}^{2} \\
\text { Area unknown }\end{array}$ \\
\hline & & Maximum & $\begin{array}{l}\text { In } \mathrm{km}^{2} \\
\text { Area unknown }\end{array}$ \\
\hline $\begin{array}{l}6.2 \text { Condition of habitat } \\
\text { Method used }\end{array}$ & \multicolumn{3}{|c|}{$\begin{array}{l}\text { Select one of the following methods: } \\
\text { a) Complete survey or a statistically robust estimate } \\
\text { b) Based mainly on extrapolation from a limited amount of data } \\
\text { c) Based mainly on expert opinion with very limited data } \\
\text { d) Insufficient or no data available } \\
\text { I. NDFF: b) } \\
\text { II. KRW /KRM: b) } \\
\text { III. expert-kennis: c) of d) }\end{array}$} \\
\hline $\begin{array}{l}\text { 6.3 Short-term trend of habitat } \\
\text { area in good condition } \\
\text { Period }\end{array}$ & \multicolumn{3}{|c|}{$\begin{array}{l}\text { 2007-2018 (rolling 12-year time window) or period as close as possible } \\
\text { to it. The short-term trend is to be used for the assessment of structure } \\
\text { and functions } \\
\quad \text { NDFF-methode: } 1999-2016 \\
\text { KRW /KRM-methode: } 2014-2016 \text { (in ieder geval voor KRW-data) } \\
\text { expert-kennis: } 2007-2018 \\
\text { NBI-methode: } 2005-2016 \\
\text { Uiteraard kun je hiervan afwijken als er andere gegevens zijn gebruikt. }\end{array}$} \\
\hline $\begin{array}{l}\text { 6.4 Short-term trend of habitat } \\
\text { area in good condition } \\
\text { Direction }\end{array}$ & \multicolumn{3}{|c|}{$\begin{array}{l}0=\text { stable / }+=\text { increasing } /-=\text { decreasing / } u=\text { uncertain } / x= \\
\text { unknown } \\
\text { Afhankelijk van methode en beschikbaarheid gegevens dit invullen. Bij } \\
\text { twijfel of onzekere informatie wordt } 0 \text { (stabiel) ingevuld. Bij } \\
\text { tegenstrijdige trends kun je voor } \mathrm{X} \text { kiezen. }\end{array}$} \\
\hline $\begin{array}{l}\text { 6.5 Short-term trend of habitat } \\
\text { area in good condition } \\
\text { Method used }\end{array}$ & \multicolumn{3}{|c|}{$\begin{array}{l}\text { Select one of the following methods: } \\
\text { a) Complete survey or a statistically robust estimate } \\
\text { b) Based mainly on extrapolation from a limited amount of data } \\
\text { c) Based mainly on expert opinion with very limited data } \\
\text { d) Insufficient or no data available } \\
\text { In principe zelfde als bij 6.2, maar het zou kunnen afwijken. }\end{array}$} \\
\hline 6.6 Typical species & \multicolumn{3}{|c|}{$\begin{array}{l}\text { Has the list of typical species changed in comparison to the previous } \\
\text { reporting period? YES/NO } \\
\text { If yes, provide the updated list as an additional spreadsheet and fill } \\
\text { field } 6.7 \\
\text { In principe is er geen nieuwe lijst, dus NO. Uitzondering vormen } \\
\text { habitattypen } 1110,1130 \text { en } 1170 .\end{array}$} \\
\hline
\end{tabular}




\begin{tabular}{|c|c|}
\hline $\begin{array}{l}\text { 6.7 Typical species } \\
\text { Method used }\end{array}$ & $\begin{array}{l}\text { If the list or the methodology has changed, describe method(s) used to } \\
\text { assess the status of typical species as part of the overall assessment of } \\
\text { structure and functions } \\
\text { Alleen invullen als er voldoende typische soorten zijn. Dan wordt hier de } \\
\text { TS-score gegeven, met een standaard zin erachter. Bijvoorbeeld: TS = } \\
\text { U1, analysis based on national Red Lists, corrected for recent trends } \\
\text { (calculations by CBS). } \\
\text { Als er te weinig typische soorten voor een beoordeling zijn: Not used; } \\
\text { number of TS is too low }\end{array}$ \\
\hline 6.8 Additional information & $\begin{array}{l}\text { Other relevant information, complementary to the data requested under } \\
\text { fields } 6.1-6.7 \\
\text { Free text } \\
\text { NDFF-methode: S\&F assessment based on NDFF analysis, in co- } \\
\text { operation with CBS } \\
\text { Bij soortenarme typen, waar } 100 \% \text { unknown is ingevuld bij 6.1: There } \\
\text { is no data on area with good S\&F available. There is no method for } \\
\text { assessing S\&F for this habitat type yet. } \\
\text { Bij andere methoden hiervan afwijken. } \\
\text { Hier ook aangeven of er een positieve trend is in S\&F, en welke } \\
\text { bronnen daarvoor gebruikt zijn. }\end{array}$ \\
\hline
\end{tabular}

\section{Main pressures and threats}

Dit wordt al voor je ingevuld op basis van de pressures and threats van de vorige rapportage, die op een standaard manier zijn omgezet naar de nieuwe codes en begrippen. Indien je dit voorstel wilt corrigeren (op basis van expert kennis), kun je dat bij 7.3 onderbouwen. Een verschil met de rapportage van zes jaar geleden is dat alleen prioriteiten Hoog en Middel worden aangegeven, dus pressures and threats met prioriteit Laag worden niet ingevuld. Zet de belangrijkste drukfactoren en bedreigingen $(\mathrm{H})$ altijd bovenaan in het rijtje.

\subsection{Characterisation of pressures/threats}

\begin{tabular}{|c|c|c|}
\hline \multirow[t]{2}{*}{ a) Pressure/threat } & \multicolumn{2}{|c|}{$\begin{array}{l}\text { b) Ranking of pressure/threat } \\
\text { Indicate whether the pressure/threat is of: } \\
H=\text { high importance (maximum } 5 \text { entries for pressures and } 5 \text { for threats) } \\
M=\text { medium importance }\end{array}$} \\
\hline & Pressure & Threat \\
\hline $\begin{array}{l}\text { List a maximum of } 10 \text { pressures } \\
\text { and a maximum of } 10 \text { threats } \\
\text { using code list provided on the } \\
\text { Reference portal }\end{array}$ & $\begin{array}{l}\text { Er is al een voorstel gedaan voor } \\
\text { deze lijst, zie toelichting boven. } \\
\text { Vul alleen de codes in, met tussen } \\
\text { haakjes de ranking, bijvoorbeeld: } \\
\text { D03.02 (H) } \\
\text { E03 (M) }\end{array}$ & $\begin{array}{l}\text { Er is al een voorstel gedaan voor } \\
\text { deze lijst, zie toelichting boven } \\
\text { Vul alleen de codes in met tussen } \\
\text { haakjes de ranking. }\end{array}$ \\
\hline $\begin{array}{l}\text { 7.2 Sources of information } \\
\text { Optional }\end{array}$ & \multicolumn{2}{|c|}{$\begin{array}{l}\text { If available, provide sources of information (URL, metadata) supporting } \\
\text { evidence of pressures reported as 'High' } \\
\text { Standaard tekst:"Previous report, workshop with experts from } \\
\text { provinces, and expert knowledge" } \\
\text { Je mag dit veld ook leeg laten. }\end{array}$} \\
\hline 7.3 Additional information & \multicolumn{2}{|c|}{$\begin{array}{l}\text { Other relevant information, complementary to the data requested under } \\
\text { field } 7.1 \\
\text { Free text } \\
\text { Hier alleen iets invullen als je afwijkt van het voorstel. Geef ook een } \\
\text { motivatie. }\end{array}$} \\
\hline
\end{tabular}




\section{Conservation measures}

\begin{tabular}{|c|c|}
\hline 1 Status of measures & $\begin{array}{l}\text { Are measures needed? (YES/NO) } \\
\text { If yes, indicate the status of measures: } \\
\text { a) Measures identified, but none yet taken or } \\
\text { b) Measures identified and taken or } \\
\text { c) Measures needed but cannot be identified } \\
\text { Vul dit zo goed mogelijk in op basis van expert-kennis. Je kunt } \\
\text { ondersteunende bestanden gebruiken met een lijst van maatregelen. } \\
\text { Ook zijn er (incomplete) overzichten van PAS-maatregelen en LIFE- } \\
\text { projecten. }\end{array}$ \\
\hline $\begin{array}{l}8.2 \text { Main purpose of the } \\
\text { measures taken }\end{array}$ & $\begin{array}{l}\text { Indicate the main purpose of measures taken: } \\
\text { a) Maintain the current range, surface area or structure and functions } \\
\text { of the habitat type or } \\
\text { b) Expand the current range of the habitat type (related to 'Range') or } \\
\text { c) Increase the surface area of the habitat type (related to 'Area } \\
\text { covered by habitat') or } \\
\text { d) Restore the structure and functions, including the status of typical } \\
\text { species (related to 'Specific structure and functions') } \\
\text { Dit wordt niet ingevuld als er bij } 8.1 \text { een a) of c) is ingevuld. }\end{array}$ \\
\hline $\begin{array}{l}8.3 \text { Location of the measures } \\
\text { taken }\end{array}$ & $\begin{array}{l}\text { Indicate the location of measures taken: } \\
\text { a) Only inside Natura } 2000 \text { or } \\
\text { b) Both inside and outside Natura } 2000 \text { or } \\
\text { c) Only outside Natura } 2000 \\
\text { Dit wordt niet ingevuld als er bij } 8.1 \text { een a) of c) is ingevuld. }\end{array}$ \\
\hline $\begin{array}{l}\text { 8.4 Response to the measures } \\
\text { (when the measures starts to } \\
\text { neutralize the pressure(s) and } \\
\text { produce positive effects) }\end{array}$ & $\begin{array}{l}\text { Indicate the time frame of the response to measures (with regard to the main } \\
\text { purpose indicated in field 8.2): } \\
\text { a) Short-term results (within the current reporting period, 2013-2018) } \\
\text { or } \\
\text { b) Medium-term results (within the next two reporting periods, 2019- } \\
\text { 2030) or } \\
\text { c) Long-term results (after 2030) } \\
\text { Dit wordt alleen niet ingevuld als er bij } 8.1 \text { een c) is ingevuld. }\end{array}$ \\
\hline $\begin{array}{l}8.5 \text { List of main conservation } \\
\text { measures }\end{array}$ & $\begin{array}{l}\text { List a maximum of } 10 \text { measures using code list provided in the } \\
\text { Reference portal } \\
\text { Ook hiervoor is een voorzet gedaan. Corrigeer en vul aan naar eigen } \\
\text { inzicht. }\end{array}$ \\
\hline 8.6 Additional information & $\begin{array}{l}\text { Other relevant information, complementary to the data requested } \\
\text { under fields } 8.1-8.5 \\
\text { Free text } \\
\text { Als je nog specifieke literatuur of maatregelen wilt noemen, kan dat } \\
\text { hier. }\end{array}$ \\
\hline
\end{tabular}

\section{Future prospects}

In de guidelines staat een flow-diagram opgenomen dat doorlopen moet worden om te komen tot een beoordeling van de future propspects. In principe wijkt de beoordeling van het toekomstperspectief bij 9.1 niet af van de beoordeling van de verschillende parameters (a), (b) en (c), tenzij hier een goede aanleiding voor is. In dat laatste geval moet het onderbouwd worden bij 9.2. 


\begin{tabular}{|c|l|l|}
\hline $\begin{array}{c}\text { 9.1 Future prospects of } \\
\text { parameters }\end{array}$ & a) Range & Good / Poor / Bad / Unknown \\
\cline { 2 - 3 } & b) Area & Good / Poor / Bad / Unknown \\
\hline & $\begin{array}{l}\text { c) Structure and } \\
\text { functions }\end{array}$ & Good / Poor / Bad / Unknown \\
\hline Optional Additional information & $\begin{array}{l}\text { Other relevant information, complementary to the data requested under } \\
\text { field } 9.1\end{array}$ \\
$\begin{array}{l}\text { Free text } \\
\text { Vul hier de belangrijkste bedreigingen in die in de nabije toekomst } \\
\text { (komende 12 jaar) zullen aanhouden of verergeren. Geef hier ook een } \\
\text { toelichting, indien het toekomstperspectief positiever of negatiever is } \\
\text { gescoord dan op basis van de andere drie parameters. }\end{array}$ \\
\hline
\end{tabular}

\section{Conclusions}

Assessment of conservation status at end of reporting period

Gebruik hiervoor Annex E aan het eind van dit document. Vergelijk deze scores met die uit de vorige rapportage. Als er een verschil is, geef dan in 10.7 aan wat de oorzaak is.

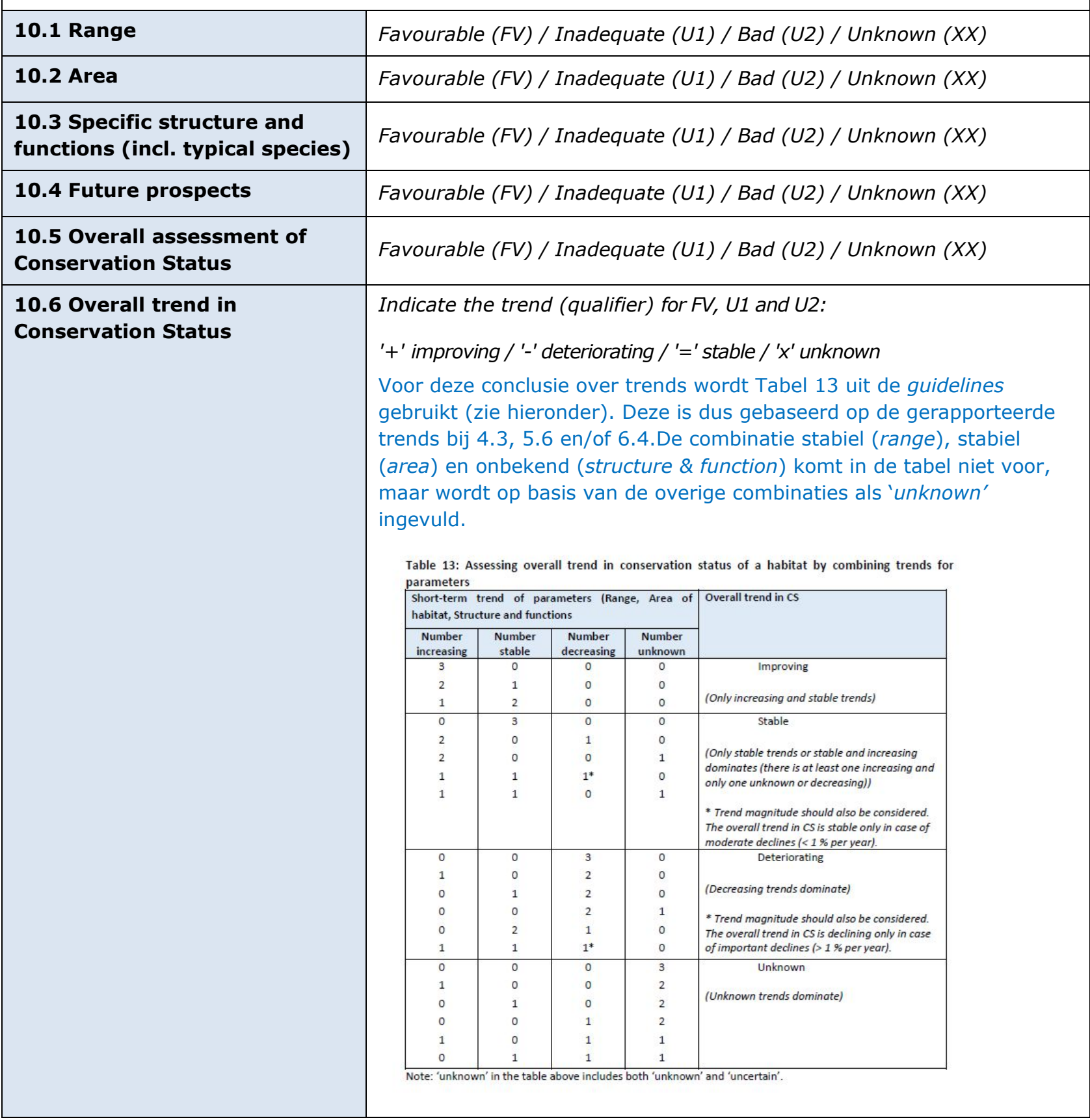




\begin{tabular}{|c|c|c|c|}
\hline \multirow[t]{8}{*}{$\begin{array}{l}\text { 10.7 Change and reasons for } \\
\text { change in conservation status } \\
\text { and conservation status trend }\end{array}$} & \multicolumn{3}{|c|}{$\begin{array}{l}\text { Indicate whether there is a change from the previous reporting round } \\
\text { and (if yes) the nature of that change. More than one option ( } b \text { to e) } \\
\text { can be chosen. }\end{array}$} \\
\hline & & $\begin{array}{l}\text { Overall } \\
\text { assessment of } \\
\text { conservation } \\
\text { status (10.5) }\end{array}$ & $\begin{array}{l}\text { Overall trend in } \\
\text { conservation } \\
\text { status (10.6) }\end{array}$ \\
\hline & $\begin{array}{l}\text { a) no, there is no } \\
\text { difference }\end{array}$ & $Y E S / N O$ & $Y E S / N O$ \\
\hline & $\begin{array}{l}\text { b) yes, due to genuine } \\
\text { change }\end{array}$ & $Y E S / N O$ & $Y E S / N O$ \\
\hline & $\begin{array}{l}\text { c) yes, due to improved } \\
\text { knowledge/more accurate }\end{array}$ & $Y E S / N O$ & $Y E S / N O$ \\
\hline & $\begin{array}{l}\text { d) yes, due to the use of } \\
\text { different methods } \\
\text { (including use of different } \\
\text { thresholds) }\end{array}$ & $Y E S / N O$ & $Y E S / N O$ \\
\hline & $\begin{array}{l}\text { e) yes, but there is no } \\
\text { information on nature of } \\
\text { change }\end{array}$ & $Y E S / N O$ & $Y E S / N O$ \\
\hline & $\begin{array}{l}\text { The change is mainly due } \\
\text { to (select one of the } \\
\text { reasons above): }\end{array}$ & $\begin{array}{l}\text { genuine change / } c \\
\text { / the use of a } \\
\text { different method }\end{array}$ & $\begin{array}{l}\text { genuine change / } \\
\text { improved } \\
\text { knowledge or more } \\
\text { accurate data / the } \\
\text { use of a different } \\
\text { method }\end{array}$ \\
\hline $\begin{array}{l}\text { 10.8 Additional information } \\
\text { Optional }\end{array}$ & \multicolumn{3}{|c|}{$\begin{array}{l}\text { Other relevant information, complementary to the data requested } \\
\text { under fields } 10.1-10.7 \\
\text { Free text } \\
\text { Geef hier aan hoe je de beoordeling van Structuur \& functie hebt } \\
\text { gedaan, op basis van de combinatie (i) habitattype in goede S\&F en (ii) } \\
\text { de beoordeling van typische soorten. }\end{array}$} \\
\hline
\end{tabular}

\section{Natura 2000 (pSCIs, SCIs, SACs) coverage for Annex I habitat types}

In het SDF-rapport (Janssen et al. 2014) staat een inschatting van de oppervlakte van de habitattypen binnen en buiten N2000. Je kunt deze waarden aanhouden, tenzij je betere informatie hebt.

\begin{tabular}{|l|l|l|}
\hline $\begin{array}{l}\text { 11.1 Surface area of the } \\
\text { habitat type inside the pSCIs, } \\
\text { SCIs and SACs network } \\
\text { (In } \mathrm{km}^{2} \text { in biogeographical/ } \\
\text { marine region) }\end{array}$ & a) Minimum & $\begin{array}{l}\text { Provide either interval (a and } b \text { ) and/or best single } \\
\text { value }(c) \\
\text { Niet invullen }\end{array}$ \\
\cline { 2 - 3 } & b) Maximum & $\begin{array}{l}\text { Provide either interval ( } a \text { and } b \text { ) and/or best single } \\
\text { value (c) } \\
\text { Niet invullen }\end{array}$ \\
\cline { 2 - 3 } & $\begin{array}{l}\text { c) Best single } \\
\text { value }\end{array}$ & $\begin{array}{l}\text { Provide either interval (a and } b \text { ) and/or best single } \\
\text { value (c) } \\
\text { Alleen deze invullen }\end{array}$ \\
\hline $\begin{array}{l}\text { 11.2 Type of estimate } \\
\text { Best estimate / 95\% confidence interval / minimum } \\
\text { Best estimate }\end{array}$ \\
\hline
\end{tabular}




\begin{tabular}{|c|c|}
\hline $\begin{array}{l}11.3 \text { Surface area of the } \\
\text { habitat type inside the network } \\
\text { Method used }\end{array}$ & $\begin{array}{l}\text { Select one of the following methods: } \\
\text { a) Complete survey or a statistically robust estimate } \\
\text { b) Based mainly on extrapolation from a limited amount of data } \\
\text { c) Based mainly on expert opinion with very limited data } \\
\text { d) Insufficient or no data available } \\
\text { Vrijwel altijd b) }\end{array}$ \\
\hline $\begin{array}{l}11.4 \text { Short-term trend of } \\
\text { habitat area in good condition } \\
\text { within the network } \\
\text { Direction }\end{array}$ & $\begin{array}{l}\text { Short-term trend of habitat area in good condition within the network } \\
\text { over the period indicated in the field 6.3: } \\
0=\text { stable } /+=\text { increasing } /-=\text { decreasing } / u=\text { uncertain } / x= \\
\text { unknown } \\
\text { Zelfde als } 6.4 \text { tenzij er een heel goede reden is om hiervan af te wijken. }\end{array}$ \\
\hline $\begin{array}{l}11.5 \text { Short-term trend of } \\
\text { habitat area in good condition } \\
\text { within network } \\
\text { Method used }\end{array}$ & $\begin{array}{l}\text { Select one of the following methods: } \\
\text { a) Complete survey or a statistically robust estimate } \\
\text { b) Based mainly on extrapolation from a limited amount of data } \\
\text { c) Based mainly on expert opinion with very limited data } \\
\text { d) Insufficient or no data available } \\
\text { Zelfde als } 6.5 \text { tenzij er een heel goede reden is om hiervan af te wijken. }\end{array}$ \\
\hline 11.6 Additional information & $\begin{array}{l}\text { Other relevant information, complementary to the data requested under } \\
\text { fields } 11.1-11.5 \\
\text { Free text } \\
\text { Standaardtekst: } \\
\text { Percentage area in and outside Natura 2000-network are based on } \\
\text { Janssen et al. (2014). }\end{array}$ \\
\hline
\end{tabular}

\section{Complementary information}

12.1 Justification of $\%$ thresholds for trends

Optional

12.2 Other relevant information
In case a MS is not using the indicative suggested value of $1 \%$ per year when assessing trends, this should be duly justified in this free text field

Standaardtekst:

$10 \%$ decrease/increase is used as threshold for all trends, due to uncertainty in data; a formula with $75 \% / 25 \%$-thresholds is used for conservation status of Structure \& Function and Typical species.

Other relevant information not specific for the sections of this format. Free text

Standaardtekst: Report by Naam (Organisatie) 


\section{Bijlage 3 Criteria voor toedeling van opnamen aan habitattypen t.b.v. verspreidingskaarten}

In de tabel staat aangegeven op basis van welke aanvullende criteria opnamen die tot een bepaalde plantengemeenschap (syntaxon) behoren worden toegedeeld aan de habitattypen, en welke Gisbestanden (kaart) daarvoor gebruikt worden.

\begin{tabular}{|c|c|c|c|c|c|c|c|c|c|c|c|c|}
\hline $\begin{array}{l}\text { habitat } \\
\text { type }\end{array}$ & $\mathrm{fgr}$ & ecodistrict & fysiotoop & oudebossen & $\begin{array}{l}\text { nietalshab } \\
\text { itattypeaa } \\
\text { nwezigis }\end{array}$ & syntaxon & $\begin{array}{l}\text { drempe } \\
\text { I_min_s } \\
\text { soortenl oorten }\end{array}$ & $\begin{array}{l}\text { drempel_ } \\
\text { max_soort } \\
\text { en }\end{array}$ & speciaal1 & speciaal2 & opmerking & kaart \\
\hline 1310 & & & & & & 25AA03 & & & & & & \\
\hline 1310 & & & & & & 25AA02 & & & & & & \\
\hline 1310 & & & & & & $27 A A 02 A$ & & & & & & \\
\hline 1310 & & & & & & 27AA01 & & & & & & \\
\hline 1330 & ('gg','du') & & -('zk2a,',zk2b', 'zk2c') & & & 26RG04 & & & & & & \\
\hline 1330 & & & & & & $26 \mathrm{ACO5}$ & & & & & & \\
\hline 1330 & ('gg','du') & & -('zk2a,',zk2b', 'zk2c') & & & $26 \mathrm{ACO}$ & & & & & & \\
\hline 1330 & ('gg','du') & & -('zk2a,','zk2b','zk2c') & & & $26 \mathrm{ACO} 2$ & & & & & & \\
\hline 1330 & ('gg','du') & & -('zk2a,',zk2b', 'zk2c') & & & $26 \mathrm{ACO} 1$ & & & & & & \\
\hline 1330 & ('gg','du') & & -('zk2a','zk2b','zk2c') & & & $26 \mathrm{ABO} 04$ & & & & & & \\
\hline 1330 & ('gg','du') & & -('zk2a','zk2b','zk2c') & & & $26 \mathrm{AB} 01$ & & & & & & \\
\hline 1330 & & & & & & 26AA03 & & & & & & \\
\hline 1330 & ('gg','du') & & -('zk2a','zk2b','zk2c') & & & $26 \mathrm{ACO} 4$ & & & & & & \\
\hline 1330 & ('gg','du') & & -('zk2a', 'zk2b', 'zk2c') & & & 26AC06 & & & & & & \\
\hline 1330 & ('gg','du') & & -('zk2a,',zk2b', 'zk2c') & & & $26 \mathrm{ACO}$ & & & & & & \\
\hline 1330 & ('gg','du') & & -('zk2a,','zk2b','zk2c') & & & 26RG01 & & & & & & \\
\hline 1330 & ('gg','du') & & -('zk2a,',zk2b', 'zk2c') & & & 26RG02 & & & & & & \\
\hline 1330 & ('gg','du') & & -('zk2a','zk2b','zk2c') & & & 26RG03 & & & & & & \\
\hline 1330 & ('gg','du') & & ('zk2a','zk2b','zk2c') & & & 26ACO6 & & & & & & \\
\hline 1330 & -('gg','du') & & & & & 26AA01 & & & & & & \\
\hline 1330 & ('gg','du') & & ('zk2a','zk2b','zk2c') & & & 26RG04 & & & & & & \\
\hline 1330 & ('gg','du') & & ('zk2a','zk2b','zk2c') & & & $26 \mathrm{RG} 03$ & & & & & & \\
\hline 1330 & ('gg','du') & & ('zk2a','zk2b','zk2c') & & & 26RG02 & & & & & & \\
\hline 1330 & ('gg','du') & & ('zk2a','zk2b','zk2c') & & & $26 \mathrm{ABO} 2$ & & & & & & \\
\hline 1330 & ('gg','du') & & ('zk2a','zk2b','zk2c') & & & $26 \mathrm{AB} 01$ & & & & & & \\
\hline 1330 & ('gg','du') & & ('zk2a','zk2b','zk2c') & & & 26AA01 & & & & & & \\
\hline 1330 & -('gg','du') & & & & & 26RG04 & & & & & & \\
\hline 1330 & -('gg','du') & & & & & 26RG03 & & & & & & \\
\hline 1330 & -('gg','du') & & & & & 26RG02 & & & & & & \\
\hline 1330 & -('gg','du') & & & & & 26RG01 & & & & & & \\
\hline 1330 & -('gg','du') & & & & & $26 \mathrm{ACO} 7$ & & & & & & \\
\hline 1330 & -('gg','du') & & & & & $26 \mathrm{ACO}$ & & & & & & \\
\hline 1330 & -('g','du') & & & & & $26 \mathrm{ACO} 4$ & & & & & & \\
\hline 1330 & -('gg','du') & & & & & $26 \mathrm{ACO}$ & & & & & & \\
\hline 1330 & -('gg','du') & & & & & $26 \mathrm{ACO} 2$ & & & & & & \\
\hline 1330 & -('gg','du') & & & & & $26 \mathrm{ACO} 1$ & & & & & & \\
\hline 1330 & -('gg','du') & & & & & $26 \mathrm{ABO} 04$ & & & & & & \\
\hline 1330 & -('gg','du') & & & & & $26 \mathrm{AB} 03$ & & & & & & \\
\hline 1330 & -('gg','du') & & & & & $26 \mathrm{ABO} 2$ & & & & & & \\
\hline 1330 & -('gg','du') & & & & & $26 \mathrm{AB} 01$ & & & & & & \\
\hline
\end{tabular}




\begin{tabular}{|c|c|c|c|c|c|c|c|c|c|c|c|c|c|}
\hline $\begin{array}{l}\text { habitat } \\
\text { type }\end{array}$ & $\mathrm{fgr}$ & ecodistrict & fysiotoop & oudebossen & $\begin{array}{l}\text { nietalshab } \\
\text { itattypeaa } \\
\text { nwezigis }\end{array}$ & syntaxon & & $\begin{array}{l}\text { drempe } \\
\text { I_min_s } \\
\text { | oorten }\end{array}$ & $\begin{array}{l}\text { drempel__ } \\
\text { max_soort } \\
\text { en }\end{array}$ & speciaal1 & speciaal2 & opmerking & kaа \\
\hline 2110 & ('du','gg') & $-134,163,174$ & & & & 23AA01 & & & & & & & \\
\hline 2120 & ('du') & $-134,163,174$ & & & & 23AB01 & & & & & & & \\
\hline 2130 & ('du') & $-134,163,174$ & & & & 17AA02 & & & & & & & \\
\hline 2130 & ('du') & $-134,163,174$ & & & & 14CA01 & & & & & & & \\
\hline 2130 & ('du') & $-134,163,174$ & & & & 14СBO1 & & & & & & & \\
\hline 2130 & ('du') & $-134,163,174$ & & & & $14 \mathrm{CAO} 3$ & & & & & & & \\
\hline 2130 & ('du') & $-134,163,174$ & & & & 14CA02 & & & & & & & \\
\hline 2130 & ('du') & $-134,163,174$ & & & & $14 \mathrm{CBO2}$ & & & & & & & \\
\hline 2130 & ('du') & $-134,163,174$ & & & & 14BB02A & & & & & & & \\
\hline 2130 & ('du') & $-134,163,174$ & & & & 14AA01 & & & & & & & \\
\hline 2130 & ('du') & $-134,163,174$ & & & & 14AA02 & & & & & & & \\
\hline 2130 & ('du') & $-134,163,174$ & & & & 14BВ02B & & & & & & & \\
\hline 2130 & ('du') & $-134,163,174$ & & & & 14BA01 & & & & & & & \\
\hline 2130 & ('du') & $-134,163,174$ & & & & $14 R G 03$ & & & & & & & \\
\hline 2130 & ('du') & $-134,163,174$ & & & & 14RG01 & & & & & & & \\
\hline 2130 & ('du') & $-134,163,174$ & & & & 14RG11 & & & & & & & \\
\hline 2130 & ('du') & $-134,163,174$ & & & & 19AA03 & & & & & & & \\
\hline 2130 & ('du') & $-134,163,174$ & & & & 19RG01 & & & & & & & \\
\hline 2140 & ('du') & & & & & 11AA03 & v & 1 & 1 & & & & \\
\hline 2140 & ('du') & & & & & $20 A B 03$ & v & 1 & 1 & & & & \\
\hline 2140 & ('du') & & & & & $20 A B 01$ & v & 1 & 1 & & & & \\
\hline 2140 & ('du') & & & & & 20ABO2 & v & 1 & 1 & & & & \\
\hline 2150 & ('du') & & & & & $20 A B 01$ & 1 & 1 & 1 & & & $\begin{array}{l}\text { Calluna > } 25 \% \text {; } \\
\text { Empetrum afwezig; }\end{array}$ & \\
\hline 2160 & ('du') & $-134,163,174$ & & & & 37ACO1 & AC & 1 & 1 & & & & \\
\hline 2160 & ('du') & $-134,163,174$ & & & & $37 \mathrm{ACO} 2$ & $A C$ & 1 & 1 & & & & \\
\hline 2160 & ('du') & $-134,163,174$ & & & & 37ACO3 & $A C$ & 1 & 1 & & & & \\
\hline 2160 & ('du') & $-134,163,174$ & & & & $37 R G 03$ & $A C$ & 1 & 1 & & & & \\
\hline 2160 & $\left(' d u^{\prime}\right)$ & $-134,163,174$ & & & & 37RG01 & $A C$ & 1 & 1 & & & & \\
\hline 2160 & ('du') & $-134,163,174$ & & & & $37 R G 02$ & $A C$ & 1 & 1 & & & & \\
\hline 2170 & ('du') & $-134,163,174$ & & & & $20 A B 04$ & & & & & & & \\
\hline 2170 & ('du') & $-134,163,174$ & & & & 36AA02C & DA & 1 & 1 & & & & \\
\hline 2170 & ('du') & $-134,163,174$ & & & & 09RG01 & DA & 1 & 1 & & & & \\
\hline 2180 & ('du') & & & & & 42AA03 & & & & & & & \\
\hline 2180 & ('du') & & & & & 42AA01 & & & & & & & \\
\hline 2180 & ('du') & & & & & 42AA02 & & & & & & & \\
\hline 2180 & ('du') & & & & & 39AA02 & & & & & & & \\
\hline 2180 & ('du') & & & & & 36AA02 & M & 1 & 1 & & & Betula pubescens $>50 \%$ & \\
\hline 2180 & ('du') & & & & & 43AA03 & & & & & & & \\
\hline 2180 & ('du') & & & & & 40AA02 & & & & & & & \\
\hline 2180 & ('du') & & & & & $39 R G 02$ & & & & & & & \\
\hline 2180 & ('du') & & & & & 39RG04 & & & & & & & \\
\hline 2180 & ('du') & & & & & $43 \mathrm{RGO3}$ & & & & & & & \\
\hline 2180 & ('du') & & & & & 40RG03 & & & & & & & \\
\hline 2180 & ('du') & & & & & 43AA01 & & & & & & & \\
\hline 2180 & ('du') & & & & & 43AA05 & & & & & & & \\
\hline 2180 & ('du') & & & & & 43AA02 & & & & & & & \\
\hline 2180 & ('du') & & & & & 43RG01 & & & & & & & \\
\hline 2180 & ('du') & & & & & $43 \mathrm{RGO2}$ & & & & & & & \\
\hline 2190 & ('du') & & & & & 04BA02 & $x$ & 1 & 1 & & & & \\
\hline 2190 & $\left(' d u^{\prime}\right)$ & & & & & 04BA03 & & & & & & & \\
\hline 2190 & ('du') & & & & & 04CA01 & & & & & & & \\
\hline 2190 & ('du') & & & & & 04Вв01 & & & & & & & \\
\hline 2190 & ('du') & & & & & 05AA01 & & & & & & & \\
\hline 2190 & ('du') & & & & & 29AA04 & & & & & & & \\
\hline 2190 & ('du') & & & & & $06 \mathrm{ACO} 4$ & & & & & & & \\
\hline 2190 & ('du') & & & & & $06 \mathrm{ACO2}$ & & & & & & & \\
\hline 2190 & ('du') & & & & & 06AC01 & & & & & & & \\
\hline 2190 & ('du') & & & & & $06 \mathrm{AB} 01$ & & & & & & & \\
\hline 2190 & ('du') & & & & & 05AA02 & & & & & & & \\
\hline 2190 & ('du') & & & & & 04ВB03 & & & & & & & \\
\hline 2190 & ('du') & & & & & 08AA01 & & & & & & & \\
\hline 2190 & ('du') & & & & & $06 \mathrm{ACO3}$ & & & & & & & \\
\hline 2190 & ('du') & & & & & О5САОЗ & & & & & & & \\
\hline 2190 & ('du') & & & & & 05RG03 & & & & & & & \\
\hline 2190 & ('du') & & & & & O4RG01 & & & & & & & \\
\hline 2190 & ('du') & & & & & 05RG01 & & & & & & & \\
\hline 2190 & ('du') & & & & & 06RG01 & & & & & & & \\
\hline
\end{tabular}




\begin{tabular}{|c|c|c|c|c|c|c|c|c|c|c|c|c|c|}
\hline $\begin{array}{l}\text { habitat } \\
\text { type }\end{array}$ & $\mathrm{fgr}$ & ecodistrict & fysiotoop & oudebossen & $\begin{array}{l}\text { nietalshab } \\
\text { itattypeaa } \\
\text { nwezigis }\end{array}$ & syntaxon & & $\begin{array}{l}\text { drempe } \\
\text { I_min_s } \\
\text { I oorten }\end{array}$ & $\begin{array}{l}\text { drempel_ } \\
\text { max_soort } \\
\text { en }\end{array}$ & speciaal1 & speciaal2 & opmerking & kaart \\
\hline 2190 & ('du','az') & $-(33)$ & & & & 27AA02C & & & & & & & \\
\hline 2190 & ('du','az') & $-(33)$ & & & & О9ВАОЗ & & & & & & & \\
\hline 2190 & ('du','az') & $-(33)$ & & & & 09вА04 & & & & & & & \\
\hline 2190 & ('du','az') & $-(33)$ & & & & 09BA05 & & & & & & & \\
\hline 2190 & ('du','az') & $-(33)$ & & & & $27 A A 02 B$ & & & & & & & \\
\hline 2190 & ('du','az') & $-(33)$ & & & & 09RG01 & & & & $1124<=50$ & & Salix repens $<=50 \%$ & \\
\hline 2190 & ('du','az') & $-(33)$ & & & & О9ААОЗА & & & & & & & \\
\hline 2190 & ('du','az') & $-(33)$ & & & & 11AA03 & $\mathrm{v}$ & & 0 & $\mathrm{p}$ & & & \\
\hline 2190 & ('du', 'az') & $-(33)$ & & & & 08RG06 & & & & & & & \\
\hline 2190 & ('du','az') & $-(33)$ & & & & O9AA01 & & & & & & & \\
\hline 2190 & ('du','az') & $-(33)$ & & & & 09RG03 & & & & & & & \\
\hline 2190 & ('du') & & & & & 08ввоз & & & & & & & \\
\hline 2190 & ('du') & & & & & $08 \mathrm{BD} 03$ & & & & & & & \\
\hline 2190 & ('du') & & & & & 08вв04 & & & & & & & \\
\hline 2190 & ('du') & & & & & 08BA02 & & & & & & & \\
\hline 2190 & ('du') & & & & & 08ВC01 & & & & & & & \\
\hline 2190 & ('du') & & & & & 08вC02 & & & & & & & \\
\hline 2190 & ('du') & & & & & 08BD02 & & & & & & & \\
\hline 2190 & ('du') & & & & & 08вв02 & & & & & & & \\
\hline 2190 & ('du') & & & & & 08AA01 & & & & & & & \\
\hline 2190 & ('du') & & & & & 08RG03 & & & & & & & \\
\hline 2190 & ('du') & & & & & $08 R G 06$ & & & & & & & \\
\hline 2190 & ('du') & & & & & 08RG07 & & & & & & & \\
\hline 2190 & ('du') & & & & & 08RG08 & & & & & & & \\
\hline 2190 & ('du') & & & & & 08RG02 & & & & & & & \\
\hline 2190 & ('du') & & & & & 08RG04 & & & & & & & \\
\hline 2310 & $-\left(' d u^{\prime}\right)$ & & & & & 20AA01 & & & & $186>447$ & & Struikhei > Kraaihei & Iandduinen \\
\hline 2310 & -('du') & & & & & 20AA02 & & & & $186>447$ & & Struikhei > Kraaihei & landduinen \\
\hline 2320 & $-\left(' d u^{\prime}\right)$ & & -('hz4a','hz4b','hz4c') & & & 20AA01 & & & & $447>=186$ & & Kraaihei >=Struikhei & \\
\hline 2320 & $-\left(d u^{\prime}\right)$ & & -('hz4a','hz4b', 'hz4c') & & & 20AA02 & & & & $447>=186$ & & Kraaihei $>=$ Struikhei & \\
\hline 2330 & -('du') & & & & & 14AA01 & & & & & & & landduinen \\
\hline 2330 & -('du') & & & & & 14RG03 & & & & & & & landduinen \\
\hline 3110 & -('du') & & & & & 06AA01 & & & & & & & \\
\hline 3130 & -('du') & & & & & $06 A B 01$ & & & & & & & top10_vennen_poelen \\
\hline 3130 & -('du') & & & & & $06 A B 02$ & & & & & & & top10_vennen_poelen \\
\hline 3130 & -('du') & & & & & 06AD01 & & & & & & & top10_vennen_poelen \\
\hline 3130 & -('du') & & & & & 06AC03 & & & & & & & top10_vennen_poelen \\
\hline 3130 & -('du') & & & & & 06AC04 & & & & & & & top10_vennen_poelen \\
\hline 3130 & -('du') & & & & & $06 \mathrm{ACO2}$ & & & & & & & top10_vennen_poelen \\
\hline 3130 & -('du') & & & & & 06AC01 & & & & & & & top10_vennen_poelen \\
\hline 3130 & -('du') & & & & & 06RG01 & & & & & & & top10_vennen_poelen \\
\hline 3130 & $-\left(d^{\prime} d u^{\prime}\right)$ & & -('hz4a','hz4b','hz4c') & & & 06RG03 & & & & & & & top10_vennen_poelen \\
\hline 3140 & -('du', 'ni') & & & & & 04BA02 & $x$ & 1 & 1 & & & & \\
\hline 3140 & -('du', 'ni') & & & & & O4CA01 & $x$ & 1 & 1 & & & & \\
\hline 3140 & -('du', 'ni') & & & & & 04BA03 & $x$ & 1 & 1 & & & & \\
\hline 3140 & -('du', 'ni') & & & & & 04AA01 & $x$ & 1 & 1 & & & & \\
\hline 3140 & -('du', 'ni') & & & & & O4BA01 & $x$ & 1 & 1 & & & & \\
\hline 3150 & ('az','ri','lv') & & & & & 05вв02 & & & & -(sloten) & & & watervlak2b \\
\hline 3150 & ('az','ri','lv') & & & & & 05ВА01 & & & & -(sloten) & & & watervlak2b \\
\hline 3150 & ('az','ri','lv') & & & & & 05ВА02 & & & & -(sloten) & & & watervlak2b \\
\hline 3150 & ('az','ri','lv') & & & & & 05вв01 & & & & -(sloten) & & & watervlak2b \\
\hline 3150 & ('az', ri','lv') & & & & & 05ВА04 & A & 1 & 1 & -(sloten) & & $\begin{array}{l}\text { Mits breedbladige } \\
\text { fonteinkruiden aanwezig } \\
\text { (lijst A); }\end{array}$ & watervlak2b \\
\hline 3150 & ('az','ri','lv') & & & & & О5ВАОЗ & A & 1 & 1 & -(sloten) & & $\begin{array}{l}\text { Mits breedbladige } \\
\text { fonteinkruiden aanwezig } \\
\text { (lijst A); }\end{array}$ & watervlak2b \\
\hline 3160 & $-\left(' d u^{\prime}\right)$ & & -('hz4a','hz4b', 'hz4c') & & & 10AA03 & & & & & & $\begin{array}{l}\text { In vennen \& buiten het } \\
\text { Hoogveen }\end{array}$ & top10_vennen_poelen \\
\hline 3160 & $-\left(' d u^{\prime}\right)$ & & -('hz4a','hz4b','hz4c') & & & 10AA02 & & & & & & $\begin{array}{l}\text { In vennen \& buiten het } \\
\text { Hoogveen }\end{array}$ & top10_vennen_poelen \\
\hline 3160 & -('du') & & -('hz4a','hz4b', 'hz4c') & & & 10AA01 & & & & & & $\begin{array}{l}\text { In vennen \& buiten het } \\
\text { Hoogveen }\end{array}$ & top10_vennen_poelen \\
\hline 3160 & -('du') & & -('hz4a','hz4b', 'hz4c') & & & 10AB01 & & & & & & $\begin{array}{l}\text { In vennen \& buiten het } \\
\text { Hoogveen }\end{array}$ & top10_vennen_poelen \\
\hline 3260 & & & $\begin{array}{l}\text { ('hl3c','hl3d', 'hz5g', 'hz5a', 'hl3a','h } \\
\text { z5e') }\end{array}$ & & & $05 \mathrm{CAO3}$ & & & & & & & \\
\hline 3260 & & & & & & $05 \mathrm{CAO} 4$ & & & & & & & \\
\hline 3260 & -('du') & & & & & 05CA02 & & & & & & & water3 \\
\hline 3260 & & & $\begin{array}{l}\text { ('hl3c','hl3d','hz5g','hz5a','hl3a','h } \\
\text { z5e') }\end{array}$ & & & 05CA02 & & & & & & & \\
\hline 3260 & $-\left({ }^{\prime} d u^{\prime}\right)$ & & & & & $05 \mathrm{CAO3}$ & & & & & & & water3 \\
\hline 3260 & -('du') & & & & & 05CA01 & & & & & & & water3 \\
\hline 3260 & & & $\begin{array}{l}\text { ('hl3c','hl3d','hz5g', 'hz5a','hl3a','h } \\
\text { z5e') }\end{array}$ & & & 05RG08 & & & & & & & \\
\hline 3260 & -('du') & & & & & 05ВС01 & & & & & & & water3 \\
\hline 3260 & ('ri','zk') & & $\begin{array}{l}\text { ('ri1a','ri16','ri1c','ri2a','ri2b','ri2c } \\
\text { ','ri2d','rize','zk4a','zk4b') }\end{array}$ & & & 05ВA01 & & & & & & $\begin{array}{l}\text { In rivierlopen (incl. } \\
\text { nevengeulen) }\end{array}$ & \\
\hline
\end{tabular}




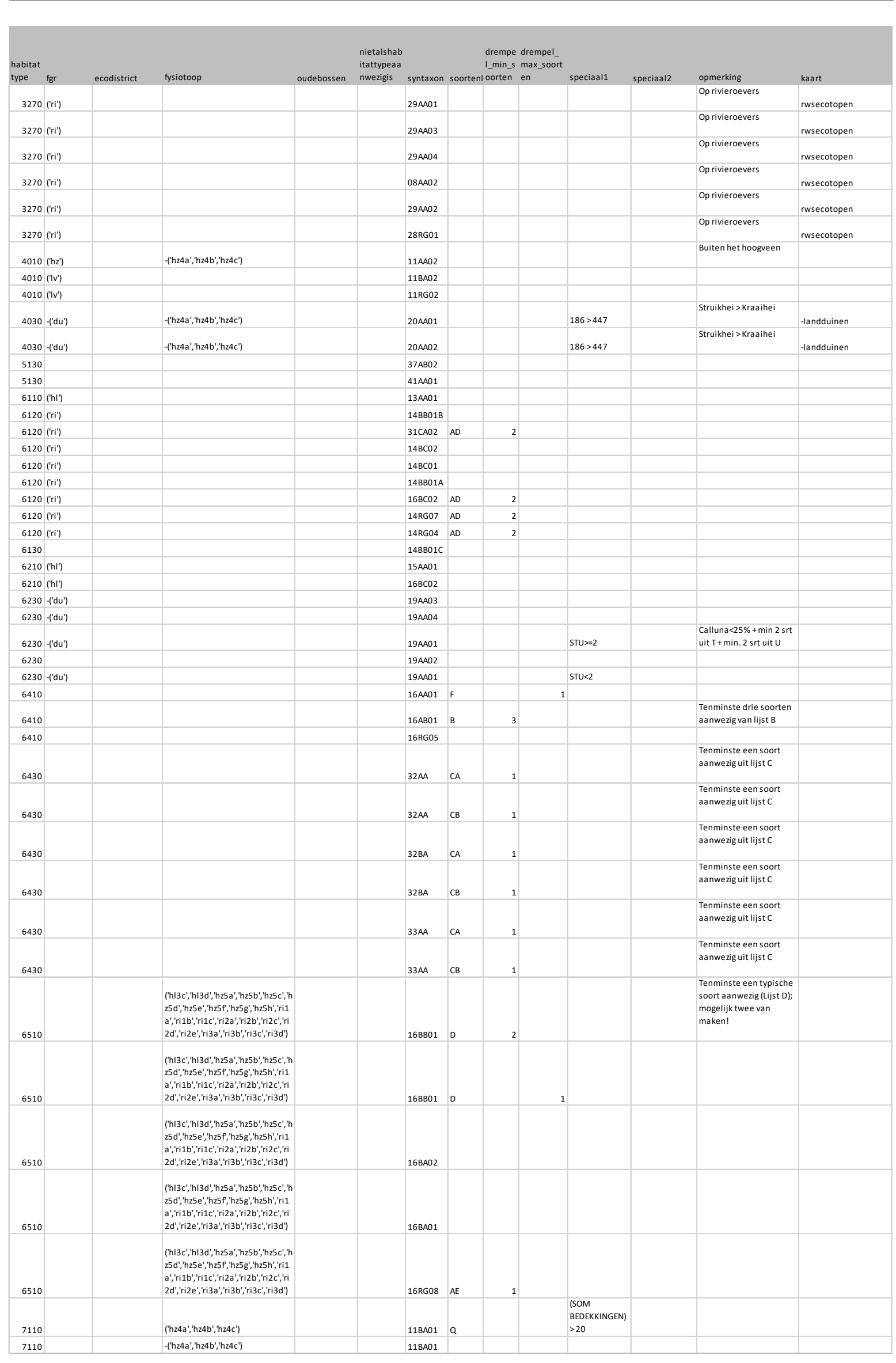




\begin{tabular}{|c|c|c|c|c|c|c|c|c|c|c|c|c|c|}
\hline $\begin{array}{l}\text { habitat } \\
\text { type }\end{array}$ & $\mathrm{fgr}$ & ecodistrict & fysiotoop & oudebossen & $\begin{array}{l}\text { nietalshab } \\
\text { itattypeaa } \\
\text { nwezigis }\end{array}$ & syntaxon & & $\begin{array}{l}\text { drempe } \\
\text { I_min_s } \\
\text { Il oorten }\end{array}$ & $\begin{array}{l}\text { e drempel_ } \\
\text { s max_soort } \\
\text { en }\end{array}$ & speciaal1 & speciaal2 & opmerking & kaart \\
\hline 7120 & & & ('hz4a','hz4b','hz4c') & & & 10AA01 & & & & & & & \\
\hline 7120 & & & ('hz4a','hz4b','hz4c') & & 7110 & 11BA01 & a & & & $\begin{array}{l}\text { (SOM } \\
\text { BEDEKKINGEN) } \\
>20\end{array}$ & & & \\
\hline 7120 & & & ('hz4a','hz4b','hz4c') & & & 20AA02 & & & & & & & \\
\hline 7120 & & & ('hz4a','hz4b','hz4c') & & & 10AA03 & & & & & & & \\
\hline 7120 & & & ('hz4a','hz4b','hz4c') & & & 10AA02 & & & & & & & \\
\hline 7120 & & & ('hz4a','hz4b','hz4c') & & & 11AA02 & & & & & & & \\
\hline 7120 & & & ('hz4a','hz4b','hz4c') & & & 40AA01 & & & & & & & \\
\hline 7120 & & & ('hz4a','hz4b','hz4c') & & & 10RG03 & & & & & & & \\
\hline 7120 & & & ('hz4a','hz4b','hz4c') & & & 06RG03 & & & & & & & \\
\hline 7120 & & & ('hz4a','hz4b','hz4c') & & & 06RG04 & & & & & & & \\
\hline 7120 & & & ('hz4a','hz4b','hz4c') & & & 10RG01 & & & & & & & \\
\hline 7120 & & & ('hz4a','hz4b','hz4c') & & & 10RG02 & & & & & & & \\
\hline 7120 & & & ('hz4a','hz4b','hz4c') & & & 10RG04 & & & & & & & \\
\hline 7120 & & & ('hz4a','hz4b','hz4c') & & & 11AA01 & & & & & & & \\
\hline 7120 & & & ('hz4a','hz4b','hz4c') & & 7110 & 11BA01 & a & & & $\begin{array}{l}\text { (SOM } \\
\text { BEDEKKINGEN) } \\
<=20\end{array}$ & & & \\
\hline 7140 & & & & & & 09АА०3B & & & & & & & \\
\hline 7140 & & & & & & 09BA01 & & & & & & & \\
\hline 7140 & & & & & & O9AA03A & 0 & & & $\begin{array}{l}\text { (SOM } \\
\text { BEDEKKINGEN) } \\
>20\end{array}$ & & Sphagnum $>20 \%$ & \\
\hline 7140 & & & & & & 09AA02 & & & & & & - & \\
\hline 7140 & ('Iv') & & & & & 09RG03 & & & & & & & \\
\hline 7150 & -('du') & & -('hz4a','hz4b','hz4c') & & & 11AA01 & & & & $\begin{array}{l}832,473,186< \\
25\end{array}$ & & $\begin{array}{l}\text { Molinia,Erica,Calluna < } \\
25 \%\end{array}$ & \\
\hline 7210 & & & & & & 08BD01 & E & 2 & 2 & & & $\begin{array}{l}\text { Meer dan } 1 \text { soort } \\
\text { aanwezig uit lijst E }\end{array}$ & \\
\hline 7210 & & & & & & 08BD01 & & & & & & $\begin{array}{l}\text { Nul of een soort uit lijst E } \\
\text { aanwezig }\end{array}$ & \\
\hline 7220 & ('hl') & & & & & $07 \mathrm{AAO} 2 \mathrm{C}$ & $\mathrm{K}$ & 2 & 2 & & & $\begin{array}{l}\text { Bron +Cratoneuron } \\
\text { commutatum aanwezig }\end{array}$ & \\
\hline 7230 & -('du','az') & & & & & 09BA & G & 1 & 1 & & & $\begin{array}{l}\text { met Carex flava en/of } \\
\text { Carex lepidocarpa }\end{array}$ & \\
\hline 7230 & -('du','az') & & & & & $16 \mathrm{~A}$ & G & 1 & 1 & & & $\begin{array}{l}\text { met Carex flava en/of } \\
\text { Carex lepidocarpa }\end{array}$ & \\
\hline 7230 & & & & & & 09BA02 & & & & & & & \\
\hline 7230 & & & & & & 16AA0 1 & $F$ & 2 & 2 & & & $\begin{array}{l}\text { met aanwezigheid van } \\
\text { twee soorten van Lijst F }\end{array}$ & \\
\hline 7230 & -('du', 'az') & & & & & 09BA05 & & & & & & & \\
\hline 9110 & ('hl') & & & & & $42 \mathrm{AB} 01$ & & & & & & & vuursteeneluvium \\
\hline 9120 & & & & h9120 $>=2$ & & $42 \mathrm{AA03}$ & & & & $\begin{array}{l}1036+1037> \\
943\end{array}$ & & $\begin{array}{l}\text { Quercus }>\text { Pinus } \\
\text { sylvestris }\end{array}$ & -vuursteeneluvium \\
\hline 9120 & & & & h9120>=2 & & 42AAO2 & & & & $\begin{array}{l}1036+1037> \\
943\end{array}$ & & $\begin{array}{l}\text { Quercus }>\text { Pinus } \\
\text { sylvestris }\end{array}$ & -vuursteeneluvium \\
\hline 9160 & ('hz') & & & & & $43 A B 01 F$ & $\mathrm{CP}$ & 1 & 1 & & & & \\
\hline 9160 & ('hz') & & & & & $43 A B 01 C$ & & & & & & & \\
\hline 9160 & ('hz') & & & & & 43ABO1E & & & & & & & \\
\hline 9160 & ('hl') & & & & & 43ABO1 & & & & & & & \\
\hline 9160 & ('hl') & & & & & $37 A C 05$ & & & & & & & \\
\hline 9190 & & & & h9190 $=2$ & & 42AA01 & & & & $\begin{array}{l}1036+1037> \\
943\end{array}$ & & $\begin{array}{l}\text { Quercus }>\text { Pinus } \\
\text { sylvestris }\end{array}$ & \\
\hline 9100 & $-\left(d u^{\prime}\right)$ & & & & & 40AA02 & 0 & 1 & 1 & $\begin{array}{l}\text { (SOM } \\
\text { BEDEKKINGEN) } \\
>50\end{array}$ & Molinia < 25 & $\begin{array}{l}\text { Sphagmum }>50 \% \text { en } \\
\text { Molinia }<25 \%\end{array}$ & \\
\hline 91D0 & -('du') & & -('hz4a','hz4b','hz4c') & & & 40AA01 & $z$ & 1 & 1 & & & & \\
\hline 91D0 & -('du') & & -('hz4a','hz4b','hz4c') & & & 40AA02 & z & 1 & 1 & & & & \\
\hline $91 \mathrm{D0}$ & -('du') & & & & & 40AA01 & 0 & 1 & 1 & $\begin{array}{l}\text { (SOM } \\
\text { BEDEKKINGEN) } \\
>50\end{array}$ & Molinia < 25 & $\begin{array}{l}\text { Sphagmum }>50 \% \text { en } \\
\text { Molinia }<25 \%\end{array}$ & \\
\hline 9100 & -('du') & & -('hz4a','hz4b','hz44') & & & 40RG03 & $z$ & 1 & 1 & & & & \\
\hline 9100 & -('du') & & -('hz4a','hz4b','hz4c') & & & 40RG01 & $z$ & 1 & 1. & & & & \\
\hline 91Do & $-($ 'du') & & -('hz4a','hz4b','hz4c') & & & 40RG02 & z & 1 & 1 & & & & \\
\hline $91 E 0$ & ('ri', 'zk', 'az') & & & & & 38AA02 & AA & 1 & 1 & & & & \\
\hline 91E0 & ('ri', 'zk', 'az') & & & & & 38AA01 & AA & 1 & 1. & & & & \\
\hline 91E0 & ('ri', 'zk','az') & & & & & 38АA03 & AA & 1 & 1 & & & & \\
\hline 91E0 & ('ri', 'zk', 'az') & & & & & 38DG01 & AA & 1 & 1 & & & & \\
\hline 91E0 & ('ri') & & & & & 38RG01 & AA & 1 & 1 & & & & \\
\hline $91 \mathrm{EO}$ & ('ri') & & & & & 43AA02 & & & & & & & \\
\hline 91E0 & ('ri') & & & & & 43RG01 & & & & & & & \\
\hline 91E0 & -('du') & & $\begin{array}{l}\text { ('hl3a', } \\
\text { 'hl3c',hl3d','h25a','hz5b','h25c','h } \\
\text { z5d','hz5e','hz5f','hz5g','h25h') }\end{array}$ & & & 39AA02 & & & & & & & \\
\hline 91E0 & -('du') & & 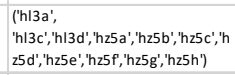 & & & 43АA04 & & & & & & & \\
\hline $91 E 0$ & $-\left(d u^{\prime}\right)$ & & $\begin{array}{l}\text { ('hl3a', } \\
\text { 'hl3c','hl3d','h25a','hz56','h25c','h } \\
\text { z5d',hz5e','hz5f,'hz25g','h25h') }\end{array}$ & & & 43AA05 & & & & & & & \\
\hline 91E0 & -('du') & & $\begin{array}{l}\text { ('hl3a', } \\
\text { 'hl3c',hl3d',',h25a','hz5b', 'h25c','h } \\
\text { z5d','hz5e','h25f','hz5g','h25h') }\end{array}$ & & & 39RG01 & & & & & & & \\
\hline 91E0 & $-\left(d^{\prime} u^{\prime}\right)$ & & $\begin{array}{l}\text { ('hl3a', } \\
\text { 'hl3c','h13d','h25a','hz5b','h25c',h } \\
\text { z5d',hz5e','h25f','hz5g','h25h') }\end{array}$ & & & $39 R G 03$ & & & & & & & \\
\hline $91 E 0$ & $-\left(d^{\prime} u^{\prime}\right)$ & & 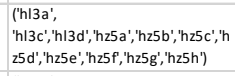 & & & $39 R G 04$ & & & & & & & \\
\hline 91E0 & -('du') & & 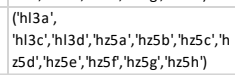 & & & 39RG02 & & & & & & & \\
\hline $91 E 0$ & -('du') & & 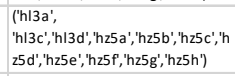 & & & 43RG03 & & & & & & & \\
\hline 91F0 & & & & & & 43AA01B & & & & & & & \\
\hline
\end{tabular}




\section{Bijlage 4 Resultaten verspreidingskaarten habitattypen}

In de tabel staat per habitattype de in 2019 gerapporteerde oppervlakte van het verspreidingsgebied weergegeven (kolom 2), met daarachter de gecorrigeerde (kolom 3) en gerapporteerde (kolom 4) oppervlakte van het verspreidingsgebied van de rapportage uit 2013. In de laatste kolom staat de in 2019 gerapporteerde trend, op basis van het verschil tussen de waarden in kolom 2 en kolom 3, waarbij een onzekerheidsmarge van $10 \%$ is gehanteerd (zie $\S 2.3$ ).

\begin{tabular}{|c|c|c|c|c|}
\hline Habitat code & Range area 2019 & $\begin{array}{l}\text { Range area } 2013 \\
\text { gecorrigeerd }\end{array}$ & $\begin{array}{l}\text { Range area } 2013 \\
\text { gerapporteerd }\end{array}$ & Trend 2019 \\
\hline 1110 & 23600 & 24100 & 24100 & 0 \\
\hline 1130 & 1700 & 1700 & 1700 & 0 \\
\hline 1140 & 7900 & 7800 & 7800 & 0 \\
\hline 1160 & 1100 & 1100 & 1100 & 0 \\
\hline 1170 & 3000 & 3100 & 3100 & 0 \\
\hline 1310 & 6700 & 6800 & 6800 & 0 \\
\hline 1320 & 5800 & 5600 & 5600 & 0 \\
\hline 1330 & 8100 & 8200 & 8200 & 0 \\
\hline 2110 & 5900 & 5700 & 4700 & 0 \\
\hline 2120 & 5800 & 5700 & 5000 & 0 \\
\hline 2130 & 5900 & 5400 & 5400 & 0 \\
\hline 2140 & 1900 & 1800 & 1800 & 0 \\
\hline 2150 & 2200 & 2200 & 2200 & 0 \\
\hline 2160 & 6200 & 6100 & 5600 & 0 \\
\hline 2170 & 4100 & 4300 & 4300 & 0 \\
\hline 2180 & 4800 & 4800 & 4800 & 0 \\
\hline 2190 & 7500 & 7100 & 7100 & 0 \\
\hline 2310 & 12300 & 11800 & 11800 & 0 \\
\hline 2320 & 4400 & 4400 & 4400 & 0 \\
\hline 2330 & 8400 & 7900 & 7600 & 0 \\
\hline 3110 & 700 & 900 & 800 & - \\
\hline 3130 & 10900 & 10500 & 8700 & 0 \\
\hline 3140 & 6200 & 6200 & 4400 & 0 \\
\hline 3150 & 10400 & 10100 & 10100 & 0 \\
\hline 3160 & 6300 & 6600 & 6600 & 0 \\
\hline 3260 & 5100 & 5600 & 4700 & 0 \\
\hline 3270 & 5500 & 5100 & 5100 & 0 \\
\hline 4010 & 16500 & 16300 & 16300 & 0 \\
\hline 4030 & 17300 & 16900 & 16100 & 0 \\
\hline 5130 & 5400 & 5200 & 5200 & 0 \\
\hline 6110 & 300 & 300 & 400 & 0 \\
\hline 6120 & 3700 & 3800 & 3800 & 0 \\
\hline 6130 & 100 & 100 & 100 & 0 \\
\hline 6210 & 500 & 500 & 600 & 0 \\
\hline 6230 & 13200 & 12600 & 12600 & 0 \\
\hline 6410 & 12000 & 11900 & 10900 & 0 \\
\hline 6430 & 28100 & 28300 & 28300 & 0 \\
\hline
\end{tabular}




\begin{tabular}{lllll}
\hline $\mathbf{6 5 1 0}$ & 9200 & 7100 & 6600 & 0 \\
$\mathbf{7 1 1 0}$ & 5500 & 5600 & 5100 & 0 \\
$\mathbf{7 1 2 0}$ & 4000 & 3700 & 3700 & 0 \\
$\mathbf{7 1 4 0}$ & 6700 & 7000 & 7000 & 0 \\
$\mathbf{7 1 5 0}$ & 12900 & 12400 & 11900 & 0 \\
$\mathbf{7 2 1 0}$ & 4400 & 4400 & 4200 & 0 \\
$\mathbf{7 2 2 0}$ & 500 & 500 & 600 & 0 \\
$\mathbf{7 2 3 0}$ & 2200 & 2100 & 2100 & 0 \\
$\mathbf{9 1 1 0}$ & 400 & 400 & 400 & 0 \\
$\mathbf{9 1 2 0}$ & 14800 & 15600 & 15600 & 0 \\
$\mathbf{9 1 6 0}$ & 5800 & 5400 & 5400 & 0 \\
$\mathbf{9 1 9 0}$ & 7700 & 8400 & 6500 & 0 \\
$\mathbf{9 1 D 0}$ & 8300 & 7700 & 7700 & 0 \\
$\mathbf{9 1 E 0}$ & 16100 & 16000 & 14800 & 0 \\
$\mathbf{9 1 F 0}$ & 1700 & 1800 & 1800 & 0
\end{tabular}




\section{Bijlage 5 Verschillen in landelijke oppervlakte habitattypen in kaarten uit 2013 en 2017}

In de tabel staat per habitattype (en subtypes) aangegeven wat de oppervlakte is op basis van een landelijke habitatkaart (Aerius-versie) uit 2017 (gecorrigeerd voor het aandeel buiten de Natura2000gebieden), en hoe de oppervlakte is gerapporteerd en berekend in 2013. Het verschil tussen de oppervlakte in 2017 (kolom 6) en 2013 (kolom 8) is aangegeven in kolom 7 in rood. De oorzaken van de (soms enorme) verschillen zijn niet duidelijk. Ze kunnen zitten in andere interpretaties van habitattypen, andere basisgegevens (vegetatiekaarten) voor de habitatkaarten (waarbij onduidelijk is welk deel van de kaarten is goedgekeurd) en daadwerkelijke veranderingen. Let ook op de hoeveelheid "zoekgebied" (kolom 4) waarvan het onduidelijk is of het tot een habitattype moet worden gerekend. Vanwege al deze onzekerheden is geen geüpdatete waarde voor de landelijke oppervlakte gerapporteerd ten opzichte van de rapportage uit 2013.

\begin{tabular}{|c|c|c|c|c|c|c|c|c|c|}
\hline Code & $\begin{array}{l}\text { Sub } \\
\text { type }\end{array}$ & $\begin{array}{l}\text { Habitat } \\
\text { kaart } \\
\text { N2000- } \\
\text { gebieden } \\
2017\end{array}$ & $\begin{array}{l}\text { Zoekgebie } \\
\text { d (aan } \\
\text { vullend) }\end{array}$ & $\begin{array}{l}\% \\
\text { buite } \\
\text { n HR }\end{array}$ & $\begin{array}{l}\text { Landelijk } \\
\text { e opp. } \\
2017\end{array}$ & $\begin{array}{l}\text { VERSCHIL } \\
\text { t.o.v. } \\
2013(\%)\end{array}$ & $\begin{array}{l}\text { Landelijk } \\
\text { e opp. } \\
\text { SDF- } \\
\text { rapport }\end{array}$ & $\begin{array}{l}\text { Opp. } \\
\text { N2000- } \\
\text { gebiede } \\
\text { n SDF- } \\
\text { rapport }\end{array}$ & $\begin{array}{l}\text { Opmerkin } \\
\text { g }\end{array}$ \\
\hline 1110 & totaal & 3410 & 0 & 0 & 3410 & -72 & 12156 & 12156.41 & \\
\hline 1110 & A & 1096 & 0 & 0 & 1096 & & & 1429.13 & $* 2$ \\
\hline 1110 & B & 2314 & 0 & 0 & 2314 & & & 5900 & $* 2$ \\
\hline 1110 & C & ontbreekt & 0 & 10 & & & & 4387.28 & \\
\hline 1130 & & 426 & 0 & 0 & 426 & -3 & 437 & 436.64 & \\
\hline \multirow[t]{3}{*}{1140} & totaal & 1401 & 0 & 2 & 1430 & -16 & 1700 & 1677.3 & \\
\hline & A & 1341 & 0 & & & & & & \\
\hline & B & 60 & 0 & & & & & & \\
\hline 1160 & & 342 & 0 & 0 & 342 & -1 & 347 & 347 & \\
\hline 1170 & & ontbreekt & 0 & 14 & & & 720 & 618.82 & $* 11$ \\
\hline \multirow[t]{3}{*}{1310} & totaal & 30.5 & 0 & 0 & 31 & 33 & 23 & 22.99 & \\
\hline & A & 29.1 & 0 & & & & & & \\
\hline & B & 1.4 & 0 & & & & & & \\
\hline 1320 & & 8.4 & 9.4 & 0 & 8.4 & 12 & 7.5 & 7.47 & \\
\hline \multirow[t]{3}{*}{1330} & totaal & 92.1 & 0 & 0 & 92 & -13 & 106 & 105.83 & \\
\hline & A & 84 & 0 & & & & & & \\
\hline & B & 8.1 & 0 & & & & & & \\
\hline 2110 & & 6.8 & 0.01 & 0 & 6.8 & 5 & 6.5 & 6.46 & \\
\hline 2120 & & 30 & 4.2 & 0 & 30 & 58 & 19 & 19.16 & \\
\hline \multirow[t]{4}{*}{2130} & totaal & 87.7 & 5.5 & 0 & 88 & -46 & 163 & 163.47 & \\
\hline & A & 40.3 & 1.2 & & & & & & \\
\hline & B & 45.9 & 4.3 & & & & & & \\
\hline & C & 1.5 & 0 & & & & & & \\
\hline \multirow[t]{3}{*}{2140} & totaal & 14.7 & 0 & 0 & 15 & -41 & 25 & 24.87 & \\
\hline & A & 1.5 & 0 & & & & & & \\
\hline & B & 13.2 & 0 & & & & & & \\
\hline 2150 & & 1.7 & 0 & 5 & 1.8 & -57 & 4.2 & 4 & \\
\hline 2160 & & 48.3 & 2.1 & 5 & 51 & -38 & 82 & 77.91 & \\
\hline 2170 & & 5.4 & 0.4 & 5 & 5.7 & -39 & 9.3 & 8.86 & \\
\hline 2180 & & 55.4 & 2.3 & 10 & 62 & -24 & 81 & 72.72 & \\
\hline & A & 34.7 & 1.6 & & & & & & \\
\hline & B & 7.6 & 0.3 & & & & & & \\
\hline & C & 13.1 & 0.4 & & & & & & \\
\hline 2190 & & 17 & 0.3 & 2 & 17 & -36 & 27 & 26.71 & \\
\hline
\end{tabular}




\begin{tabular}{|c|c|c|c|c|c|c|c|c|c|}
\hline & A & 2.8 & 0 & & & & & & \\
\hline & B & 9 & 0.1 & & & & & & \\
\hline & $\mathrm{C}$ & 1.6 & 0.1 & & & & & & \\
\hline & $D$ & 3.6 & 0.1 & & & & & & \\
\hline 2310 & & 25.3 & 0.3 & 25 & 34 & 5 & 32 & 24 & \\
\hline 2320 & & 3 & 0 & 25 & 4.0 & -51 & 8.2 & 6.15 & \\
\hline 2330 & & 29.1 & 0.1 & 25 & 39 & -9 & 43 & 31.93 & \\
\hline 3110 & & 0.7 & 0 & 5 & 0.7 & 195 & 0.25 & 0.241 & $* 3$ \\
\hline 3130 & & 2.9 & 0.4 & 20 & 3.6 & -14 & 4.2 & 3.36 & \\
\hline 3140 & & 79.8 & 0.9 & 10 & 89 & -3 & 92 & 82.55 & \\
\hline 3150 & & 21.8 & 26 & 20 & 27 & -28 & 38 & 30.54 & \\
\hline 3160 & & 4.2 & 0.1 & 30 & 6.0 & -14 & 6.95 & 4.87 & \\
\hline \multirow[t]{3}{*}{3260} & totaal & 1.3 & 0.3 & & 1.3 & 8 & 1.2 & 0.9 & \\
\hline & $A$ & 0.8 & 0.3 & 60 & & & & 0.15 & \\
\hline & B & 0.5 & 0 & 10 & & & & 0.75 & \\
\hline 3270 & & 1 & 10.3 & 18 & 1.2 & -47 & 2.3 & 1.9 & \\
\hline \multirow[t]{3}{*}{4010} & totaal & 16.4 & 0.1 & & 16 & 26 & 13 & 9.4 & $* 6$ \\
\hline & A & 14.8 & 0.1 & 30 & & & & 7.75 & \\
\hline & B & 1.6 & 0 & 10 & & & & 1.62 & \\
\hline 4030 & & 150.5 & 4.4 & 25 & 201 & -12 & 227 & 170 & \\
\hline 5130 & & 2.4 & 0 & 25 & 3.2 & -38 & 5.2 & 3.9 & \\
\hline 6110 & & 0.02 & 0.004 & 0 & 0.0200 & 3233 & 0.0006 & 0.0006 & \\
\hline 6120 & & 0.8 & 0.05 & 30 & 1.1 & -54 & 2.5 & 1.76 & \\
\hline 6130 & & 0.02 & 0 & 0 & 0.0200 & 233 & 0.006 & 0.0058 & \\
\hline 6210 & & 1.03 & 0.01 & 0 & 1.0 & 106 & 0.5 & 0.5 & \\
\hline 6230 & & 4.42 & 0.2 & 0 & 4.4 & -43 & 7.7 & 5.42 & \\
\hline 6410 & & 1.8 & 0.1 & 15 & 2.1 & -27 & 2.9 & 2.43 & \\
\hline \multirow[t]{4}{*}{6430} & & 13.1 & 12 & 40 & 22 & -9 & 24 & 14 & \\
\hline & $A$ & 3.5 & 2 & & & & & & \\
\hline & B & 3.8 & 9.4 & & & & & & \\
\hline & C & 0.2 & 0 & & & & & & \\
\hline \multirow[t]{3}{*}{6510} & & 5.6 & 0.6 & 20 & 7.0 & -21 & 8.9 & 7.16 & $* 7$ \\
\hline & $A$ & 3.6 & 0.6 & & & & & & \\
\hline & B & 2 & 0 & & & & & & \\
\hline \multirow[t]{3}{*}{7110} & & 0.7 & 0 & 5 & 0.7 & -39 & 1.2 & 1.18 & $* 8$ \\
\hline & $A$ & 0.1 & 0 & & & & & & \\
\hline & B & 0.6 & 0 & & & & & & \\
\hline 7120 & & 69.6 & 1.8 & 5 & 73 & 44 & 51 & 48.12 & $* 9$ \\
\hline \multirow[t]{3}{*}{7140} & & 13.8 & 0.8 & 10 & 15 & 10 & 14 & 12.55 & $* 10$ \\
\hline & $A$ & 1.3 & 0.2 & & & & & & \\
\hline & B & 12.5 & 0.6 & & & & & & \\
\hline 7150 & & 2.2 & 0 & 25 & 2.9 & -8 & 3.2 & 2.4 & \\
\hline 7210 & & 0.6 & 1.8 & 10 & 0.7 & -35 & 1.02 & 0.92 & $* 4$ \\
\hline 7220 & & 0.008 & 0 & & 0.0 & 167 & 0.003 & 0.003 & \\
\hline 7230 & & 0.073 & 0 & 25 & 0.1 & -12 & 0.11 & 0.077 & $* 5$ \\
\hline 9110 & & 3.7 & 0 & & 3.7 & -24 & 4.9 & 4.92 & \\
\hline 9120 & & 71 & 1.8 & 43 & 125 & 1 & 123 & 70.68 & $*_{1}$ \\
\hline \multirow[t]{3}{*}{9160} & & 8.72 & 0.7 & & 8.7 & -38 & 14 & & \\
\hline & $A$ & 0.72 & 0.1 & 80 & & & 4.2 & 0.84 & $*_{1}$ \\
\hline & B & 8 & 0.6 & 12 & & & 9.8 & 7.68 & $*_{1}$ \\
\hline 9190 & & 20.7 & 2.3 & 20 & 26 & -11 & 29 & 23 & $*_{1}$ \\
\hline 91D0 & & 10.6 & 6.1 & 30 & 15 & 87 & 8.1 & 5.63 & $* 1$ \\
\hline \multirow[t]{4}{*}{$91 \mathrm{E} 0$} & & 35.3 & 2.5 & & 35 & -48 & 68 & 33.26 & \\
\hline & A & 25.4 & 1.1 & & & & 50 & 50 & $*_{1}$ \\
\hline & B & 0.4 & 0.4 & 51 & & & & & \\
\hline & C & 9.2 & 1 & 50 & & & 18 & 9 & $* 1$ \\
\hline 91F0 & & 0.3 & 0 & 33 & 0.4 & -50 & 0.9 & 0.61 & $*_{1}$ \\
\hline
\end{tabular}




\section{Opmerkingen:}

*1 het percentage buiten HR is berekend; staat niet in SDF-rapport

*2 In habitatkaart ontbreekt waarschijnlijk de Noordzeekustzone

*3 Som zou 0.26 moeten zijn

*4 In SDF-rapport staat foutief $1.15 \mathrm{~km} 2$

*5 Berekening in SDF-rapprot klopt niet

*6 In de EU rapportage van 2013 is een oppervlakte van $36 \mathrm{~km} 2$ aangegeven

*7 In de EU rapportage van 2013 is een oppervlakte van $9 \mathrm{~km} 2$ aangegeven

*8 In de EU rapportage van 2013 is een oppervlakte van $1.3 \mathrm{~km} 2$ aangegeven

*9 In de EU rapportage van 2013 is een oppervlakte van $52 \mathrm{~km} 2$ aangegeven

*10 In de EU rapportage van 2013 is een oppervlakte van $15 \mathrm{~km} 2$ aangegeven

*11 In de EU rapportage van 2013 is een oppervlakte van 931 km2 aangegeven 



\section{Bijlage 6 Schema beoordeling S\&F}

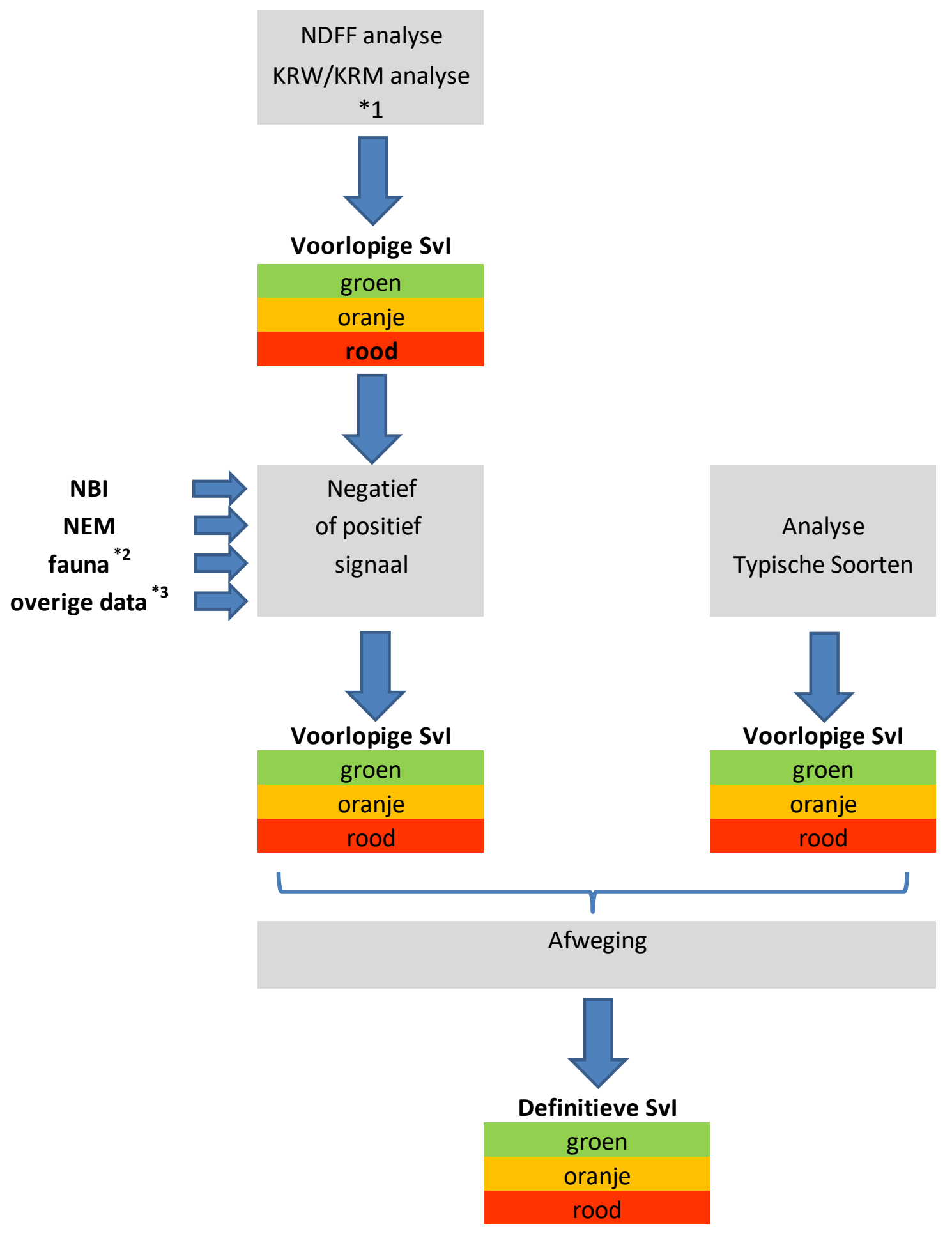

TOELICHTING

Zie paragraaf 4.3.2 en 4.4.1 voor een toelichting op respectievelijk de KRW/KRM analyse en de NDFF analyse, en paragrafen 4.5.2 en 4.5.3 voor een toelichting op de NEM en NBI methode.

VOETNOTEN

*1 Voor de habitattypen 4010, 9160 en 91E0 zijn de analyses uitgevoerd op basis van subtypen, die onderling zijn gewogen. Voor habitattype 3260 is alleen voor subtype A de NDFF-methode gevolgd. 
*2 Indien informatie over fauna doorslaggevend is geweest bij de beoordeling van Structuur \& Functie dan is dit in het opmerkingenveld 10.8 gemeld.

*3 Op basis van allerlei andere informatie kan een voorlopige beoordeling worden bijgesteld; in dit geval moet specifiek vermeld worden in de rapportage welke gegevens (met verwijzing naar bronnen) gebruikt zijn om de voorlopige beoordeling bij te stellen.

Het behoud van de ecologische variatie van een habitattype is een belangrijk onderdeel van de habitatrichtlijn. Het is als eigen criterium meegewogen in de beoordeling van Structuur \& Functie, met als uitgangspunt dat alle subtypen voldoende vertegenwoordigd moeten zijn binnen het verspreidingsgebied; hiervoor zouden kwantitatieve criteria kunnen worden opgesteld, bijvoorbeeld gekoppeld aan de referentiewaarde van het verspreidingsgebied. Vooralsnog zijn dergelijke criteria er nog niet, en vindt de beoordeling plaats op basis van expert-kennis. Er is momenteel geen habitattype dat op basis van dit criterium slechter scoort dan op basis van andere gegevens. 


\section{Bijlage 7 Karakteristieke soorten vaatplanten en mossen per habitattype}

Karakteristieke soorten van een habitattype (C1-soortenen) worden hier gedefinieerd als soorten die binnen het verspreidingsgebied van het habitattype in Nederland (op de schaal van fysisch-geografische regio's, FGRs) een binding hebben met het habitattype, d.w.z. vooral voorkomen in dat habitattype. Een soort kan dus karakteristiek zijn voor meerdere habitattypen als deze voorkomen in verschillende FGRs, zoals lavendelheide voor hoogveen (FGR Hogere zandgronden) en moerasheide (FGR Laagveengebied).

De lijst is in eerste instantie opgesteld uit bestaande lijsten van 1) typische soorten van habitattypen, 2) kwaliteitssoorten van beheertypen en 3) zogenaamde SDF-soorten (Janssen et al. 2014). Ook is een lijst opgesteld van relevante FGRs voor het verspreidingsgebied per habitattype. De soortenlijst is vervolgens kritisch beoordeeld ten aanzien van binding van soorten aan habitattype binnen relevante FGRs. Deze beoordeling is uitgevoerd door Rienk-Jan Bijlsma, Eddy Weeda en John Janssen, voor vaatplanten, mossen, korstmossen, kranswieren en bepaalde groepen paddenstoelen. Soms zijn soorten toegevoegd die ontbraken op genoemde basislijsten; soms zijn typische soorten niet opgenomen als karakteristieke soort van het betreffende habitattype vanwege onvoldoende binding.

Voor de rapportage is alleen gebruikgemaakt van de lijst vaatplanten en mossen omdat voor die soortgroepen trends konden worden berekend door het CBS. Deze soortenlijst samen met de lijst FGRs per habitattype kan als Excel-bestand "KarakteristiekeSoortenHabitatttypen2019" worden opgevraagd bij Rienk-Jan Bijlsma (rienkjan.bijlsma@wur.nl). 



\section{Bijlage 8 Resultaten S\&F: NDFF-methode, Typische soorten en NBI- methode}

\section{NDFF-methode}

Zie §4.4.1 voor achtergrond en werkwijze van de 'NDFF-methode'. Het eindoordeel Structuur \& Functie excl. Typische soorten volgens de NDFF-methode is afzonderlijk bepaald voor relatief soortenrijke habitathoofdtypen en -subtypen. Deze scores worden in tabel B8.1 naast elkaar gepresenteerd. Ter vergelijking van de huidige rapportage (SF23) is de nieuw ontwikkelde methode ook toegepast op data van de vorige rapportageperiode (SF12). NB H91E0_D betreft H91E0_A + H91E0_B (zacht- en hardhoutooibossen).

Tabel B8.1 Uitkomsten Structuur \& Functie excl. Typische soorten volgens de NDFF-methode, voor de vorige (SF12) en huidige (SF23) rapportageperiode.

\begin{tabular}{|c|c|c|c|c|c|}
\hline HCODE & S\&F12 & S\&F23 & HCODE & S\&F12 & S\&F23 \\
\hline H1310_B & U2 & U2 & H1310_B & U2 & U2 \\
\hline $\mathrm{H} 2120$ & U1 & U1 & H2120 & U1 & U1 \\
\hline \multirow[t]{3}{*}{$\mathrm{H} 2130$} & U2 & U1 & H2130_A & U1 & U1 \\
\hline & & & H2130_B & U2 & U2 \\
\hline & & & H2130_C & U1 & U1 \\
\hline \multirow[t]{3}{*}{$\mathrm{H} 2180$} & U2 & U1 & H2180_A & U1 & U1 \\
\hline & & & H2180_B & U2 & U1 \\
\hline & & & H2180_C & U2 & U2 \\
\hline \multirow[t]{4}{*}{$\mathrm{H} 2190$} & U1 & U2 & H2190_A & U1 & U1 \\
\hline & & & H2190_B & U1 & U2 \\
\hline & & & H2190_C & U1 & U2 \\
\hline & & & H2190_D & U1 & U1 \\
\hline H2330 & U2 & U1 & H2330 & U2 & U1 \\
\hline H3130 & U2 & U2 & H3130 & U2 & U2 \\
\hline H3150 & U1 & U2 & H3150 & U1 & U2 \\
\hline H3160 & U2 & U1 & H3160 & U2 & U1 \\
\hline H3260_A & U2 & U1 & H3260_A & U2 & U1 \\
\hline H3260_B & U2 & U1 & H3260_B & U2 & U1 \\
\hline H3270 & U2 & U1 & H3270 & U2 & U1 \\
\hline H4010_A & U2 & U1 & H4010_A & U2 & U1 \\
\hline H4010_B & U1 & U2 & H4010_B & U1 & U2 \\
\hline $\mathrm{H} 4030$ & U2 & U1 & H4030 & U2 & U1 \\
\hline $\mathrm{H} 6110$ & U2 & U1 & H6110 & U2 & U1 \\
\hline $\mathrm{H} 6120$ & U2 & U2 & H6120 & U2 & U2 \\
\hline $\mathrm{H} 6210$ & U2 & U1 & H6210 & U2 & U1 \\
\hline $\mathrm{H} 6230$ & U1 & U1 & H6230 & U1 & U1 \\
\hline $\mathrm{H} 6410$ & U1 & U1 & H6410 & U1 & U1 \\
\hline \multirow[t]{3}{*}{ H6430 } & U1 & U1 & H6430_A & U1 & U1 \\
\hline & & & H6430_B & U1 & U2 \\
\hline & & & H6430_C & U1 & U1 \\
\hline $\mathrm{H} 6510$ & U2 & U2 & H6510_A & U2 & U2 \\
\hline
\end{tabular}




\begin{tabular}{|l|c|l|l|l|l|}
\hline HCODE & S\&F12 & S\&F23 & HCODE & S\&F12 & S\&F23 \\
\hline H7110 & & & H6510_B & U1 & U2 \\
\hline & U2 & U2 & H7110_A & U2 & U2 \\
\hline H7120 & U1 & U2 & H7120 & U1 & U2 \\
\hline H7140 & U1 & U1 & H7140_A & U1 & U2 \\
\hline & & & H7140_B & U1 & U1 \\
\hline H7230 & U2 & U2 & H7230 & U2 & U2 \\
\hline H9110 & U2 & U2 & H9110 & U2 & U2 \\
\hline H9120 & U2 & U1 & H9120 & U2 & U1 \\
\hline H9160_A & U2 & U2 & H9160_A & U2 & U2 \\
\hline H9160_B & U2 & U1 & H9160_B & U2 & U1 \\
\hline H9190 & U2 & U2 & H9190 & U2 & U2 \\
\hline H91D0 & U1 & U1 & H91D0 & U1 & U1 \\
\hline H91E0_C & U2 & U2 & H91E0_C & U2 & U2 \\
\hline H91E0_D & U2 & U2 & H91E0_D & U2 & U2 \\
\hline H91F0 & U1 & U1 & H91F0 & U1 & U1 \\
\hline
\end{tabular}

\section{Typische soorten}

Zie $§ 4.4 .2$ voor achtergrond en werkwijze bepaling stand van instandhouding typische soorten. Tabel B8.2 geeft het eindoordeel voor habitattypen met tenminste 12 typische soorten (NSPEC). De aandelen per categorie staat van instandhouding (\%FV, \%U1 en \%U2) zijn ook opgenomen.

Tabel B8.2 Uitkomsten Structuur \& Functie Typische soorten voor de huidige rapportageperiode.

\begin{tabular}{|l|r|r|r|r|c|}
\hline HCODE & NSPEC & \%FV & \%U1 & \%U2 & S\&F TS \\
\hline H1110_A & 16 & 69 & 31 & 0 & U1 \\
\hline H1110_BC & 34 & 56 & 44 & 0 & U1 \\
\hline H1130 & 18 & 67 & 22 & 11 & U1 \\
\hline H1140_A & 11 & 64 & 18 & 18 & U1 \\
\hline H1140_B & 2 & 0 & 100 & 0 & U1 \\
\hline H1160 & 17 & 65 & 24 & 12 & U1 \\
\hline H1170 & 1 & 0 & 100 & 0 & U1 \\
\hline H1310 & 12 & 67 & 25 & 8 & U1 \\
\hline H1320 & 1 & 0 & 0 & 100 & U2 \\
\hline H1330 & 28 & 36 & 46 & 18 & U1 \\
\hline H2110 & 1 & 0 & 0 & 100 & U2 \\
\hline H2120 & 13 & 54 & 31 & 15 & U1 \\
\hline H2130 & 51 & 45 & 25 & 29 & U2 \\
\hline H2140 & 2 & 50 & 50 & 0 & U1 \\
\hline H2150 & 3 & 100 & 0 & 0 & FV \\
\hline H2160 & 2 & 50 & 50 & 0 & U1 \\
\hline H2170 & 2 & 0 & 50 & 50 & U2 \\
\hline H2180 & 5 & 100 & 0 & 0 & FV \\
\hline H2190 & 27 & 22 & 37 & 41 & U2 \\
\hline H2310 & 35 & 23 & 42 & U2 \\
\hline H2320 & 60 & 40 & 0 & U1 \\
\hline H2330 & 5 & 50 & 19 & 31 & U1 \\
\hline H3110 & 33 & 17 & 50 & U2 \\
\hline & & & & & \\
\hline
\end{tabular}




\begin{tabular}{|c|c|c|c|c|c|}
\hline HCODE & NSPEC & $\%$ FV & \%U1 & \%U2 & S\&F TS \\
\hline H3130 & 23 & 39 & 30 & 30 & U2 \\
\hline $\mathrm{H} 3140$ & 13 & 38 & 38 & 23 & U1 \\
\hline $\mathrm{H} 3150$ & 18 & 50 & 28 & 22 & U1 \\
\hline $\mathrm{H} 3160$ & 11 & 36 & 36 & 27 & U2 \\
\hline H3260_A & 18 & 33 & 33 & 33 & U2 \\
\hline H3260_B & 3 & 100 & 0 & 0 & $\mathrm{FV}$ \\
\hline $\mathrm{H} 3270$ & 9 & 78 & 22 & 0 & FV \\
\hline H4010_A & 13 & 23 & 62 & 15 & U1 \\
\hline H4010_B & 1 & 0 & 100 & 0 & U1 \\
\hline $\mathrm{H} 4030$ & 26 & 35 & 31 & 35 & U2 \\
\hline H5130 & 2 & 50 & 0 & 50 & U1 \\
\hline $\mathrm{H} 6110$ & 7 & 29 & 29 & 43 & U2 \\
\hline $\mathrm{H} 6120$ & 16 & 31 & 44 & 25 & U1 \\
\hline $\mathrm{H} 6130$ & 3 & 0 & 33 & 67 & U2 \\
\hline $\mathrm{H} 6210$ & 24 & 13 & 50 & 38 & U2 \\
\hline $\mathrm{H} 6230$ & 14 & 7 & 36 & 57 & U2 \\
\hline $\mathrm{H} 6410$ & 13 & 8 & 31 & 62 & U2 \\
\hline $\mathrm{H} 6430$ & 23 & 48 & 35 & 17 & U1 \\
\hline $\mathrm{H} 6510$ & 18 & 44 & 22 & 33 & U2 \\
\hline $\mathrm{H} 7110$ & 23 & 17 & 35 & 48 & U2 \\
\hline $\mathrm{H} 7120$ & 21 & 19 & 29 & 52 & U2 \\
\hline $\mathrm{H} 7140$ & 22 & 14 & 27 & 59 & U2 \\
\hline $\mathrm{H} 7150$ & 3 & 100 & 0 & 0 & $\mathrm{FV}$ \\
\hline $\mathrm{H} 7210$ & 1 & 100 & 0 & 0 & FV \\
\hline $\mathrm{H} 7220$ & 8 & 38 & 38 & 25 & U1 \\
\hline $\mathrm{H} 7230$ & 6 & 0 & 50 & 50 & U2 \\
\hline H9110 & 14 & 64 & 36 & 0 & U1 \\
\hline $\mathrm{H} 9120$ & 8 & 88 & 13 & 0 & $\mathrm{FV}$ \\
\hline H9160_A & 13 & 69 & 23 & 8 & U1 \\
\hline H9160_B & 37 & 43 & 24 & 32 & U2 \\
\hline H9190 & 9 & 89 & 11 & 0 & $\mathrm{FV}$ \\
\hline H91D0 & 5 & 40 & 60 & 0 & U1 \\
\hline H91E0_AB & 14 & 50 & 36 & 14 & U1 \\
\hline H91E0_C & 27 & 48 & 37 & 15 & U1 \\
\hline H91F0 & 4 & 75 & 25 & 0 & FV \\
\hline
\end{tabular}

\section{NBI-methode (bossen)}

Zie §4.6.3 voor achtergrond en werkwijze bepaling. De uitkomsten zijn opgenomen in tabel B8.3. 


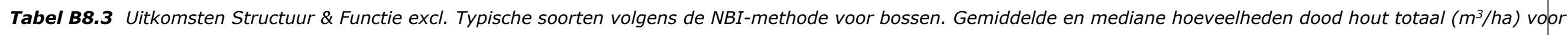
habitattypen in relevante landschappen, en afgeleide statistieken.

\begin{tabular}{|c|c|c|c|c|c|c|c|c|c|c|c|c|c|c|c|c|}
\hline \multirow{3}{*}{ Habitattype } & \multicolumn{6}{|c|}{ Voorraad dood hout ( $\left.\mathrm{m}^{3} / \mathrm{ha}\right)$} & \multirow{2}{*}{\multicolumn{2}{|c|}{$\begin{array}{c}\mathrm{p} \text {-value Wilcox } \\
\text { toets op } \\
\text { gemiddelde MFV } \\
\text { versus NBI }\end{array}$}} & \multicolumn{2}{|c|}{ Overall } & \multicolumn{6}{|c|}{ Aantal punten slecht/matig/goed } \\
\hline & \multicolumn{3}{|c|}{ MFV } & \multicolumn{3}{|c|}{ NBI } & & & \multirow[t]{2}{*}{$\begin{array}{c}\text { mean } \\
\text { NBI }\end{array}$} & \multirow[t]{2}{*}{$\begin{array}{c}\text { trend } \\
\text { MFV-NBI }\end{array}$} & \multicolumn{3}{|c|}{ MFV } & \multicolumn{3}{|c|}{ NBI } \\
\hline & כ & 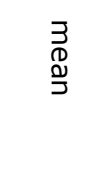 & 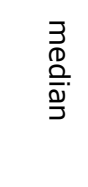 & כ & 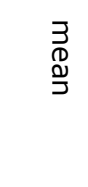 & 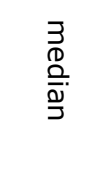 & 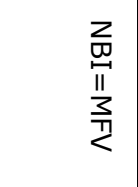 & 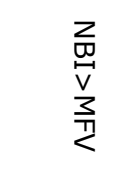 & & & 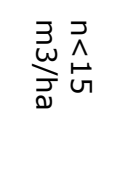 & 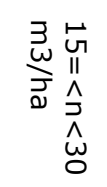 & 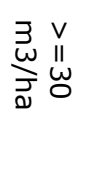 & 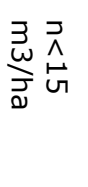 & 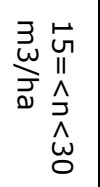 & 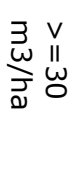 \\
\hline H2180 habkaart & 46 & 7.2 & 0.9 & 51 & 11.9 & 6.9 & 0.03 & 0.98 & U2 & positief & 37 & 7 & 2 & 31 & 11 & 5 \\
\hline H2180 habkaart + DU-extra & 111 & 6.4 & 0.2 & 116 & 14.1 & 1.8 & 0.04 & 0.98 & U2 & positief & 92 & 13 & 6 & 82 & 14 & 15 \\
\hline H9110 habkaart & 6 & 11.7 & 11.1 & 6 & 3.2 & 0.0 & 0.11 & 0.06 & $\mathrm{U} 2$ & stabiel & 4 & 2 & 0 & 6 & 0 & 0 \\
\hline H9110 habkaart + HL-extra & 8 & 13.5 & 15.8 & 8 & 6.3 & 2.3 & 0.15 & 0.08 & U2 & stabiel & 4 & 4 & 0 & 7 & 1 & 0 \\
\hline H9120 habkaart & 75 & 12.2 & 5.8 & 79 & 22.6 & 12.1 & 0.04 & 0.98 & U1 & positief & 51 & 16 & 8 & 40 & 16 & 20 \\
\hline H9190 habkaart & 32 & 11.1 & 6.1 & 33 & 20.5 & 14.0 & 0.05 & 0.98 & U1 & positief & 25 & 3 & 4 & 16 & 7 & 9 \\
\hline H9120+H9190 habkaart & 107 & 11.9 & 5.8 & 112 & 22.0 & 12.7 & 0.00 & 1.00 & U1 & positief & 76 & 19 & 12 & 56 & 23 & 29 \\
\hline $\begin{array}{l}\text { H9120+H9190 habkaart + } \\
\text { HZ-TMK-extra }\end{array}$ & 957 & 9.1 & 2.5 & 958 & 13.1 & 4.9 & 0.00 & 1.00 & $\mathrm{U} 2$ & positief & 760 & 121 & 76 & 669 & 147 & 120 \\
\hline $\begin{array}{l}\text { H9120+H9190 habkaart + } \\
\text { HZ-extra }\end{array}$ & 2325 & 7.9 & 2.2 & 2326 & 12.3 & 4.5 & 0.00 & 1.00 & $\mathrm{U} 2$ & positief & 1919 & 264 & 142 & 1674 & 320 & 265 \\
\hline H9160B habkaart & 12 & 15.3 & 12.3 & 11 & 24.8 & 9.3 & 0.88 & 0.59 & U1 & stabiel & 8 & 2 & 2 & 6 & 2 & 3 \\
\hline
\end{tabular}




\section{Verschenen documenten in de reeks Technical reports van de Wettelijke Onderzoekstaken Natuur}

\& Milieu

146 Arets, E.J.M.M., J.W.H van der Kolk, G.M. Hengeveld, J.P. Lesschen, H. Kramer, P.J. Kuikman \& M.J. Schelhaas (2019). Greenhouse gas reporting of the LULUCF sector in the Netherlands. Methodological background, update 2019.

147 Bruggen, C. van, A. Bannink, C.M. Groenestein, J.F.M Huijsmans, L.A. Lagerwerf, H.H. Luesink, S.M. van der Sluis, G.L. Velthof \& J. Vonk (2019). Emissies naar lucht uit de landbouw in 2017. Berekeningen met het model NEMA.

148 Lagerwerf, L.A., A. Bannink, C. van Bruggen, C.M. Groenestein, J.F.M. Huijsmans, J.W.H. van der Kolk, H.H. Luesink, S.M. van der Sluis, G.L. Velthof \& J. Vonk (2019). Methodology for estimating emissions from agriculture in the Netherlands. Calculations of CH4, NH3, N2O, NOX, NMVOC, PM1O, PM2.5 and $\mathrm{CO} 2$ with the National Emission Model for Agriculture (NEMA) - update 2019

149 Bakker, G., M. Heinen, H.P.A. Gooren, W.J.M. de Groot, F.B.T. Assinck \& E.W.J. Hummelink (2019). Hydrofysische gegevens van de bodem in de Basisregistratie Ondergrond (BRO) en het Bodemkundig Informatie Systeem (BIS); Update 2018.

150 IJsseldijk, L.L., M.J.L. Kik, \& A. Gröne (2019). Postmortaal onderzoek van bruinvissen (Phocoena phocoena) uit Nederlandse wateren, 2018. Biologische gegevens, gezondheidsstatus en doodsoorzaken.

151 Daamen, W.P., A.P.P.M. Clerkx \& M.J. Schelhaas (2019). Veldinstructie Zevende Nederlandse Bosinventarisatie (2017-2021); Versie 2.0.

152 Bikker, P., L.B. Šebek, C. van Bruggen \& O. Oenema (2019). Stikstof- en fosfaatexcretie van gangbaar en biologisch gehouden landbouwhuisdieren. Herziening excretieforfaits Meststoffenwet 2019.

153 Berg, F. van den, H. Baveco \& E.L. Wipfler (2019) User manual for SAFE (Select Application date For Evaluation) to support the use of the GEM scenarios for cultivations in glasshouses; Version 1.1

154 Os, J. van, L.J.J. Jeurissen en H.H. Ellen (2019). Rekenregels pluimvee voor de Landbouwtelling; Verantwoording van het gebruik van het Identificatie- \& Registratiesysteem.

155 Brouwer, F. \& D.J.J. Walvoort (2019). Basisregistratie Ondergrond (BRO) - Actualisatie bodemkaart; Herkartering van de veengebieden in Eemland

156 Sanders, M.E., R.J.H.G. Henkens \& D.M.E. Slijkerman (2019). Convention on Biological Diversity; Sixth National Report of the Kingdom of the Netherlands.

157 Kuiters, A.T., G.A. de Groot, D.R. Lammertsma, H.A.H. Jansman, J. Bovenschen, M.C. Boerwinkel \&
M. Laar (2019). Genetische monitoring van de Nederlandse otterpopulatie; Ontwikkeling van populatieomvang en genetische status 2018/2019.

158 Sanders, M.E. \& H.A.M. Meeuwsen (2019). Basisbestand Natuur en Landschap.

159 Visser, T., H.A.M Meeuwsen \& Th.C.P. Melman (2019). MNP-(Model for Nature Policy) Agrarisch; Uitwerking voor scenario's uit de Natuurverkenning 2020.

160 Jong, A. de, A. Poot \& P.I. Adriaanse (2019). Impact analysis for the purpose of the introduction of DROPLET version 1.3.2.

161 Westerink, J., T.A. de Boer, M. Pleijte \& R.A.M. Schrijver (2019). Kan een goede boer natuurinclusief zijn?; De rol van culturele normen in een beweging richting natuurinclusieve landbouw.

162 Buijs, A.E., F.G. Boonstra (2020). Natuurbeleid betwist; Visies op legitimiteit en natuurbeleid.

163 Haas, W. de, J.L.M. Donders, T.J.M. Mattijssen (2019). Natuur in conflict; Botsende waarden, waarheden en belangen in het natuurbeheer.

164 Berg, F. van den, A. Tiktak, D. van Kraalingen \& J.J.T.I. Boesten (2019). User manual for FOCUSPEARL version 5.5.5.

165 Glorius, S.T., A. Meijboom, J. Schop \& J.T. van der Wal (2019). Ontwikkeling van enkele droogvallende mosselbanken in de Nederlandse Waddenzee; situatie 2018

166 Pedroli, B, During, R. (2019). De paradox van een maakbare natuur - ingebakken en omstreden; Betekenis culturele identiteit voor draagvlak natuurbeleid en -beheer.

167 Walvoort, D.J.J., M. Knotters, F.M. van Egmond (2019). Interpolatie, aggregatie en desaggregatie van ruimtelijke bodemgegevens in de Basisregistratie Ondergrond (BRO).

168 Arets, E.J.M.M., J.W.H van der Kolk, G.M. Hengeveld, J.P. Lesschen, H. Kramer, P.J. Kuikman \& M.J. Schelhaas (2020). Greenhouse gas reporting of the LULUCF sector in the Netherlands. Methodological background, update 2020.

170 Bos-Groenendijk, G.I., C.A.M van Swaay (2020). Habitatrichtlijnrapportage 2019: Annex B Habitatrichtlijnsoorten; Achtergronddocument.

171 Janssen, J.A.M. (red.), R.J. Bijlsma (red.), G.H.P. Arts, M.J. Baptist, S.M. Hennekens, B. de Knegt, T. van der Meij, J.H.J. Schaminée, A.J. van Strien, S. Wijnhoven, T.J.W. Ysebaert (2020). Habitatrichtlijnrapportage 2019: Annex D Habitattypen. Achtergronddocument. 


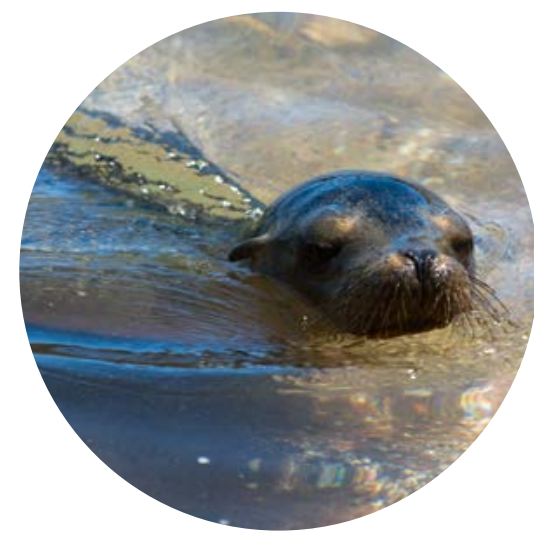

Thema Informatievoorziening Natuur Wettelijke Onderzoekstaken Natuur \& Milieu

P.O. Box 47

6700 AA Wageningen

T (0317) 485471

E info.wnm@wur.nl

ISSN 2352-2739

www.wur.nl/wotnatuurenmilieu

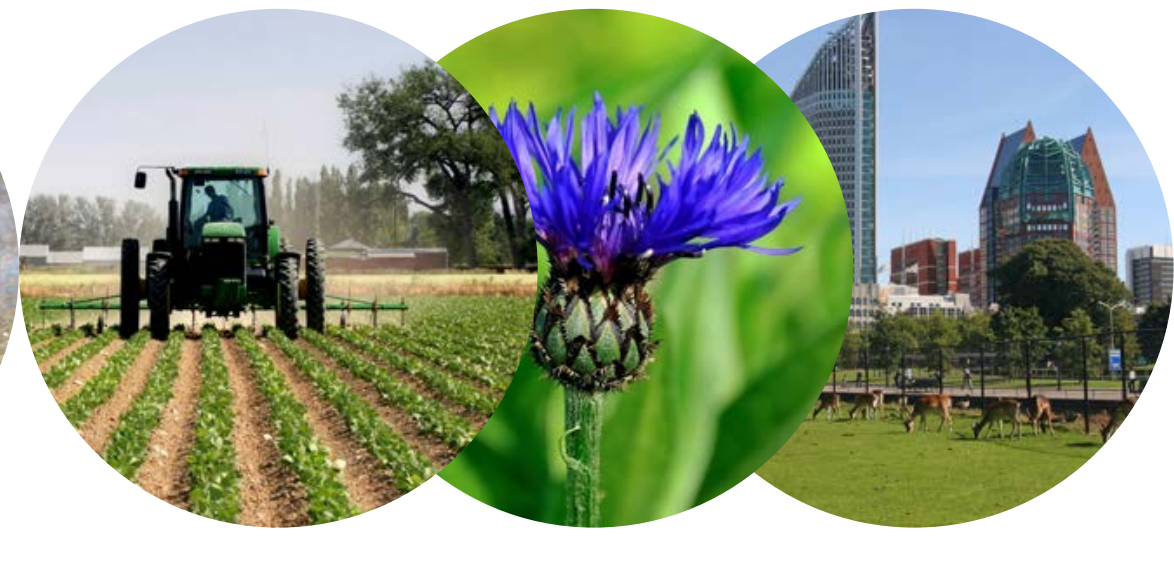

The mission of Wageningen University and Research is "To explore the potential of nature to improve the quality of life". Under the banner Wageningen University \& Research, Wageningen University and the specialised research institutes of the Wageningen Research Foundation have joined forces in contributing to finding solutions to important questions in the domain of healthy food and living environment. With its roughly 30 branches, 5,000 employees and 10,000 students, Wageningen University \& Research is one of the leading organisations in its domain. The unique Wageningen approach lies in its integrated approach to issues and the collaboration between different disciplines.

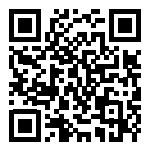

